UNIVERSIDADE DE SÃO PAULO-USP

ESCOLA DE ENGENHARIA DE SÃO CARLOS-EESC

DEPARTAMENTO DE HIDRÁULICA E SANEAMENTO-SHS

LABORATÓRIO DE PROCESSOS BIOLÓGICOS-LPB

Jorge Luis Rodrigues Pantoja Filho

Remoção de Matéria Orgânica Carbonácea e Nitrogênio em Reator Aeróbio-Anóxico de Leito Fixo (RAALF) Aplicado ao Pós-

Tratamento de Efluente de Reator Anaeróbio 

Jorge Luis Rodrigues Pantoja Filho

\section{Remoção de Matéria Orgânica Carbonácea e Nitrogênio em Reator Aeróbio-Anóxico de Leito Fixo (RAALF) Aplicado ao Pós- Tratamento de Efluente de Reator Anaeróbio}

Tese apresentada à Escola de Engenharia de São Carlos da Universidade de São Paulo, como parte dos requisitos necessários para a obtenção do título de Doutor em Ciências (Área de Concentração: Hidráulica e Saneamento)

Orientador: Prof. Tit. Eugenio Foresti 



\section{AUTORIZO A REPRODUÇÃO E DIVULGAÇÃO TOTAL OU PARCIAL DESTE TRABALHO, POR QUALQUER MEIO CONVENCIONAL OU ELETRÔNICO, PARA FINS DE ESTUDO E PESQUISA, DESDE QUE CITADA A FONTE.}

Ficha catalográfica preparada pela Seção de Tratamento da Informação do Serviço de Biblioteca - EESC/USP

\footnotetext{
Pantoja Filho, Jorge Luis Rodrigues
P198r Remoção de matéria orgânica carbonácea e nitrogênio em reator aeróbio-anóxico de leito fixo (RAALF) aplicado ao pós-tratamento de efluente de reator anaeróbio / Jorge Luis Rodrigues Pantoja Filho; orientador Eugenio Foresti. -- São Carlos, 2011.
}

Tese (Doutorado-Programa de Pós-Graduação e Área de Concentração em Hidráulica e Saneamento) -- Escola de Engenharia de São Carlos da Universidade de São Paulo, 2011 .

1. Esgoto sanitário. 2. Pós-tratamento. 3. RAALF. 4. Nitrificação. 5. Desnitrificação. 6. Biogás. I. Título. 



\section{FOLHA DE JULGAMENTO}

Candidato: Engenheiro JORGE LUIS RODRIGUES PANTOJA FILHO

Título da tese: Remoçăo de matéria orgânica carbonácia e nitrogênio em reator aeróbioanóxio de leito fixo (RAALF) aplicado ao pós-tratamento de efluente de reator anaeróbio.

Data da defesa: 22/07/2011:

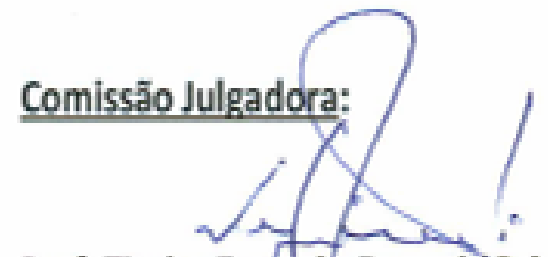

Resultado:

Prof. Titular Eugenio Foresti (Orientador)

APROVAAO

(Escola de Engenharia de São Carlos/EESC)

Prof. Associado Marcelo Zaiat

(Escola de Engenharia de São Carlos/EESC)
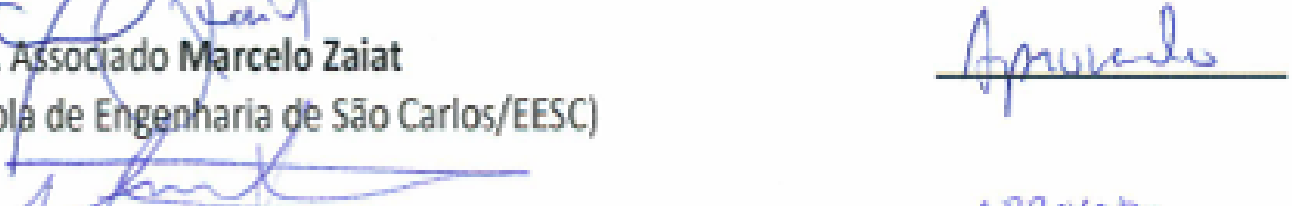

Prof. Dr. Marcelo Loureiro Garcia-

APROVADO

(Universidade Estadual Paulista "Júlio de Mesquita Filho"/UNESP/campus de Rio Claro)

Prof. Dr, Carlos Augusto de Lemos Chernicharo

APLONAOD

(Universidade Federal de Minas Gerais/UFMG)

Prof?. Dra, Savia Galdazza dos Santos Pessoa

APRONADO

(Universidade Federal de Pernambuco/UFPE)

Coordenador do Programa de Pós-Graduação em Engenharia Hidráulica e Saneamento: Prof. Titular Edson Cezar Wendland 

Para toda minha familia:

Obrigado pelo apoio e pela generosidade. 



\section{AGRADECIMENTOS}

A minha família. Muito obrigado pelo apoio e pela generosidade.

Ao Professor Eugenio Foresti, pela sempre prestimosa orientação, pela confiança e generosidade. Uma palavra o define: Mestre!

Aos Professores Marcelo Zaiat e José Alberto Domingues Rodrigues pela participação na banca de qualificação deste trabalho e pela conversas sempre oportunas e descontraídas.

Aos funcionários do Departamento de Hidráulica e Saneamento pelos serviços prestados durante todo o período de pós-graduação.

Aos colegas do Laboratório de Processos Biológicos, em especial aos amigos Theo Souza, Gustavo Mockaitis e Guilherme Peixoto.

Ao Oscar, pela confecção dos reatores.

Ao Instituto de Física de São Carlos, representado aqui pela pessoa do Sr. Nelson Gallo, pelas análises de microscopia eletrônica de varredura e de EDX.

À Dra. Eloiza Pozzi e à doutoranda Débora Fonseca pela ajuda com as análises microbiológicas.

Aos Professores que compõem a banca avaliadora deste trabalho.

À Escola de Engenharia de São Carlos da Universidade de São Paulo por ser um centro de excelência acadêmica e proporcionar aos seus alunos condições para a aquisição do conhecimento.

À FAPESP pelo financiamento do Seminário Temático.

À CAPES e ao CNPq pelo financiamento da bolsa de doutorado.

À todos aqueles que, de forma direta ou indireta, contribuíram para que este trabalho tenha sido realizado.

$\grave{A}$ todos aqueles que contribuem de alguma forma para o engrandecimento do arcabouço intelectual da humanidade. 

"The beautiful thing about learning is that nobody can take it away from you."

B. B. King

"And no one show us to the land And no one knows the wheres or whys But something stares and something tries And starts to climb towards the light Strangers passing in the street By chance two separate glances meet And I am you and what I see is me."

'Echoes', Pink Floyd 



\section{RESUMO}

\section{PANTOJA FILHO, J.L.R. (2011) Remoção de Matéria Orgânica Carbonácea e Nitrogênio em}

\section{Reator Aeróbio-Anóxico de Leito Fixo (RAALF) Aplicado ao Pós-Tratamento de Efluente de}

Reator Anaeróbio. Tese (Doutorado) - Escola de Engenharia de São Carlos, Universidade de São Paulo, São Carlos, 2011.

O presente trabalho apresenta o Reator Aeróbio-Anóxico de Leito Fixo (RAALF), constituído de duas câmaras sobrepostas, como uma alternativa ao pós-tratamento de efluentes de reatores anaeróbios com vistas à remoção de matéria orgânica carbonácea e nitrogênio. Como material suporte, foram utilizados cubos de espuma de poliuretano com aresta de $5 \mathrm{~mm}$. Foram realizados ensaios de caracterização hidrodinâmica no RAALF para obtenção do padrão de escoamento. Também foi verificada a viabilidade da utilização de biogás como doador de elétrons para a desnitrificação. Avaliou-se a influência da variação do tempo de detenção hidráulica e da diferente composição e concentração biogás do nos processos. O RAALF foi operado a uma temperatura de $30 \pm 2^{\circ} \mathrm{C}$. Os resultados obtidos a partir dos estudos hidrodinâmicos indicaram que o escoamento do reator tende a pistonado. A nova configuração de reator permitiu a ocorrência dos processos de interesse, seja remoção de matéria orgânica carbonácea (com eficiências de até 98\%), seja remoção de nitrogênio via nitrificaçãodesnitrificação (com eficiências acima de 90\%). A utilização de biogás na desnitrificação mostrou-se viável e a taxa de desnitrificação foi maior na sub-condição 2.2 (média de $178 \pm 43 \mathrm{~g}-\mathrm{N} \mathrm{m}^{-3}$ dia $^{-1}$ ), etapa na qual o doador sulfeto de hidrogênio foi fornecido em alta concentração $\left(50 \mathrm{gm}^{3}\right)$. Foi possível detectar intermediário (metanol) a partir da oxidação parcial do metano, ainda que de forma inconstante. Resultados de atividade desnitrificante e número mais provável evidenciaram a coexistência da desnitrificação autotrófica e heterotrófica na câmara anóxica. O reator mostrou capacidade adicional como um sistema de tratamento de gases, atingindo eficiência de remoção de $100 \%$ para o $\mathrm{H}_{2} \mathrm{~S}$ e acima de $60 \%$ para o $\mathrm{CH}_{4}$. De maneira geral, os resultados demonstram o potencial do RAALF como alternativa para pós-tratamento de esgoto sanitário de efluentes de reatores anaeróbios.

Palavras chave: pós-tratamento, RAALF, nitrificação, desnitrificação, biogás. 


\begin{abstract}
PANTOJA FILHO, J.L.R. (2011) Removal of Carbonaceous Organic Matter and Nitrogen in an Aerobic-Anoxic Fix Bed Reactor (AAFBR) Applied to the Tertiary Treatment of Domestic Wastewater. Ph.D. Thesis - Sao Carlos School of Engineering, University of Sao Paulo, São Carlos, 2011.
\end{abstract}

This work presents the Aerobic-Anoxic Fix Bed Reactor (AAFBR), with superimposed chambers, as an alternative concerning the post-treatment of anaerobic reactors effluents aiming the removal of carbonaceous organic matter and nitrogen. Polyurethane foam cubic matrices $(5 \mathrm{~mm})$ were used packing material. Hydrodynamic essays were carried out in order to obtain the flow pattern and to verify the influence of air bubbles on the behavior of liquid flow. The hydrogen sulfide and methane (synthetic biogas) were evaluated as electron donors to denitrification. The influence of both hydraulic retention time (down-flow velocity) and the concentration of gases from the synthetic mixture were evaluated. The main performance parameters were evaluated by the hand of physico-chemical analysis, besides the observation of the microorganisms involved in the processes. AAFBR was operated under a temperature of $30 \pm 2^{\circ} \mathrm{C}$. The innovative reactor configuration enabled the occurrence of the processes aimed, such as carbonaceous organic matter removal (efficiencies higher than 90\%), or nitrogen via nitrification-denitrification (efficiencies higher than 90\%). Denitrification rates $\left(178 \pm 43 \mathrm{~g}-\mathrm{N} \mathrm{m}^{-3} \mathrm{dia}^{-1}\right)$ were higher during the condition 2.2, in which high concentrations of hydrogen sulfide $\left(50 \mathrm{gm}^{3}\right)$ were applied into the reactor. Methanol was the only intermediate detected from the partial oxidation of methane. Results obtained from the denitrifying activity and most probable number indicated the coexistence of both autotrophic and heterotrophic denitrification in the anoxic chamber. AAFBR showed additional ability as gas removal system, achieving global removal efficiencies of $100 \%$ for $\mathrm{H}_{2} \mathrm{~S}$ and above $60 \%$ for $\mathrm{CH}_{4}$. Overall, the results showed that AAFBR has potential to be used as an alternative for the tertiary treatment of wastewater.

Keywords: post-treament, AAFBR, nitrification, denitrification, biogas. 


\section{LISTA DE FIGURAS}

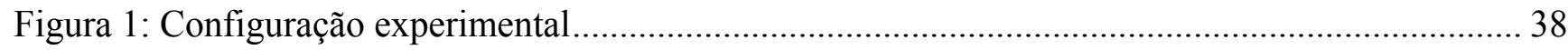

Figura 2: Esquema da configuração experimental utilizada nos ensaios hidrodinâmicos. ................... 41

Figura 3: Fotografia do RAALF durante um dos ensaios hidrodinâmicos .

Figura 4: Lodo aeróbio retirado de tanques de Lodos Ativados (cocos, bacilos e filamentos) (a) e Lodo anaeróbio retirado de Reator UASB tratando efluente de abatedouro de aves (preponderância de bacilos). 45

Figura 5: Curvas-resposta obtidas tendo o cloreto de sódio como traçador $(\theta \mathrm{h} \sim 1 \mathrm{~h}) \ldots \ldots \ldots \ldots \ldots \ldots \ldots \ldots . . . . . . . . . . .65$

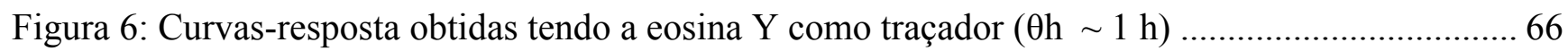

Figura 7: Curvas-resposta obtidas tendo o azul de bromofenol como traçador $(\theta \mathrm{h} \sim 1 \mathrm{~h})$.................. 66

Figura 8: Curvas-resposta obtidas tendo a dextrana azul como traçador $(\theta \mathrm{h} \sim 1 \mathrm{~h}) \ldots \ldots \ldots \ldots \ldots \ldots \ldots \ldots . . . . . . . . . . .67$

Figura 9: Curvas de distribuição do tempo de residência obtidas a partir dos ensaios realizados com dextrana azul e modelos teóricos N-CSTR e MDA (alta e baixa) ...................................................... 73

Figura 10: Dinâmica do nitrogênio amoniacal (Condição 1) ............................................................ 78

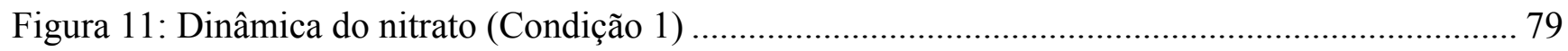

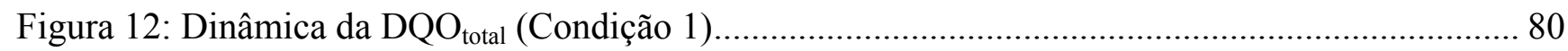

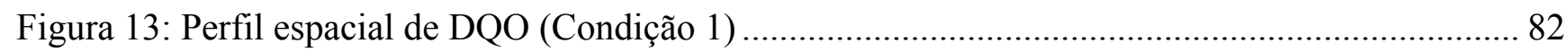

Figura 14: Perfil espacial de nitrogênio amoniacal e nitrato (Condição 1)........................................ 82

Figura 15: Valores da relação alcalinidade total/nitrogênio amoniacal (Condição 1) ......................... 83

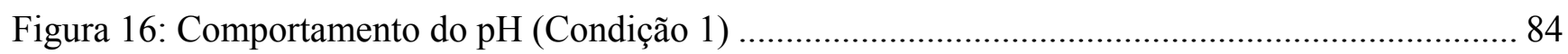

Figura 17: Comportamento das formas sulfurosas - Condição 1 .................................................... 85

Figura 18: Amostras retiradas do topo (a) e da base (b) da câmara aeróbia - Condição 1................... 86

Figura 19: Dinâmica da $\mathrm{DQO}_{\text {total }}$ - Condição 2 .............................................................................. 88

Figura 20: Eficiência de remoção de matéria orgânica carbonácea como função do $\theta$ h na câmara

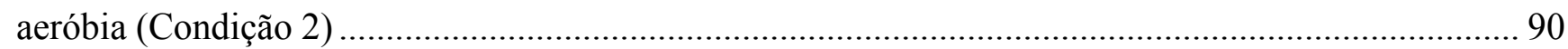

Figura 21: Perfil espacial de DQO - Condição 2 ............................................................................. 92

Figura 22: Dinâmica do nitrogênio amoniacal - Condição 2 .......................................................... 94

Figura 23: Dinâmica do nitrato - Condição 2 ............................................................................. 96

Figura 24: Perfil espacial de oxigênio dissolvido Aer: câmara aeróbia; Int: câmara intermediária; An:

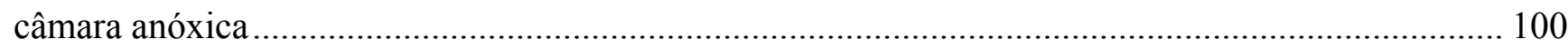

Figura 25: Perfil espacial de potencial de óxido redução - Condição 2 ............................................. 101

Figura 26: Esquema da dinâmica de consumo de sulfeto dentro do RAALF sob diferentes condições ambientais $\mathrm{O}$ sulfeto não utilizado na câmara anóxica no processo de redução de sulfato adentra a 
câmara aeróbia e é oxidado pelos organismos autotróficos aeróbios, evidenciando a atuação da câmara aeróbia como componente "polidor" no tratamento do biogás. 102

Figura 27: Comportamento das formas de enxofre - Condição 2

Figura 28: Perfis espaciais de concentração de sulfato - Condição 2 Aer: câmara aeróbia; Int: câmara intermediária; An: câmara anóxica.

Figura 29: Oxidação anaeróbia do metano associada à desnitrificação 108

Figura 30: Valores de concentração espaço-temporal de metanol na sub-condição 2.2 ..... 109

Figura 31: Amostras retiradas do topo (a) e da base (b) da câmara aeróbia - Condição 2. 111

Figura 32: Amostras retiradas do topo (a) e da base (b) da câmara anóxica - Condição 2. 112

Figura 33: Dinâmica da $\mathrm{DQO}_{\text {total }}$ - Condição 3

Figura 34: Perfil espacial de DQO - Condição 3

Figura 35: Dinâmica do $\mathrm{N}_{-} \mathrm{NH}_{4}^{+}$- Condição 3

Figura 36: Dinâmica do nitrato - Condição 3

Figura 37: Perfil espacial de OD - Condição 3

Figura 38: Perfil espacial do potencial de óxido-redução (pOR) - Condição 3

Figura 39: Perfil espacial de concentração de sulfato (Condição 3)

Figura 40: Morfologias observadas a partir de amostras retiradas do topo (a) e da base (b) da câmara aeróbia - Condição 3.

Figura 41: Amostras retiradas do topo e da base da câmara anóxica - Condição 3.

Figura 42: Comportamento da taxa de desnitrificação - Condição 2

Figura 43: Comportamento da taxa de desnitrificação - Condição 3

Figura 44: Eficiência de remoção dos gases sulfeto de hidrogênio e metano - Condição 2

Figura 45: Eficiência de remoção dos gases sulfeto de hidrogênio e metano - Condição 3

Figura 46: Balanço de massa para os compostos de nitrogênio durante a condição 2 de operação do 130

Figura 47: Balanço de massa para os compostos de nitrogênio durante a condição 3 de operação do RAALF. 


\section{LISTA DE TABELAS}

Tabela 1: Características construtivas do sistema UASB-RAALF .................................................... 37

Tabela 2: Características físicas da espuma de poliuretano ............................................................. 39

Tabela 3: Propriedades químicas dos doadores de elétrons utilizados para a desnitrificação ............... 40

Tabela 4: Composição média do biogás sintético ................................................................................. 41

Tabela 5: Características principais dos traçadores......................................................................... 42

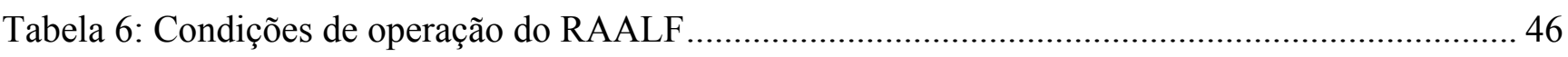

Tabela 7 : Parâmetros e freqüência de análises................................................................................. 48

Tabela 8: Definição das variáveis utilizadas para se obter a função de distribuição do tempo de

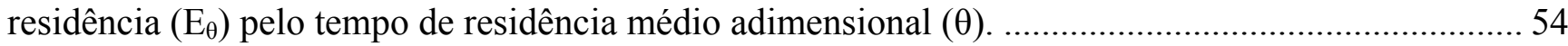

Tabela 9: Resultados obtidos para as condições experimentais no ensaio hidrodinâmico ..................... 68

Tabela 10: Coeficiente de correlação obtidos a partir do ajuste dos modelos teóricos às curves experimentais obtidos para cada experimento no RAALF, considerando um tempo de detenção hidráulica de 1 hora.

Tabela 11: Parâmetros dos modelos uniparamétricos obtidos param cada experimento no RAALF, considerando $\theta$ h de 1 hora. 72

Tabela 12: Parâmetros dos modelos matemáticos obtidos para cada experimento no RAALF,

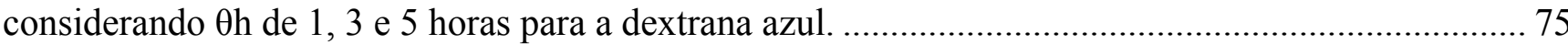

Tabela 13: Estatística descritiva das formas nitrogenadas (Condição 2) ........................................... 97

Tabela 14: Comportamento médio do pH e da alcalinidade (Condição 2) ........................................ 99

Tabela 15: Composição química da superfície do material suporte.................................................. 106

Tabela 17: Comportamento médio do pH e da alcalinidade - Condição 3 ........................................ 120

Tabela 17: Desempenho do RAALF enquanto sistema de tratamento de gases.............................. 129

Tabela 18: NMP de bactérias nitrificantes, desnitrificantes e metanotróficas de amostras retiradas das câmaras aeróbia e anoxica do RAALF durante a operação ............................................................ 132

Tabela 19: Atividade desnitrificante durante a operação do RAALF ............................................. 134 



\section{LISTA DE ABREVIATURAS, SIGLAS E SÍMBOLOS}

$\begin{array}{ll}\text { UASB } & \text { Reator Anaeróbio de Manta de Lodo } \\ \text { RAALF } & \text { Reator Aeróbio-Anóxico de Leito Fixo } \\ \text { ASBR } & \text { Anaerobic Sequencing Batch Reactor } \\ \text { RAHLF } & \text { Reator Anaeróbio Horizontal de Leito Fixo } \\ \text { RBC } & \text { Rotating Biological Contactors } \\ \text { SBR } & \text { Sequencing Batch Reactor } \\ \text { RMRLF } & \text { Reator Misto Radial de Leito Fixo } \\ \text { RAAHLF } & \text { Reator Aeróbio-Anaeróbio Horizontal de Leito Fixo } \\ \text { N-CSTR } & \text { Número de reatores em série } \\ \text { MDA } & \text { Modelo de dispersão axial }\end{array}$

Oh Tempo de detenção hidráulica [T]

$\mathrm{V}_{\mathrm{asc}} \quad$ Velocidade ascensional $[\mathrm{L}]\left[\mathrm{T}^{-1}\right]$

L Comprimento total [L]

$\mathrm{L}_{\mathrm{U}} \quad$ Comprimento útil [L]

D Diâmetro [L]

L/D Relação comprimento/diâmetro (Adimensional)

$\mathrm{L}_{\mathrm{U}} / \mathrm{D} \quad$ Relação comprimento útil/diâmetro (Adimensional)

V Volume total $\left[\mathrm{L}^{3}\right]$

$\mathrm{Vu} \quad$ Volume útil $\left[\mathrm{L}^{3}\right]$

$\mathrm{V}_{\text {aer }} \quad$ Volume da câmara aeróbia $\left[\mathrm{L}^{3}\right]$

$\mathrm{V}_{\mathrm{ano}} \quad$ Volume da câmara anóxica $\left[\mathrm{L}^{3}\right]$

$\lambda \quad$ Comprimento de onda [L]

$\mathrm{E}_{\theta} \quad$ Distribuição do tempo de residência (Adimensional) 
Tempo (adimensional)

tP

Tempo de pico $[\mathrm{T}]$

$\theta$ h

Tempo de residência médio [T]

$\mathrm{pH}$

Potencial hidrogeniônico

OD

Oxigênio dissolvido $[\mathrm{M}]\left[\mathrm{L}^{-3}\right]$ 


\section{SUMÁRIO}

$\begin{array}{ll}\text { 1. INTRODUÇÃO } & 01\end{array}$

$\begin{array}{lr}\text { 2. OBJETIVOS } & 07\end{array}$

$\begin{array}{ll}2.1 \text { OBJETIVO GERAL } & 09\end{array}$

2.2. OBJETIVOS ESPECÍFICOS 09

3. REVISÃO DE LITERATURA 11

3.1 CONSIDERAÇÕES INICIAIS 13

3.2 REMOÇÃO BIOLÓGICA DE NITROGÊNIO 13

3.2.1 Nitrificação 13

3.2.2 Desnitrificação 16

3.2.2.1 Desnitrificação convencional 16

$\begin{array}{ll}\text { 3.2.2.2 Doadores de elétrons alternativos na desnitrificação } & 17\end{array}$

$\begin{array}{ll}\text { 3.2.2.2.1 Compostos de enxofre } & 17\end{array}$

$\begin{array}{ll}\text { 3.2.2.2.2 Metano } & 20\end{array}$

3.2.3 Outros processos utilizados na remoção biológica de nitrogênio 24

3.3 REATORES COMBINADOS DE LEITO-FIXO APLICADOS AO PÓS-TRATAMENTO DE EFLUENTES DE REATORES ANAERÓBIOS 25

3.4 COMPORTAMENTO HIDRODINÂMICO 27

3.5 CONSIDERAÇÕES FINAIS 28

3.6 REFERÊNCIAS DO CAPÍTULO 29

4 MATERIAL E MÉTODOS 35

4.1 APARATO EXPERIMENTAL 37

$\begin{array}{ll}\text { 4.1.1 Configuração UASB-RAALF } & 37\end{array}$

$\begin{array}{ll}\text { 4.1.2 Material suporte } & 39\end{array}$

$\begin{array}{ll}\text { 4.1.3 Água residuária } & 39\end{array}$ 
4.1.4 Doadores de elétrons para a desnitrificação $\quad 40$

4.1.5 Caracterização hidrodinâmica $\quad 41$

4.2 PROCEDIMENTO EXPERIMENTAL 43

4.2.1 Microrganismos e inoculação $\quad 44$

4.2.2 Condições de operação $\quad 45$

$\begin{array}{ll}\text { 4.2.3 Monitoramento } & 47\end{array}$

4.2.3.1 Análises físico-químicas $\quad 47$

4.2.3.2 Metano e dióxido de carbono 49

$\begin{array}{ll}\text { 4.2.3.3 Sulfeto de hidrogênio } & 49\end{array}$

4.2.3.4 Alcoóis e ácidos voláteis $\quad 50$

4.2.4 Analise matemática do monitoramento $\quad 51$

4.2.4.1 Vazão de esgoto 51

4.2.4.2 Tempo de detenção hidráulico $\quad 51$

4.2.4.3 Eficiência de remoção de matéria orgânica carbonácea $\quad 51$

4.2.4.4 Eficiência de remoção de nitrogênio amoniacal 52

4.2.4.5 Eficiência de remoção de nitrato $\quad 52$

4.2.4.6 Eficiência de remoção de nitrito 52

4.2.4.7 Taxa de desnitrificação 53

4.2.4.8 Eficiência de remoção de gases

4.2.5 Análise matemática dos ensaios hidrodinâmicos $\quad 54$

4.2.6 Estudos microbiológicos $\quad 56$

4.2.6.1 Número mais provável $\quad 56$

4.2.6.1.1 Microrganismos nitrificantes $\quad 56$

4.2.6.1.2 Microrganismos desnitrificantes $\quad 56$

4.2.6.1.3 Microrganismos metanotróficos $\quad 57$

4.2.6.2 Visualização das morfologias $\quad 57$ 
$\begin{array}{ll}\text { 4.2.6.2.1 Microscopia ótica } & 58\end{array}$

4.2.6.2.2 Microscopia eletrônica de varredura $\quad 58$

$\begin{array}{ll}\text { 4.2.6.3 Atividade desnitrificante } & 58\end{array}$

4.3 REFERÊNCIAS DO CAPÍTULO 59

5 RESULTADOS E DISCUSSÃO 63

5.1 CARACTERIZAÇÃO HIDRODINÂMICA

$\begin{array}{ll}\text { 5.1.1 Curvas-resposta } & 63\end{array}$

$\begin{array}{ll}\text { 5.1.2 O efeito de cauda } & 67\end{array}$

5.1.3 Tempo de residência verdadeiro $\quad 69$

$\begin{array}{ll}\text { 5.1.4 Recuperação dos traçadores } & 69\end{array}$

5.1.5 Modelos uniparamétricos $\quad 71$

$\begin{array}{ll}\text { 5.1.6 Avaliação com dextrana azul } & 74\end{array}$

5.2 MONITORAMENTO DO DESEMPENHO DO RAALF 76

5.2.1 Análise da condição $1 \quad 77$

5.2.1.1 Dinâmica das formas nitrogenadas 77

5.2.1.2 Dinâmica de remoção da matéria orgânica carbonácea 79

5.2.1.3 Perfis espaciais das espécies de nitrogênio e da matéria orgânica carbonácea 81

5.2.1.4 Oxigênio dissolvido e potencial redox $\quad 82$

5.2.1.5 Comportamento do $\mathrm{pH}$ e alcalinidade $\quad 83$

5.2.1.6 Dinâmica das formas de enxofre $\quad 84$

5.1.7 Microrganismos: acompanhamento das morfologias $\quad 85$

$\begin{array}{ll}\text { 5.2.2 Análise da condição } 2 & 87\end{array}$

5.2.2.1 Dinâmica de remoção da matéria orgânica carbonácea 87

5.2.2.2 Dinâmica das formas nitrogenadas 93

5.2.2.3 Comportamento do $\mathrm{pH}$ e da Alcalinidade $\quad 98$

$\begin{array}{ll}\text { 5.2.2.4 Oxigênio dissolvido e potencial redox } & 100\end{array}$ 
5.2.2.6 Microrganismos: acompanhamento das morfologias

5.2.3 Analise da condição 3

5.2.3.1 Dinâmica de remoção da matéria orgânica carbonácea

5.2.3.2 Dinâmica das formas nitrogenadas

5.2.3.3 Oxigênio dissolvido e potencial redox

5.2.3.4 Comportamento do $\mathrm{pH}$ e alcalinidade

5.2.3.5 Dinâmica da desnitrificação com biogás

5.2.3.6 Microrganismos: acompanhamento das morfologias

5.3 TAXA DE DESNITRIFICAÇÃO

5.4 REMOÇÃO DO BIOGÁS

5.5. BALANÇO MATERIAL

5.6. ESTUDOS MICROBIOLÓGICOS

5.6.1 Número mais provável

5.6.2 Atividade desnitrificante

5.7 REFERÊNCIAS DO CAPÍTULO

6 CONCLUSÕES 


\section{Introdução}

"Tenho a impressão de ter sido uma criança brincando à beira-mar, divertindo-me em descobrir uma pedrinha mais lisa ou uma concha mais bonita que as outras, enquanto o imenso oceano da verdade continua misterioso diante de meus olhos."

Isaac Newton 
É consenso que a realidade social, econômica e ambiental dos países subdesenvolvidos exige o desenvolvimento incessante de alternativas sustentáveis que contemplem baixos custos de implantação, operação e manutenção no tratamento de efluentes.

Por suprir essas necessidades, a utilização de reatores anaeróbios para o tratamento de esgotos sanitários tornou-se realidade em boa parte do mundo em desenvolvimento. Atualmente, existem várias estações em operação, bem como diversos estudos acerca de sistemas que utilizam essa tecnologia. Em outras palavras, reatores anaeróbios são alternativas viáveis para o tratamento de esgotos sanitários dadas as suas vantagens econômicas associadas à sua facilidade operacional e o largo conhecimento do processo aplicado ao tratamento de efluentes, cujos estudos pioneiros remontam à década de 1960.

Embora os reatores anaeróbios possuam vantagens bem conhecidas, alguns aspectos negativos ainda são atribuídos aos mesmos, tais como a possibilidade de emanação de maus odores, a baixa capacidade do sistema em tolerar cargas tóxicas e a necessidade de uma etapa de pós-tratamento. Segue-se que a qualidade do efluente produzido por esses reatores não se enquadra nos padrões estabelecidos por legislações ambientais, uma vez que o processo anaeróbio é intrinsecamente limitado sob o ponto de vista bioquímico. Portanto, em sistemas baseados neste processo, ocorre apenas a remoção parcial de matéria orgânica carbonácea, compostos nitrogenados, compostos de fósforo, etc.

No intuito de contribuir para a solução desse problema, principalmente com relação à presença de matéria nitrogenada nos efluentes de reatores anaeróbios, alternativas de pós-tratamento têm sido estudadas, tais como: sistemas de lodos ativados, disposição controlada no solo, dentre diversos outros. Contudo, o potencial de pós-tratamento de efluentes de reatores anaeróbios em reatores de leito fixo, que possuem potencial para produzir efluentes com boa qualidade sob o ponto de vista da conversão de carbono e nitrogênio, tem sido pouco explorado.

Sabe-se que reatores de leito fixo podem garantir tempos de retenção celular elevados, condições ambientais (aeróbia e anóxica) e gradientes de concentração de oxigênio e substratos favoráveis para a ocorrência eficiente dos processos de nitrificação e desnitrificação. Ao mesmo 
tempo, o conhecimento dos mecanismos e reações que ocorrem, assim como certos cuidados operacionais para garantir a eficiência do processo, ainda são incipientemente abordados na literatura no que se refere ao pós-tratamento de efluentes anaeróbios de sistemas de tratamento de esgotos sanitários com vistas à remoção de nitrogênio em reatores de leito fixo.

A remoção biológica de nitrogênio é realizada por meio de duas etapas seqüenciais principais: a nitrificação e a desnitrificação. A etapa de desnitrificação necessita de doadores de elétrons que geralmente não estão disponíveis, em quantidade suficiente, em efluentes de reatores anaeróbios, porque, nesse estágio, a matéria orgânica que poderia ser utilizada na mesma já foi removida. Com o intuito de preencher esta lacuna, diversas pesquisas vêm abordando a utilização de doadores de elétrons alternativos para promover a redução no custo do processo de redução de nitrato.

A literatura sugere, por exemplo, a potencialidade da utilização de compostos como o metano e compostos de enxofre como doadores de interesse, visto que são produzidos durante a digestão anaeróbia, o que provocaria a integração do sistema, tanto em fase líquida quanto em fase gasosa. Essa uma nova etapa de desenvolvimento resultaria, ainda, na minimização da geração de resíduos através do seu aproveitamento. Ademais, sabe-se que a emanação de maus odores e o lançamento de gases potenciais para o efeito estufa são problemas comumente enfrentados em estações de tratamento de efluentes que utilizam reatores anaeróbios, os quais poderiam ser mitigados com base na estratégia de integração.

Entretanto, os desafios nesse sentido ainda são grandes. As incertezas sobre as possíveis interações destes processos em reatores de diferentes escalas sugerem que mais estudos neste sentido devem ser realizados visando ao aprofundamento do conhecimento para que, desta forma, sejam desenvolvidas e aprimoradas unidades de tratamento sustentáveis.

Com base em alguns resultados publicados sobre o tema, é evidente que a utilização dos compostos presentes no biogás gerado no tratamento anaeróbio $\left(\mathrm{CH}_{4}\right.$ e/ou $\left.\mathrm{H}_{2} \mathrm{~S}\right)$ na desnitrificação apresenta-se como alternativa promissora. Porém, por se tratar de tópico relativamente recente de 
investigação, devem ser aprimorados estudos que permitam um maior conhecimento dos processos que ali ocorrem e, portanto, sua adequada aplicação.

Com vista a possibilitar a melhor interação desses processos e com base nas vantagens bem conhecidas dos reatores de leito fixo aplicados ao tratamento secundário de efluentes, neste trabalho é proposta uma nova configuração de reator para o polimento de efluentes de reatores anaeróbios: o Reator Aeróbio-Anóxico de Leito Fixo (RAALF) - com fluxo descendente da fase líquida e ascendente da fase gasosa.

No que diz respeito à remoção da fração remanescente de matéria orgânica e de nitrogênio, o RAALF pode constituir-se em alternativa aos sistemas existentes, por apresentar simplicidade operacional e redução dos custos devido a utilização do biogás produzido pelo reator de montante (doador de elétrons para a desnitrificação). Além disso, possibilita a ocorrência de diferentes condições ambientais favoráveis aos diversos processos bioquímicos de interesse em uma única unidade, exigindo menor área para instalação, uma vez que é composto por duas câmaras sobrepostas. 


\section{Objetivos}

"O primeiro princípio é não enganar a si mesmo, e você é a pessoa mais fácil de enganar."

Richard Feynman 


\subsection{OBJETIVO GERAL}

Avaliar o desempenho do Reator Aeróbio-Anóxico de Leito Fixo (RAALF), com fluxo descendente, em escala de bancada, com relação à remoção de matéria orgânica e conversão da matéria nitrogenada no pós-tratamento de efluentes de reator anaeróbio do tipo UASB tratando esgoto sanitário.

\subsection{OBJETIVOS ESPECÍFICOS}

- conhecer o comportamento hidrodinâmico do reator;

- avaliar o desempenho do reator quanto à remoção de matéria orgânica carbonácea e matéria nitrogenada (nitrificação e desnitrificação);

- avaliar a utilização do biogás (metano e sulfeto de hidrogênio) no processo de desnitrificação na câmara anóxica, bem como sua utilização na câmara aeróbia;

- verificar a influência de diferentes concentrações da mistura constituinte do biogás na desnitrificação autotrófica e heterotrófica na câmara anóxica;

- avaliar o impacto da variação do tempo de detenção hidráulica nos processos de interesse;

- avaliar a diversidade da biomassa. 


\section{Revisão de Literatura}

"Circulando ao redor da terra em minha nave espacial eu notei quanto é bonito nosso planeta. Pessoas do mundo, cuidem dele e façam ele permanecer bonito, não o destruam." 


\subsection{CONSIDERAÇÕES INICIAIS}

Considerando-se a extensa abrangência deste trabalho, com relação aos tipos de reatores e processos envolvidos, associado ao fato de que atualmente existem diversos trabalhos relevantes e de alto nível sobre o processo em si, bem como a configuração de reatores, não será abordada a questão do processo anaeróbio de tratamento de efluentes nesta revisão.

Sendo assim, este capítulo foi direcionado para os processos de nitrificação e desnitrificação. Além disso, para facilitar a compreensão e a temática que é objeto de pesquisa deste trabalho, introduzem-se conceitos e definições, assim como se apresentam resultados de alguns dos estudos mais relevantes descritos na literatura.

\subsection{REMOÇÃO BIOLÓGICA DE NITROGÊNIO}

O processo convencional de remoção de nitrogênio é separado em duas etapas principais: nitrificação e desnitrificação. Consiste na remoção de nitrogênio da água residuária por meio de processos biológicos que levam à formação de gás dinitrogênio $\left(\mathrm{N}_{2}\right)$ como produto final, o qual é uma forma ambientalmente inofensiva.

\subsubsection{NITRIFICAÇÃO}

A nitrificação é geralmente realizada por microrganismos autotróficos ou mixotróficos e é a primeira etapa na remoção de compostos nitrogenados em sistemas de tratamento de esgotos.

A nitrificação convencional é obtida com fonte de carbono inorgânica, geralmente o dióxido de carbono $\left(\mathrm{CO}_{2}\right)$ e energia proveniente da oxidação de substratos inorgânicos (nitrogênio amoniacal: $\mathrm{NH}_{4}^{+}$, Amônia: $\mathrm{NH}_{3}$, além do nitrito: $\mathrm{NO}_{2}^{-}$). Assim, a amônia é oxidada em duas etapas pelos microrganismos nitrificantes, via nitrito, a nitrato. 
A oxidação da amônia a nitrito, nitritação, é geralmente atribuída aos grupos Nitrosomonas (Nitrosomonas europaea), Nitrosococcus, Nitrosospira, Nitrosolobus e Nitrosovibrio, enquanto que a oxidação do nitrito a nitrato, nitratação, é realizada pelas Nitrobacter (Nitrobacter agilis), Nitrococcus, Nitrospira e Nitrospina (Van Loosdrecht e Jetten, 1998; Hagopian e Riley, 1998).

Os dois principais grupos envolvidos no processo, Nitrosomonas e Nitrobacter, são aeróbios obrigatórios, que utilizam preferencialmente o dióxido de carbono $\left(\mathrm{CO}_{2}\right)$ como fonte de carbono. A faixa de pH ótima recomendada é entre 7-9 (Henze et al., 1997).

A reação da nitrificação pode ser descrita como (Equação 1 e Equação 2):

$$
\begin{gathered}
2 \mathrm{NH}_{3}+3 \mathrm{O}_{2} \rightarrow 2 \mathrm{NO}_{2}^{-}+3 \mathrm{H}^{+}+2 \mathrm{H}_{2} \mathrm{O} \\
\Delta \mathrm{G}^{0}=-384 \mathrm{~kJ}
\end{gathered}
$$

Equação 1

$$
\begin{gathered}
2 \mathrm{NO}_{2}{ }^{-}+\mathrm{O}_{2} \rightarrow 2 \mathrm{NO}_{3}{ }^{-} \\
\Delta \mathrm{G}^{0}=-152 \mathrm{~kJ}
\end{gathered}
$$

Equação 2

De forma geral, tem-se (Equação 3):

$$
\begin{gathered}
\mathrm{NH}_{3}+2 \mathrm{O}_{2} \rightarrow \mathrm{NO}_{3}{ }^{-}+\mathrm{H}_{2} \mathrm{O}+\mathrm{H}^{+} \\
\Delta \mathrm{G}^{0}=-268 \mathrm{~kJ}
\end{gathered}
$$

Equação 3

O efeito do processo de nitrificação sobre a alcalinidade, produção celular e consumo de oxigênio pode ser descrito por simples relações estequiométricas (Henze et al., 1997), de onde se observa que para cada mol de nitrogênio amoniacal $\left(\mathrm{NH}_{4}{ }^{+}\right)$convertido, uma quantidade significativa 
de oxigênio $\left(\mathrm{O}_{2}\right)$ é requerida, e uma quantidade importante alcalinidade $\left(\mathrm{HCO}_{3}{ }^{-}\right)$é consumida (Equação 4). Tem-se, portanto:

$$
\mathrm{NH}_{4}^{+}+1,83 \mathrm{O}_{2}+1,98 \mathrm{HCO}_{3}^{-} \rightarrow 0,98 \mathrm{NO}_{3}^{-}+1,041 \mathrm{H}_{2} \mathrm{O}+0,021 \mathrm{C}_{5} \mathrm{H}_{7} \mathrm{NO}_{2}+1,88 \mathrm{H}_{2} \mathrm{CO}_{3}
$$

Equação 4

A velocidade máxima de nitrificação ocorre para concentrações de oxigênio dissolvido (OD) acima de $2 \mathrm{mg} \mathrm{L}^{-1}$. Por outro lado, se a concentração de OD for inferior a $0,5 \mathrm{mg} \mathrm{L}^{-1}$, a velocidade de nitrificação é drasticamente reduzida e o processo pode ser interrompido (Surampalli et al., 1997).

Diversos autores indicam que a faixa ótima de temperatura para o crescimento de bactérias nitrificantes encontra-se entre $30^{\circ} \mathrm{C}$ e $35^{\circ} \mathrm{C}$. Observa-se baixo ou nulo crescimento de bactérias nitrificantes sob temperaturas de $4^{\circ} \mathrm{C}$ (Henze et al., 1997). Deve ser observado ainda que existem relatos de microrganismos imobilizados em filme fixo serem mais resistentes à mudanças de temperatura (Metcalf e Eddy, 2002).

O substrato também pode inibir as bactérias, em função de sua concentração e do meio em que elas se encontram. Geralmente, as bactérias do gênero Nitrosomonas são consideradas mais sensíveis ao excesso de substrato se comparadas com as bactérias do gênero Nitrobacter. Muitas substâncias orgânicas e inorgânicas podem inibir o processo de nitrificação (Barnes e Bliss, 1983). Algumas substâncias, como os compostos de enxofre, fenóis e cianetos podem causar inibição relativamente forte (Henze et al., 1997).

Com baixa relação de carbono/nitrogênio $(\mathrm{C} / \mathrm{N})$, as bactérias heterotróficas, limitadas pelo carbono, disponibilizam amônia em excesso para nitrificação. Para altas relações $\mathrm{C} / \mathrm{N}$, o processo de nitrificação é inibido pelo excesso de carbono orgânico e a concentração de nitrato diminui, chegando a zero (Callado, 2001). 


\subsubsection{DESNITRIFICAÇÃO}

\subsubsection{Desnitrificação convencional}

A desnitrificação compreende a última etapa para a remoção de nitrogênio por via biológica, sendo representada pela redução do nitrato $\left(\mathrm{NO}_{3}{ }^{-}\right)$a gás dinitrogênio $\left(\mathrm{N}_{2}\right)$. Esta conversão possui muitos intermediários, tais quais ácido nitroso $\left(\mathrm{HNO}_{2}\right)$, monóxido de nitrogênio $(\mathrm{NO})$ e óxido nitroso $\left(\mathrm{N}_{2} \mathrm{O}\right)$. É um processo que requer doador de elétrons, o qual pode ser material orgânico ou composto reduzido.

Os principais fatores responsáveis pelo controle do processo de desnitrificação são: temperatura, $\mathrm{pH}$, concentração de $\mathrm{OD}$, natureza da fonte de carbono, concentração de nitrato, tempo de retenção celular e a presença se substâncias tóxicas (Metcalf e Eddy, 2002).

Como exemplos de microrganismos envolvidos no processo de desnitrificação podem ser

citados: Achromobacter, Brevibacterium, Flavobacterium, Lactobacillus, Micrococcus, Proteus, Pseudomonas e Spirillum (Torres et al., 1998).

A desnitrificação é a última etapa do tratamento de água residuária com vista à remoção de nutrientes, portanto a maior parte da matéria orgânica que poderia ser utilizada no processo já foi removida. Por este motivo, torna-se necessária a adição de um doador de elétrons, seja ele interno (ex: esgoto bruto) ou externo (ex: metanol ou etanol). Alguns exemplos de reações envolvidas na desnitrificação considerando-se diferentes doadores de elétrons externos envolvidos (von Sperling, 1997; Mendonça, 2004):

$$
6 \mathrm{NO}_{3}{ }^{-}+5 \mathrm{CH}_{3} \mathrm{OH} \rightarrow 3 \mathrm{~N}_{2}+5 \mathrm{CO}_{2}+7 \mathrm{H}_{2} \mathrm{O}+6 \mathrm{OH}^{-}[\text {metanol }]
$$




$$
8 \mathrm{NO}_{3}{ }^{-}+2,5 \mathrm{CH}_{3} \mathrm{COOH} \rightarrow \mathrm{N}_{2}+2 \mathrm{CO}_{2}+8 \mathrm{HCO}_{3}{ }^{-}+6 \mathrm{H}_{2} \mathrm{O} \text { [ácido acético] }
$$

\section{Equação 6}

A desnitrificação tem sido conseguida utilizando a via convencional heterotrófica, representada pela adição de fontes de carbono externas, como etanol (Chang et al., 1992), metanol (Nyberg et al. 1992) (Equação 5), e ácido acético (Almeida et al., 1995) (Equação 6), por exemplo. Todavia, a maior desvantagem da utilização de uma fonte externa de carbono é o custo extra de produtos químicos, bem como a produção de lodo extra (Barlindhaug e Odegaard, 1996).

Uma alternativa para minimizar os custos resultantes do uso de doadores de elétrons externos é o uso de fontes oriundas de estágios anteriores à etapa de pós-tratamento. Sendo assim, os gases metano e sulfeto de hidrogênio produzidos na digestão anaeróbia tornam-se fontes prontamente disponíveis a serem utilizadas na desnitrificação.

\subsubsection{Doadores de elétrons alternativos na desnitrificação}

\subsection{Compostos de enxofre}

Algumas espécies de bactérias desnitrificantes foram isoladas para oxidar anaerobiamente compostos sulfurosos inorgânicos tais como: sulfeto, enxofre, tiosulfato e sulfito, com utilização do nitrato como aceptor de elétrons, o qual é finalmente reduzido a gás nitrogênio (Zhang e Lampe, 1999; Kim et al., 2004; Moon et al., 2004; Madigan e Martinko, 2006; Tang et al., 2009).

Espécies como o Thiobacillus thioparus conseguem apenas reduzir nitrato a nitrito, enquanto outras podem realizar a redução completa de nitrato a nitrogênio gasoso. Thiobacillus denitrificans e Thiomicrospira denitrificans são duas espécies de bactérias conhecidas como sendo obrigatoriamente quimiolitotróficas sulfurosas - com habilidade de reduzir nitrato a nitrogênio gasoso. A espécie Thiobacillus denitrificans possui a capacidade de crescer sob condições aeróbias e condições completamente anaeróbias, enquanto que a espécie Thiomicrospira denitrificans cresce bem 
anaerobiamente, entretanto só é capaz de crescer aerobiamente quando a concentração de oxigênio é extremamente baixa. Outras espécies facultativas como Thiosphaera pantotropha, Thiobacillus versutus e Paracoccus denitrificans são menos eficientes no crescimento anaeróbio, sendo que as duas últimas perdem a sua capacidade de oxidar o sulfeto sob condições anaeróbias. Sabe-se também que o gênero Beggiatoa é dependente de sulfeto para realizar a redução do nitrato a gás nitrogênio (Sweerts et al., 1990).

O processo de desnitrificação autotrófica é razoavelmente utilizado no tratamento de água residuária pobre em doadores de elétrons (Kuai e Verstraete, 1999; Hasegawa et al, 2004; Gadekar et al., 2006; Sierra-Alvarez et al., 2007), assim como para a remoção de sulfeto de hidrogênio do biogás (Kleerebezem e Mendez, 2002).

Neste processo, o nitrito pode substituir o nitrato como aceptor de elétrons para remover o sulfeto (Kleerebezem e Mendez, 2002). A bioxidação de sulfeto para enxofre ou sulfato na presença de nitrato e nitrito (condições anóxicas) pode ocorrer de acordo com as reações fornecidas a seguir (Li et al., 2009) (Equação 7-10):

$$
\begin{aligned}
& 5 \mathrm{~S}^{2-}+2 \mathrm{NO}_{3}^{-}+12 \mathrm{H}^{+} \longrightarrow 5 \mathrm{~S}+\mathrm{N}_{2}+6 \mathrm{H}_{2} \mathrm{O} \\
& \Delta \mathrm{G} 0^{\prime}=-955 \mathrm{Kj} \\
& \text { Equação } 7 \\
& 5 \mathrm{~S}^{2-}+8 \mathrm{NO}_{3}^{-}+8 \mathrm{H}^{+} \longrightarrow 5 \mathrm{SO}_{4}^{2-}+4 \mathrm{~N}_{2}+4 \mathrm{H}_{2} \mathrm{O} \\
& \Delta \mathrm{G}^{0^{\prime}}=-3693 \mathrm{Kj}
\end{aligned}
$$

Equação 8 


$$
\begin{gathered}
3 \mathrm{~S}^{2-}+2 \mathrm{NO}_{2}^{-}+8 \mathrm{H}^{+} \longrightarrow 3 \mathrm{~S}+\mathrm{N}_{2}+4 \mathrm{H}_{2} \mathrm{O} \\
\Delta \mathrm{G}^{0^{\prime}}=-917 \mathrm{Kj}
\end{gathered}
$$

\section{Equação 9}

$$
\begin{gathered}
3 \mathrm{~S}^{2-}+8 \mathrm{NO}_{2}^{-}+8 \mathrm{H}^{+} \longrightarrow 3 \mathrm{SO}_{4}^{2-}+4 \mathrm{~N}_{2}+4 \mathrm{H}_{2} \mathrm{O} \\
\Delta \mathrm{G}^{0^{\prime}}=-2944 \mathrm{Kj}
\end{gathered}
$$

Equação 10

Importante salientar que a oxidação do enxofre, na presença de oxigênio, relaciona-se preferencialmente com a redução do oxigênio, o que indica que a desnitrificação usando sulfeto de hidrogênio $\left(\mathrm{H}_{2} \mathrm{~S}\right)$ como doador de elétrons ocorre só para níveis de oxigênio inferiores a $1 \mathrm{mg} \mathrm{L}^{-}$ ${ }^{1}$ (Sublette et al., 1998).

Beristain-Cardoso et al. (2006) investigaram a fisiologia e cinética da desnitrificação quimiolitotróficas utilizando sulfeto de hidrogênio, enxofre elementar ou tiossulfato como doadores de elétrons. A atividade metabólica do processo foi consideravelmente maior com o uso de tiossulfato em comparação com os outros compostos. Foi observada a completa oxidação de sulfeto a sulfato quando as concentrações de nitrato foram iguais ou superiores em relação ao requerido estequiometricamente. Quando as concentrações de nitrato foram limitantes, ocorreu somente oxidação parcial de sulfeto a enxofre elementar. O aumento da concentração de sulfeto de 2,5 a $10 \mathrm{mM}$ inibiu os processos de conversão do nitrato e geração de sulfato. Os autores concluiram que a velocidade de desnitrificação e sulfo-oxidação depende fortemente dos compostos inorgânicos de enxofre utilizados como doadores de elétrons.

Moraes (2009) constatou a viabilidade técnica da aplicação da desnitrificação autotrófica usando sulfeto como doador de elétrons no tratamento de efluentes de reatores anaeróbios nitrificados e parcialmente nitrificados, empregando biomassa imobilizada. Variou-se a concentração de sulfeto, obtendo-se diferentes relações N/S. Constatou-se desnitrificação completa de ambos os receptores 
estudados; entretanto, isto só ocorreu com estabilidade para relações N/S inferiores a relação estequiométrica baseada nas reações químicas correspondentes, isto e, quando foi aplicado sulfeto em excesso. Os resultados mostraram que a oxidação total ou parcial dos compostos de enxofre no processo depende da relação N/S, e a velocidade de consumo de nitrato foi maior que a de nitrito. Posteriormente, realizaram-se novos ensaios semelhantes ao anterior, porem, a alimentação consistiu na mistura do efluente sintético nitrificado a efluente de reator anaeróbio tratando água residuária de abatedouro de aves, e o único receptor de elétrons aplicado foi nitrato. Neste caso, foi constatada desnitrificação completa na relação N/S correspondente a estequiometria relativa a sulfeto e nitrato. A cinética de remoção de nitrogênio seguiu modelo de decaimento exponencial de primeira ordem; entretanto, houve limitação a transferência de massa intraparticular e na fase liquida, fato que caracterizou os modelos ajustados como sendo de primeira ordem.

Embora os resultados obtidos em diferentes pesquisas apresentem o uso do sulfeto e do enxofre elementar como opções promissoras são necessários mais estudos para o melhor entendimento dos mecanismos que envolvem o processo e o seu desenvolvimento em outras configurações de reatores.

\subsection{Metano}

O metano surge como uma alternativa barata e prontamente disponível para a desnitrificação uma vez que é produzido durante a digestão anaeróbia na etapa de metanogênese. Todavia, poucos estudos sobre a utilização do metano no processo de desnitrificação têm sido realizados sendo que um dos motivos é de alguns dos primeiros estudos sobre este tema (Harremoes e Christensen, 1971; Davies, 1973; Rajapakse e Scutt, 1999) apresentaram baixas taxas de desnitrificação.

Os microrganismos metilotróficos (sendo as metanotróficas um subgrupo) compõem um grupo diverso capaz de utilizar compostos reduzidos de um carbono, tais com metanol e metano, para seu crescimento sob condições aeróbias (Davies, 1973; Anthony, 1982). 
Todas as bactérias metanotróficas isoladas são aeróbias estritas que podem utilizar usar amônia, nitrato e, em alguns casos, nitrito como fonte de nitrogênio, e muitas delas podem fixar nitrogênio. Existem bactérias metanotróficas capazes de reduzir de uma forma dissimilativa nitrato a nitrito e oxidar amônia via oxido nitroso a nitrito (Eisentraeger et al., 2001).

Ressalta-se que pesquisas realizadas até o momento apontam para a não existência de resultados definitivos no que tange ao enriquecimento de culturas com metano, sob condições anóxicas ou anaeróbias.

No entendimento de Eisentraeger et al. (2001), a comprovação de que o metano é oxidado pela enzima mono-oxigenase (Mason, 1977) talvez seja o único indicativo favorável nas pesquisas sobre a metabolização do metano na ausência de oxigênio. Todavia, alguns estudos realizados suportam a hipótese de que o metano possa ser, de fato, utilizado como fonte de carbono sob tais condições.

Cálculos termodinâmicos mostram que a maioria das associações ecológicas relativas ao grupos de microrganismos que podem utilizar o metano de forma anóxica já foram descobertas, entretanto estes microrganismos ainda não foram encontrados na natureza (Sollo et al., 1976; Mason , 1977; Valentine, 2002; Strous e Jetten, 2004; Knowles, 2005; Shima e Thauer, 2005; Raghoebarsing et al., 2006). As equações sugeridas para o processo são a que seguem (Equação 11 e Equação 12):

$$
\begin{gathered}
5 \mathrm{CH}_{4}+8 \mathrm{NO}_{3}^{-}+8 \mathrm{H}^{+} \longrightarrow 5 \mathrm{CO}_{2}+4 \mathrm{~N}_{2}+14 \mathrm{H}_{2} \mathrm{O} \\
\Delta \mathrm{G}^{0^{\prime}}=-765 \mathrm{~kJ} \mathrm{~mol}^{-1} \mathrm{CH}_{4}
\end{gathered}
$$

Equação 11

$$
\begin{gathered}
3 \mathrm{CH}_{4}+8 \mathrm{NO}_{2}^{-}+8 \mathrm{H}^{+} \longrightarrow 3 \mathrm{CO}_{2}+4 \mathrm{~N}_{2}+10 \mathrm{H}_{2} \mathrm{O} \\
\Delta \mathrm{G}^{0^{\prime}}=-928 \mathrm{~kJ} \mathrm{~mol}^{-1} \mathrm{CH}_{4}
\end{gathered}
$$

Equação 12 
Como a oxidação anaeróbia do metano associada à desnitrificação é possível na teoria, tanto sob o ponto de vista termodinâmico quando bioquímico (por meio da metanogênese reversa - Kruger et al., 2003 e Hallam et al., 2004), tais microrganismos podem de fato existir e consequentemente nossa compreensão do ciclo biogeoquímico do metano pode estar incompleta. A falta de evidência experimental da ocorrência da oxidação anaeróbia do metano associada à desnitrificação talvez não seja tão surpreendente, porque este processo seria esperado que ocorresse na natureza próximo da interface óxica/anóxica nos sedimentos.

Outra possibilidade da ocorrência da desnitrificação por meio da utilização do metano foi demonstrada por Werner e Kaiser (1991). Neste caso, dois grupos de bactérias estão envolvidos: metanotróficas oxidadoras de metano e metilotróficas desnitrificantes utilizadoras de metanol, conforme as etapas a seguir (Equação 13), sendo que a oxidação do metano a metanol é catalisada pela enzima mono-xigenase, enquanto que outras oxidações são catalisadas pela dehidrogenase:

$$
\begin{aligned}
\mathrm{CH}_{4}+\mathrm{O}_{2}+2 \mathrm{H}^{+} \longrightarrow \mathrm{H}_{2} \mathrm{O}+\mathrm{CH}_{3} \mathrm{OH} \stackrel{1,5 \mathrm{O}_{2}}{\longrightarrow} & \mathrm{CO}_{2}+2 \mathrm{H}_{2} \mathrm{O} \\
& \downarrow 6 / 5 \mathrm{NO}_{3} \\
& 3 / 5 \mathrm{~N}_{2}+7 / 5 \mathrm{H}_{2} \mathrm{O}+6 / 5 \mathrm{OH}^{-}+\mathrm{CO}_{2}
\end{aligned}
$$

Equação 13

Nota-se que o oxigênio é necessário para que a produção do metanol ocorra. Portanto, condições estritamente anóxicas são contraprodutivas neste caso. Por outro lado, se o oxigênio estiver em excesso ocorrerá a oxidação completa do metano a dióxido de carbono e água (Teixeira et al., 2009), conforme descrito na Equação 14:

$$
\mathrm{CH}_{4}+2 \mathrm{O}_{2} \longrightarrow \mathrm{CO}_{2}+2 \mathrm{H}_{2} \mathrm{O}
$$

Equação 14 
Thalasso et al. (1997) avaliaram a desnitrificação de água residuária com o metano como única fonte de carbono, sob condições anóxica e aeróbia. Sob condições anóxicas, a desnitrificação não foi significativa. Porém, na presença de oxigênio a desnitrificação foi bem sucedida e dependeu da pressão parcial do oxigênio, todavia não ficou bem esclarecida a influência do oxigênio para o sucesso do processo, bem como os mecanismos químicos e ecológicos envolvidos.

Rajapakse e Scutt (1999) estudaram a desnitrificação em um reator com filme fixo, testando diferentes tipos de material suporte, com cultura desnitrificante composta de bactérias metilotróficas, e gás natural ( $95 \%$ metano) como fonte de carbono. Foi confirmada a viabilidade do uso de gás natural para desnitrificação, quando são mantidas dentro do reator condições aeróbias e anaeróbias. Segundo os autores, a biomassa desnitrificante avaliada adaptou-se rapidamente ao uso do metano.

Costa et al. (2000) estudaram a desnitrificação em um reator de leito fixo e utilizando gás metano como doador de elétrons, sob duas condições: presença e limitação de oxigênio, para identificar os possíveis compostos envolvidos no processo. Os autores propuseram ser o acetato o composto produzido pelas metanotróficas durante crescimento, sob concentração limitada de oxigênio, e é este composto o doador de elétrons utilizado pelas desnitrificantes.

Eisentraeger et al. (2001) avaliaram o uso de metano para a desnitrificação in situ de aquíferos. Como a oxidação do metano não ocorreu na ausência de oxigênio, os autores sugerem que a desnitrificação com metano só ocorrerá sob condições heterótrofas, em sistemas aeróbio-anaeróbio, onde as bactérias metanotróficas aeróbias produzem metabólitos, que são usados em condições anóxicas como doadores de hidrogênio pelas bactérias não metanotróficas, as quais foram capazes de realizar a desnitrificação utilizando metanol, acetato ou proteínas como fontes de carbono.

Gavazza (2003) avaliou comparativamente o desempenho de reatores desnitrificantes em batelada, tendo etanol, metanol e gás metano como doadores de elétrons. No estudo, apesar de o metano não ter sido tão eficiente como doador de elétrons quanto os demais, a desnitrificação foi alcançada com sucesso, tendo sido detectado que a resistência à transferência de massa exerce grande 
influência sobre o processo, pois, para o metano estar disponível à biomassa, deve estar dissolvido na massa líquida.

Cuba (2008) estudou a remoção de nitrogênio em um reator operado em bateladas seqüenciais submetido a períodos aeróbios e anóxicos. Metano foi adicionado como doador de elétrons na etapa desnitrificante nos períodos anóxicos. Foram testadas diferentes condições operacionais e nutricionais com o objetivo de se alcançar a melhor eficiência de remoção de nitrogênio. A desnitrificação foi principalmente associada com o uso de subprodutos metabólicos no lugar do metano. De forma a diminuir o consumo de material endógeno, a biomassa foi imobilizada em material suporte (espuma de poliuretano) e os períodos aeróbios e anóxicos foram diminuídos para 3 horas cada (etapa 3) e posteriormente, $0,5 \mathrm{~h}$ e 1,5 h (etapa 4). Nesta última etapa, as maiores eficiências de remoção de nitrogênio, $(\sim 35 \%)$ foram verificadas somente nos primeiros dias de operação. O processo de desnitrificação utilizando metano como doador de elétrons também foi estudado sob condições anóxicas tendo nitrato e, posteriormente, nitrito como fontes de nitrogênio oxidadas. Nesses experimentos, as eficiências de remoção de nitrogênio foram de $75 \%$ e $90 \%$.

\subsubsection{OUTROS PROCESSOS UTILIZADOS NA REMOÇÃO BIOLÓGICA DE NITROGÊNIO}

Cabe ainda ressaltar que, recentemente, uma ampla gama de novos processos biológicos tem sido investigada em laboratório, tais como: oxidação anaeróbia da amônia (Annamox) (Strous et al., 1999; Kuenen e Jetten, 2001; Kuypers et al., 2003), desnitrificação por bactérias nitrificantes autotróficas (Bock et al., 1995; Bock et al., 1998), nitrificação e desnitrificação simultâneas (Tchobanoglous et al., 2003; Nielson t al., 2004; Hwang et al., 2005), desnitrificação aeróbia (Robertson e Kuenen, 1984; Lloyd, 1993) e nitrificação heterotrófica (Focht e Chang, 1975).

Estes processos podem explicar perdas de nitrogênio ainda não esclarecidas nos sistemas de tratamento de esgoto. 


\subsection{REATORES DE LEITO-FIXO APLICADOS AO PÓS-TRATAMENTO DE EFLUENTES DE REATORES ANAERÓBIOS COM UTILIZAÇÃO DE BIOGÁS}

Teoricamente, qualquer unidade anaeróbia utilizada para remoção biológica de matéria orgânica pode ser seguida de uma alternativa para nitrificação combinada com qualquer unidade para desnitrificação. Existem diversas configurações possíveis para sistemas de tratamento de águas residuárias destinados à remoção de matéria orgânica e de macro-nutrientes. Atualmente, existem pesquisas relatadas na literatura que têm como proposta reatores combinados anaeróbios-aeróbios ou anaeróbios-aeróbio-anaeróbios os quais têm obtido resultados interessantes. Sistemas compostos por reatores anaeróbios como, por exemplo, UASB, Anaerobic Sequencing Batch Reactor (ASBR) ou Reator anaeróbio horizontal de leito fixo (RAHLF) seguidos de reatores aeróbios como Filtro Aerado Submerso, Filtro Aerado, Rotating Biological Contactors (RBC), Lodos Ativados e Sequencing Batch Reactor (SBR) têm apresentado bons resultados. Há, ainda, pesquisas que visam adaptar reatores em escala real para alternarem fases aeróbias e anaeróbias em um único reator, com objetivo primário de obter remoção de nitrogênio e fósforo e economizar energia.

Garbossa (2006) avaliou duas configurações diferentes de reatores com biomassa imobilizada em matrizes cúbicas de poliuretano: a) Reator Misto Radial de Leito Fixo (RMRLF), utilizado para o tratamento de esgoto sanitário, e b) Reator Aeróbio-Anaeróbio Horizontal de Leito Fixo (RAAHLF), utilizado no pós-tratamento de efluente de reator UASB tratando esgoto sanitário. Ambos os reatores foram operados à temperatura ambiente, na faixa mesofílica. Os valores de DQO no efluente do reator mantiveram média inferior a $50 \mathrm{mg} \mathrm{L}^{-1}$. A remoção de $\mathrm{N}-\mathrm{NO}_{3}{ }^{-}$aumentou em $75 \%$ após o início do fornecimento do $\mathrm{H}_{2} \mathrm{~S}$ por meio da injeção de biogás no RMRLF. Os valores de DQO no efluente, em média, foram inferiores a $70 \mathrm{mg} \mathrm{L}^{-1}$ e a remoção de nitrato foi incrementada em quase $90 \%$ após o fornecimento do $\mathrm{H}_{2} \mathrm{~S}$ pela injeção de biogás na câmara anóxica do RAAHLF. Demonstrou-se, portanto, o potencial destes reatores como alternativa para o tratamento e pós-tratamento de esgoto sanitário tendo em vista os resultados promissores de remoção de matéria orgânica e nitrogênio. 
Victoria (2006) avaliou a utilização do biogás produzido em reator UASB como doador de elétrons para desnitrificação em uma configuração alternativa de filtro biológico percolador, intitulada de Filtro Biológico Aeróbio-Anóxico (FBAA). Embora a nova configuração de FB tenha permitido a ocorrência dos processos de nitrificação e desnitrificação, a autora ressaltou a necessidade de mudanças no projeto da interface entre os compartimentos aeróbio e anóxico para evitar o acúmulo de biomassa no local. A configuração de leito fixo ofereceu condições favoráveis para a aderência e colonização de biomassa. A nitrificação ocorreu de forma eficiente, obtendo-se entre 60 e $74 \%$ de conversão de nitrogênio amoniacal, sendo que o efluente final apresentou, em média, concentração abaixo de $10 \mathrm{mg} \cdot \mathrm{L}^{-1}$. A desnitrificação ocorreu de forma bastante satisfatória mesmo na presença de oxigênio dissolvido, e foram obtidas concentrações de nitrato inferiores a $10 \mathrm{mg} \mathrm{L}^{-1}$. A autora ressaltou a possibilidade de se obter maiores eficiências de remoção, todavia as condições anóxicas no compartimento desnitrificante deveriam ser mantidas. A autora demonstrou que a utilização de biogás $\left(\mathrm{CH}_{4}\right.$ e $\left.\mathrm{H}_{2} \mathrm{~S}\right)$ como doador de elétrons para desnitrificação em filtro biológico de dois compartimentos pode ser viável e eficiente. Entretanto, a despeito de o $\mathrm{CH}_{4}$ ter sido o principal constituinte do biogás, não foi possível confirmar sua efetiva utilização no processo de desnitrificação. Por outro lado foi possível constatar a oxidação do $\mathrm{H}_{2} \mathrm{~S}$ a sulfato, o que demonstrou a capacidade adicional do reator no tratamento de biogás.

Souza (2011) avaliou a desnitrificação autotrófica usando sulfeto como doador de elétrons para remoção de nitrogênio de efluentes de reatores anaeróbios tratando esgoto sanitário em escala de bancada tratando esgoto sintético e em escala piloto tratando esgoto real. A ocorrência da desnitrificação autotrófica foi detectada no sistema de reatores em bancada, e houve indícios de sua presença no sistema em escala piloto. Tanto no sistema de bancada quando no piloto foi possível a remoção global de nitrogênio de, em média, $40 \%$ apenas com doadores de elétrons endógenos, através da nitrificação de 40 a $60 \%$ da vazão total e posterior mistura com a fração não-nitrificada. A perda de sulfeto nos reservatórios intermediários do sistema de reatores da segunda etapa foi considerada um obstáculo ao processo, que foi solucionado com a nova configuração proposta na terceira etapa e 
aplicada em escala piloto. Embora a gama variada de processos possíveis em seu interior não tenha sido completamente elucidada, o sistema piloto promoveu tratamento secundário e terciário de esgoto sanitário, com remoção de nitrogênio e atendimento aos padrões de emissão deste parâmetro. Os resultados obtidos na pesquisa mostraram que o processo é versátil e pode coexistir com outros processos, apresentando viabilidade e potencial no tratamento de efluentes de reatores anaeróbios utilizados no tratamento de esgotos sanitários.

\subsection{COMPORTAMENTO HIDRODINÂMICO}

Na presente pesquisa é apresentada uma nova configuração de reator para o pós-tratamento de efluentes de reatores anaeróbios. O reator é composto de duas câmaras sobrepostas e interligadas, sendo fluxo da fase gasosa (ar e biogás) do tipo ascendente e o da fase líquida (esgoto) descendente. Tais peculiaridades dificultam a determinação das condições hidrodinâmicas do reator, se tivermos em mente os estudos relatados na literatura.

O principal objetivo do estudo hidrodinâmico é a determinação das curvas de distribuição do tempo de residência do líquido, a partir do qual pode se obter o grau de mistura, dentre outras informações importantes, tais como: zonas mortas, caminhos preferenciais e recirculação interna. As condições de mistura em reatores quaisquer em operação encontram-se entre os modelos de fluxo em pistão e de mistura completa ideal (Levenspiel, 2000).

De acordo com Von Sperling (2006) em um fluxo do tipo pistão ideal o escoamento do fluido ocorre de forma ordenada através do reator, ou seja, não há mistura ou difusão ao longo do caminho de escoamento. Por outro lado, se a concentração de qualquer parâmetro for igual em qualquer ponto do reator tem-se a mistura completa ideal.

A maneira mais comum de realizar o estudo hidrodinâmico é através de testes com traçadores, que podem ser compostos químicos radioativos, fluorescentes, ionizáveis e corantes, dentre outros. 
Esses traçadores são utilizados em ensaios de estímulo-resposta, os quais fornecem curvas cuja análise nos permite verificar de qual tipo de modelo de escoamento o sistema estudado se aproxima.

Existem vários fatores que influenciam o comportamento hidrodinâmico do líquido em reatores de leito fixo, sendo os principais a velocidade de escoamento, a velocidade das bolhas de gás, e as características do leito do reator (Santos, 2004).

\subsection{CONSIDERAÇÕES FINAIS}

Até o momento, os avanços obtidos na área de remoção biológica de nitrogênio de águas residuárias têm sido importantes, entretanto ainda existem aspectos que necessitam de aprofundamento. Conforme observado com base na revisão da literatura, são muitas as variáveis determinantes a serem consideradas na obtenção da remoção biológica de nitrogênio.

Através dos trabalhos da revisão é possível observar que sistemas com biofilme têm, entre outras vantagens, a habilidade de sustentar uma grande variedade de populações microbianas, em diferentes locais do biofilme, o que permite a ocorrência simultânea de diferentes processos biológicos. Esta habilidade torna esse tipo de sistema atrativo, quando se querem propor alternativas de tratamento compactas e efetivas.

Portanto, reatores de leito fixo apresentam-se como alternativas viáveis, embora certas condições ecológicas e hidráulicas devam ser mantidas para evitar inibição dos processos bioquímicos.

Pela bibliografia consultada é evidente que a utilização do metano e ou de sulfeto de hidrogênio presente no biogás gerado no tratamento anaeróbio, como fonte externa de carbono para a desnitrificação, apresenta-se como uma alternativa promissora, porém, por se tratar de técnica recente, devem ser aprimorados estudos que permitam um maior conhecimento dos processos que ali ocorrem e, portanto, sua adequada aplicação. 


\subsection{REFERÊNCIAS DO CAPÍTULO}

Almeida J. S., Julio S. M., Reis M. A. M., and Carrondo M. J. T. (1995) Nitrite inhibition of denitrification by confirms the results found in the study of the specific Pseudomonasfluorescens. Biotechnology and Bioengineering 46, 194-201.

Anthony, C. (1982) The Biochemistry of Methylotrophs. Academic press, London, 350p.

Barlindhaug J.; Odegaard H. (1996) Thermal hydrolysate as a carbon source for denitrification. Water Science and Technology 33, 99-108

Barnes, D.; Bliss, P. J. (1983) Biological control nitrogen in wastewater treatment. E. \& F. N. Spon, Cambridge, Great Britain. 192p.

Beristain-Cardoso, R.; Sierra-Avarez, R.; Rowlette, P.; Flore, E.R.; Gomez, J.; Field, J.A. (2006) Sulfide oxiodation under chemiolitrothopic denitrifying conditions. Biotechnology and Bioengineering. 95(6), 1148-1157.

Bock, E.; Schmidt, I.; Stuven, R.; Zart, D. (1995) Nitrogen loss caused by denitrifying Nitrosomonas cells using ammonium or hydrogen as electron donors and nitrite as electron acceptor. Archives of Microbiology. 163,16-20.

Bock, E.; Wilderer, P.A.; Freitag, A. (1998) Growth of Nitrobacter in the absence of dissolved oxygen. Water Research. 22, 245-250.

Callado, N.H. (2001) Reatores seqüenciais em batelada em sistema anaeróbio/aeróbio tratando esgoto sanitário sintético e com a remoção de nutrientes. Tese (Doutorado) - Escola de Engenharia de São Carlos, Universidade de São Paulo.

Chang J.; Erb. M.; Manem J. (1992) Membrane must be as high as possible. An economic study must bioreactor for denitrification of potable water. Membrane Processes 6 (21), 103-108.

Costa, C.; Dijkema, C.; Friedrich, M.; García-Encina, P.; Fernández-Polanco, F.; Stams, A.J. (2000) Denitrification with methane as electron donor in oxygen-limited bioreactors. Applied microbiology and biotechnology. 53, 754-762.

Cuba, R.M.F. (2008) Utilização do metano como doador de elétrons para remoção de nitrogênio via nitrificação e desnitrificação em reator operado em bateladas seqüenciais. Tese (Doutorado) - Escola de Engenharia de São Carlos, Universidade de São Paulo, São Carlos

Davies, T. R. (1973) Isolation of bacteria capable of utilizing methane as a hydrogen donor in the process of denitrification. Water Research. 7, 575-579.

Eisentraeger, A.; Klag, P.; Vansbotter, B.; Heymann, E.; Dott, W. (2001) Denitrification of groundwater with methane as sole hydrogen donor. Water Research. 35(9), 2261-2267.

Focht, D.D.; Chang A.C. (1975) Nitrification and denitrification processes related to waste water treatment. Advances Applied Microbiology 19, 153-186. 
Gadekar, S.; Nemati, M.; Hill, G.A. (2006) Batch and continuous biooxidation of sulphide by Thiomicrospira sp. CVO: reaction kinetics and stoichiometry. Water Research. 40, 2436-2446.

Garbossa, L.H.P. (2006) Avaliação de Sistemas Anaeróbio-Aeróbio com Biomassa Imobilizada para Remoção de Matéria Carbonácea e Nitrogênio de Esgoto Sanitário e uso do Biogás na Desnitrificação. Tese (Doutorado), Escola de Engenharia de São Carlos, Universidade de São Paulo, São Carlos.

Gavazza, S. (2003). Utilização de metanol, etanol e metano como doadores de eletrons para a desnitrificação. Tese (Doutorado) - Escola de Engenharia de São Carlos, Universidade de São Paulo, São Carlos.

Hagopian, D.S.; Riley, G.J. (1998) A closer look at bacteriology of nitrification. Aquacultural Engineering. 18, 223-244.

Hallam, S.J.; Putnam, N.; Preston, C.M.; Detter, J.C.; Rokhsar, D.; Richardson, P.M.; DeLong, E.F. (2004) Reverse methanogenesis: testing the hypothesis with environmental genomics. Science. $305,1457-1462$.

Harremoes, P.; Christensen, M. (1971) Denitrification med methane. Vand. 1,7-11.

Hasegawa, K.; Shimizu, K.; Hanaki, K. (2004) Nitrate removal with low $\mathrm{N}_{2} \mathrm{O}$ emission by application of sulfur denitrification in actual agricultural field. Water Science and Technology. 50, $145-151$.

Henze, M.; Harremoes, P.; Jansen, J.L.C.; Arvin, E. (1997) Wastewater treatment: biological and chemical processes. $2^{\mathrm{a}}$ Edição, Berlin Heidelberg: Springer Verlag. 383p.

Hwang, Y.; Kim, C.; Choo, I. (2005) Simultaneous Nitrification/Denitrification in a Single Reactor using Ciliated Columns Packed with Granular Sulfur. Water Quality Research Journal of Canada. 40, 91-96.

Kim, H.R.; Lee, I.S.; Bae, J.H. (2004) Performance of a sulphur-utilizing fluidized bed reactor for post-denitrification. Process Biochemistry. 39, 1591-1597

Kleerebezem, R.; Mendez, R. (2002) Autotrophic denitrification for combined hydrogen sulfide removal from biogas and post-denitrification. Water Science and Technology. 45, 349-356.

Knowles, R. (2005) Denitrifiers associated with methanotrophs and their potential impact on the nitrogen cycle. Ecological Engineering. 24, 441-446.

Kruger, M.; Meyerdierks, A.; Glockner, F.O.; Amann, R.; Widdel, F.; Kube, M.; Reinhardt, R.; Kahnt, J.; Bocher, R.; Thauer, R.K.; Shima, S. (2003) A conspicuous nickel protein in microbial mats that oxidize methane anaerobically. Nature. 426, 878-881.

Kuai, L.P.; Verstraete, W. (1999) Autotrophic denitrification with elemental sulphur in smallscale wastewater treatment facilities. Environmental Technology. 20(2), 201-209. 
Kuenen, J. G.; Jetten, M.S.M. (2001) Extraordinary anaerobic ammonium-oxidizing bacteria. American Society for Microbiology News. 67, 456-463.

Kuypers, M.M.M.; Sliekers, A.O.; Lavik, G.; Schmidt, M.; Jorgensen, B.B.; Kuenen, J.G.; Damste, J.S.S.; Strous, M.; Jetten, M.S.M. (2003) Anaerobic ammonium oxidation by anammox bacteria in the Black Sea. Nature. 422, 608-611.

Levenspiel, O. (2000) Engenharia das reações químicas. $3^{\mathrm{a}}$ Edição. Editora Edgard Blucher Ltda.

Li, W.; Zhao, Q.; Liu, H. (2009) Sulfide removal by simultaneous autotrophic and heterotrophic desulfurization-denitrification process. Journal of Hazardous Materials. 162, 848-853

Lloyd, D. (1993) Aerobic denitrification in soils and sediments: from fallacies to facts. Trends in Ecology \& Evolution. 8 (10), 352-356.

Madigan, M.T.; Martinko, J.M. (2006) Brock Biology of Microorganisms. $11^{\text {a }}$ Edição. Ed., Prentice Hall, Upper Saddle River, NJ.

Mahmood, Q.; Zheng, P.; Cai, J.; Wu, D.; Hu, B.; Li, J. (2007) Anoxic sulfide biooxidation using nitrite as electron acceptor. Journal of Hazardous Materials. 147, 249-256.

Mason, I. (1977) Methane as a carbon source in biological denitrification. Journal of Water Pollution Control Federation. 49, 855-857.

Mason, I. (1977) Methane as a carbon source in biological denitrification. Journal of water pollution control federation. $49,855-857$.

Mendonça, N.M. (2004) Tratamento de esgoto sanitário empregando reator anaeróbio-aeróbio de leito expandido em escala plena com zonas anaeróbia e aeróbia sobrepostas: concepção, construção e operação. Tese (Doutorado), Escola de Engenharia de São Carlos, Universidade de São Paulo, São Carlos.

Metcalf and Eddy (2002) Wastewater Engineering: Treatment, Disposal and Reuse. 4 a Edição, New York, McGraw-Hill, Inc. 1334p.

Moon, H.S.; Ahn, K.H.; Lee, S. (2004) Use of autotrophic sulfur-oxidizers to remove nitrate frombank filtrate in a permeable reactive barrier system. Environmental Pollution. 129, 499-507.

Moraes, B.S. (2009) Utilização de sulfeto como doador de elétrons para a desnitrificação autotrófica aplicada ao tratamento de esgoto sanitário. Dissertação (Mestrado) - Escola de Engenharia de Sao Carlos, Universidade de Sao Paulo, São Carlos.

Nielson, P.H.; Thompson, T.R.; Nielson, J.L. (2004) Bacterial Composition of Activated Sludge - Importance for Floc and Sludge Properties. Water Science and Technology. 49, 51-58.

Nyberg, U., Aspegren, H., Andersson, B., Jansen, J., Cour, L., and Villadsen, I.S. (1992) Fullscale application of nitrogen removal with methanol as carbon source. Water Science and Technology 26, 1077. 
Raghoebarsing, A.A.; Pol1, A. van de Pas-Schoonen, K.T.; Smolders, A.J.P.; Ettwig, K.F.; Rijpstra, W.I.C.; Schouten, S.; Damste, J.S.S.; den Camp, H.J.M.O.; Jetten, M.S.M.; Strous, M. (2006) A microbial consortium couples anaerobic methane oxidation to denitrification. Nature 440, 918-921.

Rajapakse, J. P.; Scutt, J. E. (1999) Denitrification with natural gas and various new growth media. Water Research 33(18), 3723-3734.

Robertson, L.A.; Kuenen, J. G. (1984) Aerobic denitrification: a controversy revived. Archives of Microbiology. 139(4), 351-354.

Santos, P.I.O. (2004) Remoção de DQO e nitrogênio, e estudo do consórcio microbiano em sistema com três reatores, em série, alimentado co m esgoto sanitário. Tese (Doutorado) - Escola de Engenharia de São Carlos, Universidade de São Paulo, São Carlos.

Shima, S.; Thauer, R. K. (2005) Methyl-coenzyme M reductase and the anaerobic oxidation of methane in methanotrophic Archaea. Current Opinion in Microbiology 8, 643-648.

Sierra-Alvarez, R.; Beristain-Cardoso, R.; Salazar, M.; Gomez, J.; Razo-Flores, E.; Field, J.A. (2007) Chemolithotrophic denitrification with elemental sulfur for groundwater treatment. Water Research 41, 1253-1262.

Sollo Jr., F.W.; Mueller, H.F.; Larson, T. E. (1976) Denitrification of wastewater effluents with methane. Journal of Water Pollution Control Federation 48(7), 1840-1842.

Souza, T. S. O. (2011) Desnitrificação autotrófica usando sulfeto como doador de elétrons para remoção de nitrogênio de efluentes de reatores anaeróbios utilizados no tratamento de esgotos sanitários. Tese (Doutorado) - Escola de Engenharia de São Carlos, Universidade de São Paulo, São Carlos.

Strous, M.; Fuerst, J.A.; Kramer, E.H.M.; Logemann, S.; Muyzer, G.; van de Pas-Schoonen, K.T.; Webb, R.; Kuenen, J.G.; Jetten, Mike S.M. (1999) Missing litotroph identified as new planctomycete. Nature 400, 446-449.

Strous, M.; Jetten, M.S.M. (2004) Anaerobic oxidation of methane and ammonium. Annual Reviews in Microbiology 58, 99-117.

Sublette, K.L.; Kolhatkar, R.; Raterman, K. (1998) Technological aspects of the microbial treatment of sulfide-rich wastewater: A case study. Biodegradation 9, 259-271.

Surampalli, R.Y.; Tyagi, R.D.; Scheible, O.K.; Heidman, J.A. (1997) Nitrification, denitrification and phosporus removal in sequential batch reactors. Bioresource Technology 61, 151157.

Sweerts, J.P.R.A.; de Beer, D.; Nielsen, L.P.; Verdouw, H.; van den Heuvel, J.C.; Cohen, Y.; Cappenberg, T.E. (1990) Denitrification by sulphur oxidizing Beggiatoa spp. mats on freshwater sediments. Nature 344, 762-763. 
Tang, K.; Baskaran, V.; Nemati, M. (2009) Bacteria of the sulphur cycle: An overview of microbiology, biokinetics and their role in petroleum and mining industries. Biochemical Engineering Journal 44, 73-94

Tchobanoglous, G.; Burton, F.; Stensel, H. (2003) Wastewater Engineering. $4^{\mathrm{a}}$ Edição. Mc Graw Hill, Inc. New York.

Teixeira, C.E.; Torves, J.C.; Finotti, A.R.; Fedrizzi, F.; Marinho, F.A.M.; Teixeira, P.F. (2009) Estudos sobre a oxidação aeróbia do metano na cobertura de três aterros sanitários no Brasil. Engenharia Sanitária e Ambiental 14(1), 99-108.

Thalasso, F.; Vallecillo, A.; García-Encina, P.; Fdz-Polanco, F. (1997). The use of methane as a sole carbon source for wastewater denitrification. Water Research 31(1), 55-60.

Torres, S.; Aspé, E.; Martí, M.C.; Roeckel, M. (1998) Analysis of kinetics of denitrification in the presence of different electron donors and its application to fisheries effluents. In: V Taller y Seminário Latinoamericano Tratatamento Anaeróbio de Águas Residuales. Chile. p1-16.

Valentine, D. L. (2002) Biogeochemistry and microbial ecology of methane oxidation in anoxic environments: a review. Antonie van Leeuwenhoek International Journal of General and Molecular Microbiology 81, 271-282.

Van Loosdrecht, M.C.M.; Jetten, M.S.M. (1998) Microbiological conversions in nitrogen removal. Water science and technology 38(1), 1-7.

Victoria, J.A.R. (2006) Filtro Biológico Aerobio-Anóxico para remoção de nitrogênio de reatores UASB. Tese (Doutorado)-Escola de Engenharia de São Carlos, Universidade de São Paulo, São Carlos.

von Sperling, M (2006) Introdução à qualidade das águas e ao tratamento de esgotos. Belo Horizonte, DESA-UFMG

von Sperling, M. (1997) Princípios do tratamento biológico de águas residuárias: Lodos Ativados. Belo Horizonte, DESA-UFMG.

Werner, M.; Kayser, R. (1991) Denitrification with biogas as external carbon source. Water Science and Technology 23,701-708

Zhang, T.C.; Lampe, D.G. (1999) Sulfur: limestone autotrophic denitrification process for treatment of nitrate-contaminated water: batch experiments. Water Research 33, 599-608. 


\section{Material e Métodos}

"É assim o sábio orgulhoso: traz a pequenina migalha, apanhada no caminho, e julga conduzir o próprio Himalaia. A ciência é uma grande montanha de açúcar; dessa montanha só conseguimos retirar insignificantes pedacinhos." 


\subsection{APARATO EXPERIMENTAL}

\subsubsection{CONFIGURAÇÃO UASB+RAALF}

O sistema experimental de bancada constituiu-se de um Reator Anaeróbio de Manta de Lodo (UASB), associado a um Reator Aeróbio-Anóxico de Leito Fixo (RAALF). No reator UASB, ocorreu a remoção de parte da matéria orgânica carbonácea e, no RAALF, o pós-tratamento do efluente oriundo do reator UASB, com a remoção de matéria orgânica carbonácea residual e compostos de nitrogênio.

O UASB foi operado adotando-se parâmetros típicos para esse tipo de reator quando utilizado no tratamento de esgoto sanitário, como, por exemplo, Tempo de Detenção Hidráulica $(\theta \mathrm{h})$ de $8 \mathrm{~h}$ e Velocidade Ascensional $\left(\mathrm{V}_{\text {asc }}\right)$ de $0,12 \mathrm{~m} \mathrm{~h}^{-1}$. Na Tabela 1, podem ser verificadas as características principais de ambos os reatores e, na Figura 1, pode ser observado o esquema do sistema.

Tabela 1: Características construtivas do sistema UASB-RAALF

\begin{tabular}{|c|c|c|c|}
\hline \multicolumn{2}{|l|}{ UASB } & \multicolumn{2}{|l|}{ RAALF } \\
\hline Característica construtiva & Valor & Característica construtiva & Valor \\
\hline Comprimento total (L) & $120 \mathrm{~cm}$ & Comprimento total (L) & $100 \mathrm{~cm}$ \\
\hline Comprimento útil $\left(\mathrm{L}_{\mathrm{U}}\right)$ & $94 \mathrm{~cm}$ & Comprimento útil $\left(\mathrm{L}_{\mathrm{U}}\right)$ & $85 \mathrm{~cm}$ \\
\hline Diâmetro (D) & $15 \mathrm{~cm}$ & Diâmetro (D) & $9,5 \mathrm{~cm}$ \\
\hline Relação L/D & 8 & Relação L/D & 10,5 \\
\hline Relação $\mathrm{L}_{\mathrm{U}} / \mathrm{D}$ & 6,3 & Relação $\mathrm{L}_{\mathrm{U}} / \mathrm{D}$ & 9 \\
\hline \multirow[t]{2}{*}{ Volume total (V) } & $21,2 \mathrm{~L}$ & Volume total (V) & $7,1 \mathrm{~L}$ \\
\hline & & Volume da câmara aeróbia $\left(\mathrm{V}_{\mathrm{Aer}}\right)$ & $2,5 \mathrm{~L}$ \\
\hline \multirow[t]{2}{*}{ Volume útil (Vu) } & $16,6 \mathrm{~L}$ & Volume da câmara anóxica $\left(\mathrm{V}_{\mathrm{Ano}}\right)$ & \\
\hline & & & $3,5 \mathrm{~L}$ \\
\hline
\end{tabular}




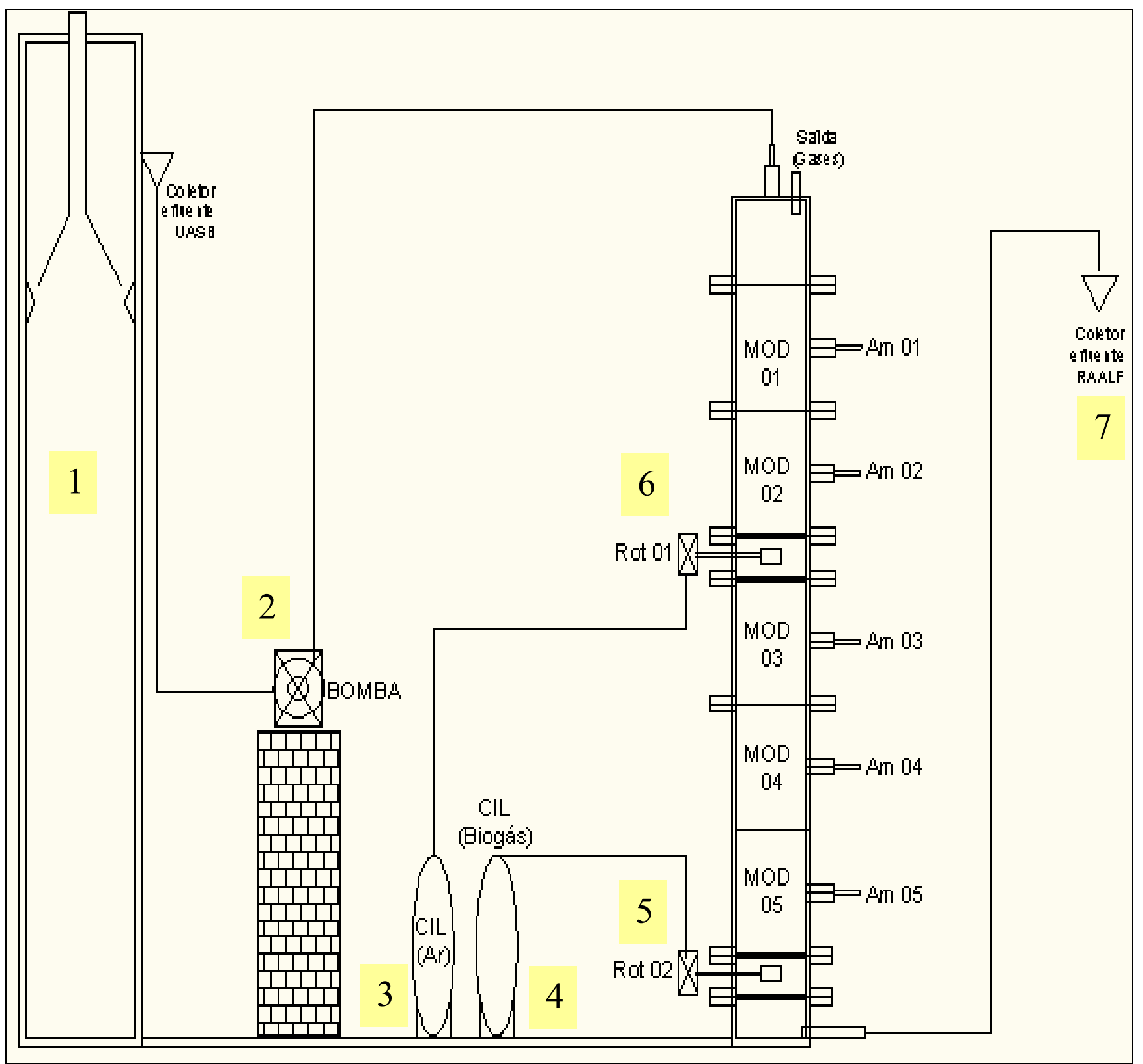

Figura 1: Configuração experimental

Legenda numérica. 1: Reator UASB; 2: Bomba peristáltica; 3: Cilindro de ar comprimido; 4: Cilindro de biogás sintético; 5: Rotâmetro (linha de ar comprimido); 6: Rotâmetro (linha de biogás sintético); 7 :

Coletor do efluente ao RAALF.

Legenda abreviações: MOD (módulos do RAALF), sendo MOD 1-2 referentes à câmara aeróbia e MOD 3-5 referentes à câmara anóxica; Am (amostradores do RAALF), sendo Am 1-2 referentes à câmara aeróbia e Am 3-5 referentes à câmara anóxica 


\subsubsection{MATERIAL SUPORTE}

É desejável que o material suporte apresente características como alta porosidade, boa resistência mecânica e resistência à corrosão. Por estas razões, a espuma de poliuretano vem sendo utilizada com freqüência em reatores de leito fixo tratando esgoto sanitário, tanto sob condições anaeróbias (Zaiat, 1997), como aeróbias (Vieira, 2001) ou combinadas (aeróbio-anaeróbio) (Fazolo, 2003). Ademais, trata-se de um material suporte que permite a aderência de biomassa anaeróbia (Ribeiro et al., 2005) e aeróbia de grande diversidade.

Portanto, os dois compartimentos foram preenchidos com cubos de espuma de poliuretano, cujas características estão descritas na Tabela 2.

Tabela 2: Características físicas da espuma de poliuretano

\begin{tabular}{cc}
\hline Característica & Dimensão \\
\hline Aresta & $5 \mathrm{~mm}$ \\
Densidade & $23 \mathrm{~kg} \mathrm{~m}^{-1}$ \\
Porosidade & $95 \%$ \\
Diâmetro médio dos poros & $543 \mu \mathrm{m}$ \\
\hline
\end{tabular}

\subsection{3 ÁGUA RESIDUÁRIA}

O sistema experimental foi alimentado com esgoto sanitário de origem predominantemente doméstica, proveniente do Campus 2 da USP São Carlos, bem como de parte de bairro residencial adjacente. Com base na definição apresentada por Jordão e Pessoa (2005), que se assenta sobre a concentração de sólidos, o esgoto sanitário utilizado pode ser classificado como médio na época seca, tendendo a fraco na época de chuvas (dados não apresentados). 


\subsubsection{DOADORES DE ELÉTRONS PARA A DESNITRIFICAÇÃO}

O biogás produzido em reator anaeróbio tratando água residuária doméstica é constituído de 70-80\% de metano, sendo que o restante é uma mistura de nitrogênio, dióxido de carbono, vapor de água e uma pequena fração de $\mathrm{H}_{2} \mathrm{~S}$ e, ainda, traços de outros gases (Pradyot, 2002).

Os doadores de elétrons aplicados com a finalidade de desnitrificar o efluente oriundo do reator UASB foram o sulfeto de hidrogênio e o metano, de origem sintética, fornecidos por meio de cilindro da Empresa White Martins S/A.

O biogás sintético foi injetado no sistema de maneira a prover um tempo de residência em leito vazio do gás (TRLV) de aproximadamente 5 minutos, considerando apenas as dimensões da câmara desnitrificante.

As propriedades químicas desses compostos, bem como sua aplicação no sistema, estão explicitadas na Tabela 3. A composição do biogás está descrita na Tabela 4.

Tabela 3: Propriedades químicas dos doadores de elétrons utilizados para a desnitrificação

\begin{tabular}{ccc}
\hline Propriedade & Sulfeto de hidrogênio & Metano \\
\hline Formula molecular & $\mathrm{H}_{2} \mathrm{~S}$ & $\mathrm{CH}_{4}$ \\
Massa molar & $34,082 \mathrm{~g} \mathrm{~mol}^{-1}$ & $16,042 \mathrm{~g} \mathrm{~mol}^{-1}$ \\
Aparência & Incolor & Incolor \\
Densidade & $1,363 \mathrm{~g} \mathrm{~L}^{-1}($ gás $)$ & $0.717 \mathrm{~kg} \mathrm{~m}^{-3}$ (gás) \\
Solubilidade em água & $40 \mathrm{~g} \mathrm{~L}^{-1}\left(20^{\circ} \mathrm{C}\right)$ & $415 \mathrm{~kg} \mathrm{~m}^{-3}$ (líquido) \\
Acidez $\left(\mathrm{pK}_{\mathrm{a}}\right)$ & 6.89 & $35 \mathrm{mg} \mathrm{L}^{-1}\left(17^{\circ} \mathrm{C}\right)$ \\
& $19 \pm 2$ & -
\end{tabular}

Fonte: Pradyot (2002) 
Tabela 4: Composição média do biogás sintético

\begin{tabular}{ccc}
\hline \multirow{2}{*}{ Composto } & \multicolumn{2}{c}{ Concentração $\left(\mathrm{g} \mathrm{m}^{-3}\right)$} \\
\cline { 2 - 3 } & Condição 2* & Condição 3** \\
\hline $\mathrm{H}_{2} \mathrm{~S}$ & 50 & 0,5 \\
$\mathrm{CH}_{4}$ & 380 & 380 \\
$\mathrm{CO}_{2}$ & Gás de arraste & Gás de arraste
\end{tabular}

*Condição 2: Injeção de gás, variação de $\theta$ h entre 7,5 e 2,5 h **Condição 3: Injeção de biogás, $\theta$ h de 5 h.

\subsubsection{CARACTERIZAÇÃO HIDRODINÂMICA}

Com a finalidade de prover uma melhor compreensão do padrão de escoamento do RAALF, foram conduzidos estudos hidrodinâmicos os quais foram realizados sob condições abióticas e utilizando a configuração experimental apresentada na Figura 2.

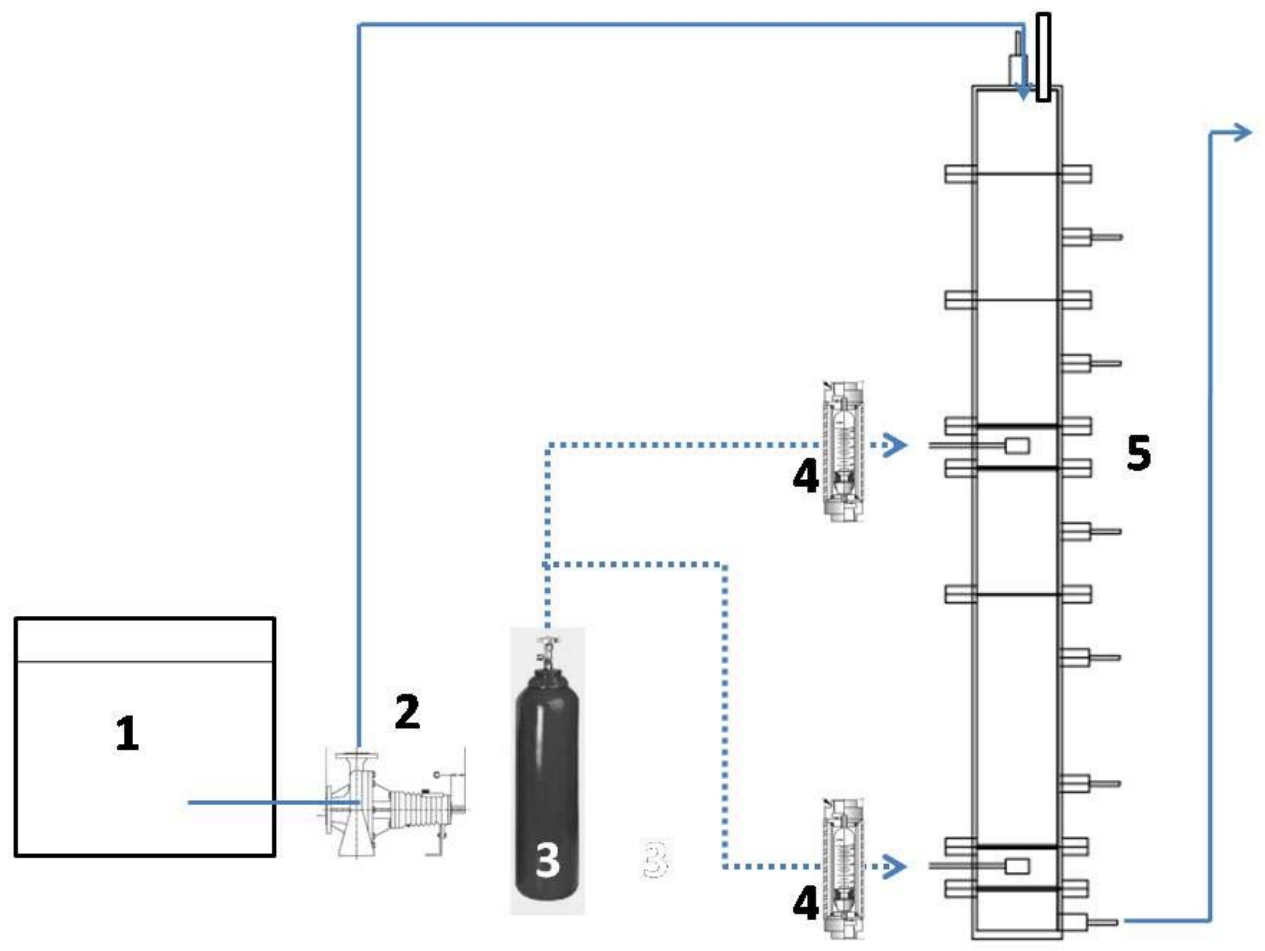

Figura 2: Esquema da configuração experimental utilizada nos ensaios hidrodinâmicos.

1: Tanque de água; 2: Bomba peristáltica; 3: Cilindro de ar comprimido; 4: Rotâmetros; 5: 
Foram utilizados quatro diferentes tipos de traçadores: cloreto de sódio, azul de bromofenol, eosina Y e dextrana azul. Tais compostos químicos foram escolhidos devido às suas diferentes características químicas (Tabela 5), bem como pelo fato de que são comumente utilizados para avaliar o padrão de escoamento em reatores tratando água residuária. Esses traçadores foram utilizados por diferentes autores (Jimenez et al., 1998; De Nardi, 1997; De Nardi et al., 1999; Lima, 2001), em diferentes configurações de reatores, em estudos prévios.

As amostras efluentes foram coletadas em intervalos de tempo regulares, de acordo com o $\theta \mathrm{h}$ experimental. O tempo total dos ensaios foi o equivalente a 3 vezes o $\theta$ h teórico, a fim de garantir tempo suficiente para a recuperação dos traçadores.

Tabela 5: Características principais dos traçadores

\begin{tabular}{ccc}
\hline Traçador & $\begin{array}{c}\text { Massa molecular } \\
\left(\mathrm{g} \mathrm{mol}^{-1}\right)\end{array}$ & $\begin{array}{c}\text { Comprimento de onda }(\lambda) \\
(\mathrm{nm})\end{array}$ \\
\hline Cloreto de sódio & 58 & - \\
Eosina Y & 692 & 540 \\
Azul de bromofenol & 669 & 310 \\
Dextrana azul & $2 \times 10^{6}$ & 650 \\
\hline
\end{tabular}

Em vista desse fato, o estudo hidrodinâmico proposto nesta pesquisa pode permitir a comparação entre diferentes sistemas. A escolha do traçador foi baseada na solubilidade desses compostos, com particular atenção ao fato de que o procedimento utilizado pudesse permitir a detecção dos mesmos (comprimento de onda) nas análises colorimétricas.

O cloreto de sódio foi determinado medindo-se a condutividade do íon cloreto $\left(\mathrm{Cl}^{-}\right)$. Para este propósito, foi utilizado um aparato consistindo de uma sonda para medição da condutividade de $\mathrm{Cl}^{-}$, acoplada a um transdutor de CBL que, por sua vez, foi conectado a uma calculadora da Texas Instruments TM. 
O experimento com traçadores foi realizado através de vários testes, sob diferentes condições, como com ou sem injeção de ar. Tais estudos foram conduzidos a um $\theta$ h de aproximadamente 1 hora. Depois, a dextrana azul foi avaliada para $\theta$ h de 3 e 5 horas, respectivamente, a fim de promover uma melhor compreensão do impacto de diferentes velocidades, descensionais principalmente sobre os parâmetros dos modelos.

O método de injeção aplicado foi do tipo estímulo-resposta (pulso). Algumas precauções foram tomadas para garantir que a injeção do traçador fosse a mais próxima possível de um pulso ideal. O volume de injeção do traçador $(50 \mathrm{~mL})$ foi muito baixo quando comparado com o volume total do reator $(7,1 \mathrm{~L})$, e o tempo de injeção (7 s) foi muito curto quando comparado com o $\theta$ h aplicado $(1,3$ e 5 horas respectivamente). Na Figura 3 está apresentada uma fotografia do RAALF durante um dos ensaios hidrodinâmico realizados.

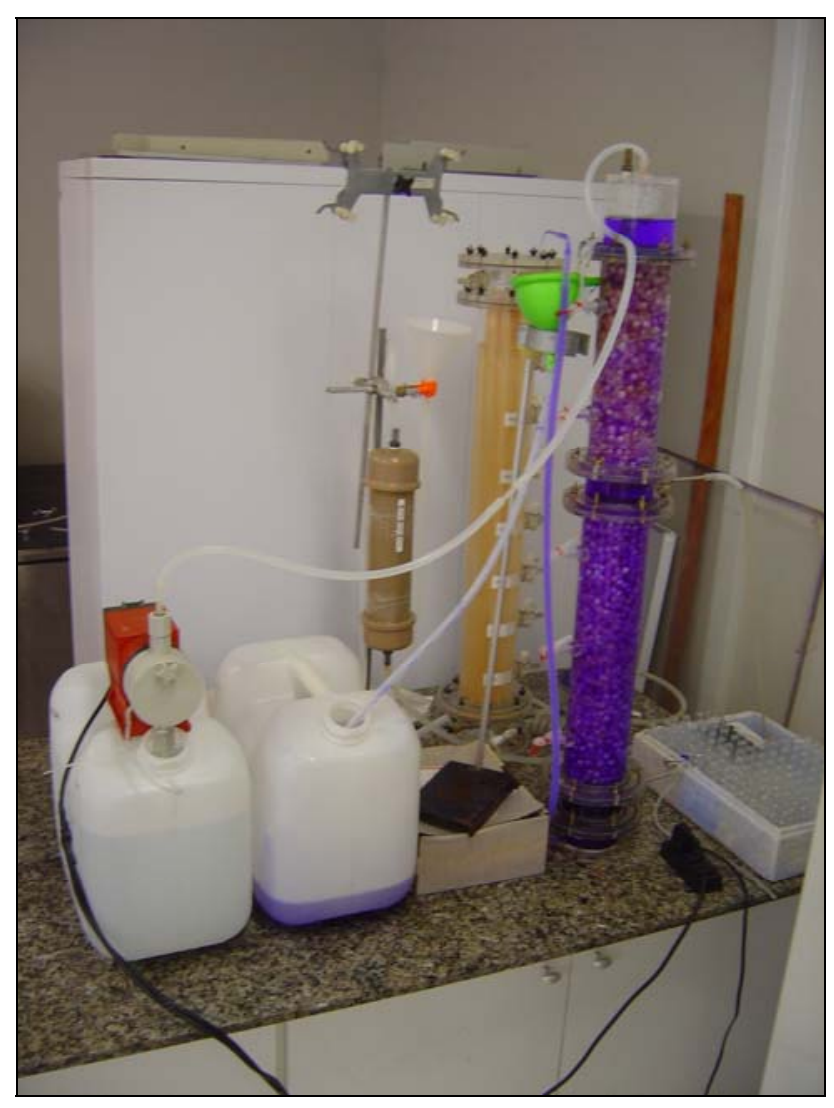

Figura 3: Fotografia do RAALF durante um dos ensaios hidrodinâmicos 
44

\subsection{PROCEDIMENTO EXPERIMENTAL}

\subsubsection{MICRORGANISMOS E INOCULAÇÃO}

O inóculo aplicado na câmara nitrificante foi oriundo de tanques de lodos ativados tratando esgoto sanitário da empresa Wolksvagen do Brasil S.A., localizada em São Carlos. O procedimento de inoculação consistiu em submergir o material suporte no lodo aeróbio sem acondicionamento e deixálo em repouso pelo período de 2 horas. Os exames de microscopia ótica apontaram grande diversidade de microrganismos, especialmente àqueles com morfologias semelhantes às bactérias nitrificantes.

Na câmara desnitrificante, foi aplicado lodo oriundo (também sem acondicionamento) de reator UASB tratando efluente de abatedouro de aves da empresa DACAR S/A, localizada em Tietê, SP. O procedimento de adesão da biomassa anaeróbia ao material suporte foi baseado na metodologia proposta por Zaiat (1997).

Na Figura 4 podem ser observadas algumas das morfologias presentes nas amostras retiradas dos inóculos. 


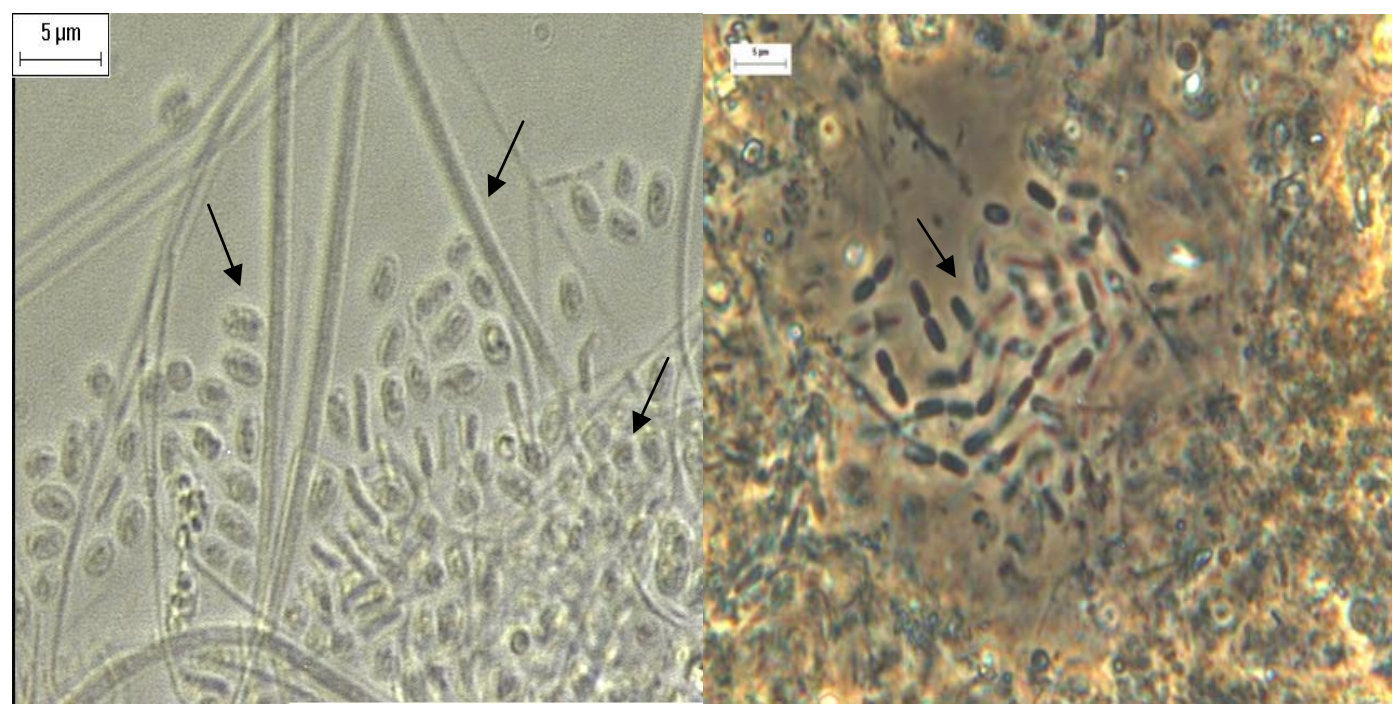

(a)

(b)

Figura 4: Lodo aeróbio retirado de tanques de Lodos Ativados (cocos, bacilos e filamentos) (a) e Lodo anaeróbio retirado de Reator UASB tratando efluente de abatedouro de aves (preponderância de bacilos).

\subsubsection{CONDIÇÕES DE OPERAÇÃO}

O estudo foi dividido em 3 condições de operação, a saber:

- Condição 1: equilíbrio dinâmico da nitrificação;

- Condição 2: subdividida em 3 sub-condições, 2.1, 2.2 e 2.3, com injeção do biogás contendo metano e sulfeto de hidrogênio (380 $\mathrm{g} \mathrm{m}^{3}$ e $\left.50 \mathrm{~g} \mathrm{~m}^{3}\right)$, na qual variou-se o tempo de detenção hidráulico $(\theta \mathrm{h})$ entre 7,5 e 2,5 horas;

- Condição 3: com injeção do biogás contendo metano e sulfeto de hidrogênio $\left(380 \mathrm{~g} \mathrm{~m}^{3}\right.$ e $\left.0,5 \mathrm{~g} \mathrm{~m}^{3}\right)$, na qual foi empregado o $\theta$ h de 5 horas.

Para avaliação operacional e de desempenho do RAALF foram avaliados três $\theta$ h diferentes com o intuito de estabelecer a melhor condição operacional do reator. Com o aumento da vazão de 
46

esgoto (diminuição do $\theta$ h), esperou-se aumentar a velocidade de transferência de massa líquido-sólido, podendo resultar em efeitos positivos no desempenho global do processo.

$\mathrm{Na}$

Tabela 6 estão apresentadas as variáveis de operação das condições nas quais o trabalho foi subdividido.

Tabela 6: Condições de operação do RAALF

\begin{tabular}{|c|c|c|}
\hline Etapa & Subdivisão & Característica \\
\hline 1 & - & $\begin{array}{c}\text { Equilíbrio dinâmico da } \\
\text { nitrificação }\end{array}$ \\
\hline & 2.1 & $\begin{array}{c}\text { Injeção de gás } \\
\theta \mathrm{h}=7,5 \mathrm{~h}(3 \mathrm{~h} \text { aeróbia e } 4,5 \\
\text { anóxica })\end{array}$ \\
\hline 2 & 2.2 & $\begin{array}{c}\text { Injeção de gás } \\
\theta \mathrm{h}=5 \mathrm{~h}(2 \mathrm{~h} \text { aeróbia e } 3 \\
\text { anóxica })\end{array}$ \\
\hline & 2.3 & $\begin{array}{c}\text { Injeção de gás } \\
\theta \mathrm{h}=2,5 \mathrm{~h}(1 \mathrm{~h} \text { aeróbia e } 1,5 \\
\text { anóxica })\end{array}$ \\
\hline 3 & - & $\begin{array}{c}\text { Injeção de gás } \\
\theta \mathrm{h}=5 \mathrm{~h}(2 \mathrm{~h} \text { aeróbia e } 3 \\
\text { anóxica })\end{array}$ \\
\hline
\end{tabular}




\subsubsection{MONITORAMENTO}

A avaliação do comportamento da fase líquida do RAALF foi feita monitorando-se os parâmetros operacionais por meio de análise de amostras coletadas no afluente ao reator, na saída da câmara aeróbia e efluente ao reator. Com relação à fase gasosa, foram realizadas análises do efluente gasoso no topo do reator. A fase sólida foi monitorada por meio de análises gravimétricas e a composição da superfície do material suporte foi realizada por meio da análise de espectroscopia de dispersão de energia de raios-X.

Os perfis espaciais foram realizados a partir da tomada de amostras ao longo de diferentes pontos de amostragem, instalados em diferentes relações L/D do reator, a saber $(0,8 ; 2,4 ; 3,4 ; 4,5 ; 5,5$; $7,1 ; 10)$.

\subsubsection{Análises físico-químicas}

Com relação aos parâmetros monitorados, à freqüência de amostragem e às análises, os procedimentos adotados foram de acordo com a natureza e utilidade das medidas. Na Tabela 7 podem ser verificados os parâmetros monitorados, o método de análise utilizados e a freqüência de determinação. 
Tabela 7 : Parâmetros e freqüência de análises

\begin{tabular}{|c|c|c|}
\hline Parâmetro & Freqüência & Método \\
\hline Temperatura & $2 \times /$ semana & - \\
\hline $\mathrm{pH}$ & $2 \times /$ semana & Potenciométrico \\
\hline pOR & Eventual & Potenciométrico \\
\hline OD & $2 \mathrm{x} /$ semana & Potenciométrico \\
\hline Alcalinidade total & $2 \mathrm{x} /$ semana & Titulométrico \\
\hline $\mathrm{DQO}_{\mathrm{T}}, \mathrm{DQO}_{\mathrm{F}}$ & $2 \mathrm{x} /$ semana & Espectrofotométrico \\
\hline $\mathrm{N}-\mathrm{NH}_{4}{ }^{+}$ & $2 \mathrm{x} /$ semana & $\begin{array}{c}\text { Titulométrico/ Colori- } \\
\text { espectro }\end{array}$ \\
\hline $\mathrm{N}-\mathrm{NO}^{-2}, \mathrm{~N}-\mathrm{NO}^{-3}$ & $2 \mathrm{x} /$ semana & Colori-espectro \\
\hline STD & $2 \mathrm{x} /$ semana & Espectrofotométrico \\
\hline $\mathrm{SO}_{4}{ }^{2-}$ & $2 \times /$ semana & Espectrofotométrico \\
\hline $\mathrm{CH}_{4} \mathrm{e} \mathrm{CO}_{2}$ & $2 \mathrm{x} /$ semana & $\begin{array}{c}\text { Cromatográfico (item } \\
4.3 .2 .2 \text { ) }\end{array}$ \\
\hline $\mathrm{H}_{2} \mathrm{~S}$ & $2 \mathrm{x} /$ semana & Colorimétrico (item 4.3.2.3) \\
\hline Ácidos orgânicos e álcoois & $2 \times /$ semana & $\begin{array}{c}\text { Cromatográfico(item } \\
4.3 .2 .4)\end{array}$ \\
\hline $\begin{array}{l}\text { Composição química da } \\
\text { superfície do material } \\
\text { suporte }\end{array}$ & Eventual & $\begin{array}{l}\text { Espectroscopia por } \\
\text { dispersão de energia de } \\
\text { raios-X }(\mathrm{EDX}) *\end{array}$ \\
\hline
\end{tabular}

[*] É utilizada para caracterizar quimicamente uma amostra. É uma das variantes da espectroscopia fluorescente de raios-X, que se assenta sobre a investigação de uma amostra por meio de interações entre a radiação eletromagnética e a matéria, analisando raios-X emitidos pela matéria em resposta ao fato de serem atingidas com partículas carregadas. Sua capacidade de caracterização é, em grande parte, devida ao princípio fundamental de que cada elemento possui uma única estrutura atômica. 


\subsubsection{Metano e dióxido de carbono - Cromatografia gasosa}

A composição dos gases foi monitorada por cromatografia gasosa por meio de um cromatógrafo Gow-Mac com detector de condutividade térmica e coluna "Porapak Q" (2m x 1/4 “ - 80 a 100 mesh). O gás de arraste foi o hidrogênio a $1 \mathrm{~mL} \mathrm{~s}^{-1}$.

\subsubsection{Sulfeto de hidrogênio - Azul de metileno}

A análise de sulfeto baseou-se no método do azul de metileno, com alterações para coleta do sulfeto em fase gasosa, que consiste no borbulhamento do gás em um frasco contendo certo volume de solução de $\mathrm{NaOH}(\mathrm{pH}$ 13). O princípio do método é a reação do sulfeto de hidrogênio com oxalato de N-dimetil-p-fenilenodiamina para formar azul de metileno. A intensidade da cor azul é proporcional a concentração de sulfeto. Para a determinação da concentração de sulfeto, converteu-se, em um primeiro momento, a concentração encontrada no espectrofotômetro $\left(\mathrm{C}_{\mathrm{E}}, \mathrm{mg} \mathrm{L}^{-1}\right)$ para a concentração real da amostra $\left(\mathrm{C}, \mathrm{mg} \mathrm{L}^{-1}\right)$, conforme pode ser verificado na Equação 15:

$$
C=\frac{C_{E} D V}{Q t}
$$

Equação 15

Em que: $\mathrm{C}$ é a concentração real da amostra; $\mathrm{C}_{\mathrm{E}}$ é a concentração lida no espectrofotômetro (mg $\mathrm{L}_{-1}$ ); D é o fator de diluição da amostra (adimensional); $V_{L}$ é o volume da amostra (L); Q é a vazão da corrente gasosa $\left(\mathrm{L} \mathrm{h}^{-1}\right)$; t é o tempo de coleta da amostra (h).

Finalmente, a concentração obtida na Equação 15 foi inserida na Equação 16, para se determinar a concentração de $\mathrm{H}_{2} \mathrm{~S}$ em partes por milhão (ppm): 


$$
C_{\mathrm{H}_{2} \mathrm{~S}}=\mathrm{C} \frac{24,44}{\mathrm{molH}_{2} \mathrm{~S}}
$$

Equação 16

Em que: $\mathrm{C}_{2} \mathrm{~S}$ é a concentração do sulfeto de hidrogênio (ppm); C é a concentração calculada na Equação $4.1\left(\mathrm{mg} \mathrm{m}^{-3}\right) ; 24,44$ é o volume molar corrigido para $1 \mathrm{~atm}$ e $25^{\circ} \mathrm{C}\left(\mathrm{L} \mathrm{mol}^{-1}\right)$.

Maiores detalhes sobre este método podem ser encontrados em Pantoja Filho et al (2010).

\subsubsection{4 Álcoois e ácidos voláteis - Cromatografia gasosa de headspace}

A analise de alcoóis e ácidos voláteis foi realizada por cromatografia gasosa de headspace, utilizando um cromatógrafo Shimadzu GC2010, com um sistema de injeção automática e utilizando um detector de ionização de chama mantido à temperatura constante de $280^{\circ} \mathrm{C}$ e alimentado com gases de chama hidrogênio a $30 \mathrm{~mL} \mathrm{m^{-1 }}$ e ar sintético a $300 \mathrm{~mL} \cdot \mathrm{min}^{-1}$ e coluna Hewllet-Packard INNOWAX, de 30m x 25 mm e 0,25 um de espessura de filme.

A fase móvel utilizou hidrogênio como gás de arraste a uma vazão de 1,6 mL.min ${ }^{-1}$, sendo que o injetor foi mantido à temperatura constante de $250^{\circ} \mathrm{C}$ e a temperatura do forno seguiu a seguinte rampa: $35^{\circ} \mathrm{C}$ (na injeção da amostra) e uma taxa de $2{ }^{\circ} \mathrm{C} \min ^{-1}$ até $38^{\circ} \mathrm{C}$ seguido de uma taxa de aquecimento de $10^{\circ} \mathrm{C} \min ^{-1}$ até $75^{\circ} \mathrm{C}$, a seguir foi aplicada uma taxa de $35^{\circ} \mathrm{C}$ até atingir $120^{\circ} \mathrm{C}$ mantendo-se constante por 1 minuto, e por fim aplicada uma taxa de $35^{\circ} \mathrm{Cmin}^{-1}$ até atingir $170^{\circ} \mathrm{C}$ mantendo-se constante por 2 minutos. O gás de make - up foi nitrogênio a uma vazão de $30 \mathrm{~mL} \mathrm{~min}^{-1}$.

O preparo da amostra consistiu na adição de $1 \mathrm{~g} \mathrm{NaCl} ; 70 \mathrm{uL}$ de solução de isobutanol $1 \mathrm{~g} \mathrm{~L}^{-1}$ (padrão interno para acetona e alcoóis); $10 \mathrm{uL}$ de solução de ácido crotônico $700 \mathrm{mgL}^{-1}$ (padrão interno para ácidos); $200 \mathrm{uL}$ de solução de $\mathrm{H}_{2} \mathrm{SO}_{4} 2 \mathrm{M}$; para cada $2 \mathrm{~mL}$ de amostra. $\mathrm{O}$ tempo de aquecimento de amostra foi de $13 \min$ a $100^{\circ} \mathrm{C}$ e o volume injetado foi de $400 \mathrm{uL}$ pela seringa aquecida a $100^{\circ} \mathrm{C}$. 


\subsubsection{Vazão de esgoto}

$$
Q=\frac{V o l}{t}
$$

\section{Equação 17}

Em que: Q é a vazão de entrada do líquido no reator $\left(\mathrm{L} \mathrm{h}^{-1}\right)$, Vol é volume de líquido medido em um dado intervalo de tempo (L), té tempo $\left(\mathrm{h}^{-1}\right)$.

\subsubsection{Tempo de detenção hidráulico}

$$
\theta h=\frac{V o l}{Q}
$$

Equação 18

Em que: Oh é o tempo de detenção hidráulico (h); Vol útil do RAALF ( $\mathrm{m}^{3}$ ); Q é a vazão de entrada do líquido no reator $\left(\mathrm{m}^{3} \mathrm{~h}^{-1}\right)$.

\subsubsection{Eficiência de remoção de matéria orgânica carbonácea}

$$
E R=\frac{C_{E} D Q O-C_{S} D Q O}{C_{E} D Q O} .100
$$

Equação 19

Em que: ER é a eficiência de remoção de matéria orgânica carbonácea expressa pro meio de DQO (\%), $\mathrm{C}_{\mathrm{E}} \mathrm{DQO}$ é a concentração afluente de matéria orgânica $\left(\mathrm{mg} \mathrm{L}^{-1}\right)$, Cs DQO é a concentração efluente de matéria orgânica $\left(\mathrm{mg} \mathrm{L}^{-1}\right)$. 


\subsubsection{Eficiência de remoção de nitrogênio amoniacal}

$$
E R=\frac{C_{E}\left(N-N H_{4}^{+}\right)-C_{S}\left(N-N H_{4}^{+}\right)}{C_{E}\left(N-N H_{4}^{+}\right)} .100
$$

Equação 20

Em que: ER é a eficiência de remoção do nitrogênio na forma de nitrogênio amoniacal (\%), $\mathrm{C}_{\mathrm{E}} \mathrm{NH}_{4}{ }^{+}$é a concentração afluente do nitrogênio na forma de nitrogênio amoniacal $\left(m g \mathrm{~L}^{-1}\right), \mathrm{C}_{\mathrm{S}} \mathrm{NH}_{4}{ }^{+} \mathrm{é}$ a concentração efluente do nitrogênio na forma de nitrogênio amoniacal ( $\left.\mathrm{mg} \mathrm{L}^{-1}\right)$, Q é a vazão de entrada do líquido no reator $\left(\mathrm{L} \mathrm{h}^{-1}\right)$.

\subsubsection{Eficiência de remoção de nitrato}

$$
E R=\frac{C_{E}\left(N-N O_{3}^{-}\right)-C_{S}\left(N-N O_{3}^{-}\right)}{C_{E}\left(N-N O_{3}^{-}\right)} .100
$$

Equação 21

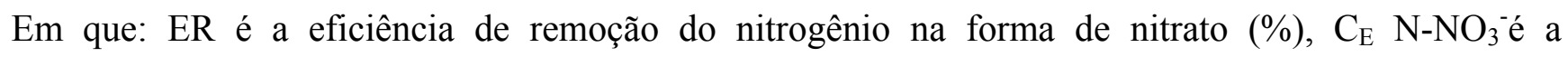
concentração afluente do nitrato $\left(\mathrm{mg} \mathrm{L}^{-1}\right), \mathrm{C}_{\mathrm{S}} \mathrm{N}-\mathrm{NO}_{3}{ }^{-}$é a concentração efluente do nitrato $\left(\mathrm{mg} \mathrm{L}^{-1}\right)$.

\subsubsection{Eficiência de remoção de nitrito}

$$
E R=\frac{C_{E}\left(N-N O_{2}^{-}\right)-C_{S}\left(N-N O_{2}^{-}\right)}{C_{E}\left(N-N O_{2}^{-}\right)} .100
$$

Equação 22

Em que: ER é a eficiência de remoção do nitrogênio na forma de nitrito (\%), $\mathrm{C}_{\mathrm{E}} \mathrm{N}-\mathrm{NO}_{2}{ }^{-}$é a concentração afluente do nitrato $\left(\mathrm{mg} \mathrm{L}^{-1}\right), \mathrm{C}_{\mathrm{S}} \mathrm{N}-\mathrm{NO}_{2}{ }^{-e ́}$ a concentração efluente do nitrito $\left(\mathrm{mg} \mathrm{L}^{-1}\right)$. 


\subsubsection{Taxa de desnitrificação}

$$
\text { TxDesn }=\frac{Q \cdot\left(C_{E}\left(N-N O_{3}^{-}\right)-\left(C_{S}\left(N-N O_{3}^{-}\right)\right)\right.}{V o l}
$$

Equação 23

Em que: TxDesn é a taxa de desnitrificação da câmara anóxica $\left(\mathrm{g} \mathrm{m}^{-3} \mathrm{~d}^{-1}\right), \mathrm{C}_{\mathrm{E}} \mathrm{N}-\mathrm{NO}_{3}{ }^{-}$é a concentração afluente à câmara anóxica do nitrato $\left(\mathrm{g} \mathrm{m}^{-3}\right), \mathrm{C}_{\mathrm{S}} \mathrm{N}-\mathrm{NO}_{3}{ }^{-}$é a concentração efluente à câmara anóxica do nitrato $\left(\mathrm{g} \mathrm{m}^{-3}\right)$, Q é a vazão de entrada do líquido no reator $\left(\mathrm{m}^{-3} \mathrm{~d}^{-1}\right)$, Vol é o volume da câmara anóxica.

\subsubsection{Eficiência de remoção de gases}

O desempenho do reator, quanto à sua habilidade de remover gases, será reportado como eficiência de remoção (ER) (\%), definido na Equação 24, como segue:

$$
E R=\frac{\operatorname{Qmistura}\left(C_{E G}-C_{S G}\right)}{C_{E G}}
$$

Equação 24

Em que: ER é a eficiência de remoção do composto gasoso de interesse, $\mathrm{C}_{\mathrm{E}}$ é a concentração afluente do composto gasoso de interesse $\left(\mathrm{g} \mathrm{m}^{-3}\right)$, Cs é a concentração efluente desse composto $\left(\mathrm{g} \mathrm{m}^{-3}\right)$, Q é a vazão da mistura gasosa $\left(\mathrm{m}^{-3} \mathrm{~h}^{-1}\right)$. 


\subsubsection{ANÁLISE MATEMÁTICA DOS ENSAIOS HIDRODINÂMICOS}

A análise dos dados dos ensaios hidrodinâmicos incluiu a determinação dos termos definidos na Tabela 8 e na Equação 25, Equação 26 eEquação 27, de acordo com Levenspiel (2000). Na Tabela 8 pode ser observado o sumário de definições das variáveis utilizadas nos modelos uniparamétricos, a fim de se obter a distribuição do tempo de residência $\left(\mathrm{E}_{\theta}\right)$ como função do tempo adimensional $(\theta)$.

Tabela 8: Definição das variáveis utilizadas para se obter a função de distribuição do tempo de residência $\left(\mathrm{E}_{\theta}\right)$ pelo tempo de residência médio adimensional $(\theta)$.

\begin{tabular}{|c|c|}
\hline Variável & Definição \\
\hline $\mathrm{E}_{\mathrm{i}}$ & $\frac{C_{i}}{S}$ \\
\hline $\mathrm{S}$ & $\int_{0}^{\circ o o} C d t$ \\
\hline$\overline{\theta h}$ & $\int_{0}^{o o} \frac{t C(t) d t}{C(t) d t}$ \\
\hline$\theta$ & $\frac{t}{\overline{\theta h}}$ \\
\hline $\mathrm{E}_{\theta}$ & $\overline{\theta h} E_{i}$ \\
\hline$\sigma^{2}$ & $\int_{0}^{o o} \frac{(t-\overline{\theta h})^{2} C(t) d t}{C(t) d t}$ \\
\hline$\sigma_{\theta}^{2}$ & $\frac{\sigma^{2}}{\overline{\theta h}}$ \\
\hline $\mathrm{M}_{\mathrm{rec}}$ & $\int_{0}^{o o} Q C(t) d t$ \\
\hline
\end{tabular}


Embora outros métodos de análises estejam disponíveis, os modelos de tanques de mistura perfeita em séries (N-CSTR) e o de dispersão axial (MDA) foram escolhidos por sua simplicidade e aplicabilidade geral. Estes dois modelos têm sido utilizados frequentemente em engenharia bioquímica e permitem, dessa forma, a comparação entre diferentes configurações de reatores.

O modelo N-CSTR é aplicado a reatores não ideais e consiste no equacionamento da resposta de um sistema de tanques de mistura perfeita em série, no qual o fluido escoando de um tanque para o outro. O modelo MDA é caracterizado considerando-se que um processo similar à difusão ocorre em reatores cujas características se aproximam do padrão de escoamento pistonado (Levenspiel, 2000).

Estes modelos foram ajustados às curvas experimentais. Tais características do modelo podem ser verificadas por parâmetros únicos, tais como o grupo adimensional $(\mathrm{D} / \mu \mathrm{L})$ para baixa e alta dispersão, ou o número $(\mathrm{N})$ de tanques ideais de mistura perfeita em série do modelo N-CSTR. Todos os parâmetros foram estimados a partir da variância dos dados-resposta apresentados nas Equação 2527, conforme segue:

- Modelo de Baixa dispersão:

$$
E_{0}=\frac{1}{\sqrt{4 \pi\left(\frac{D}{\mu L}\right)}} \exp \left[-\frac{(1-\theta)^{2}}{4\left(\frac{D}{\mu L}\right)}\right], \text { com parâmetro } \sigma_{\theta}^{2}=2\left(\frac{D}{\mu L}\right)
$$

Equação 25

- Modelo de Alta dispersão:

$$
E_{0}=\frac{1}{\sqrt{4 \pi\left(\frac{D}{\mu L}\right)}} \exp \left[-\frac{(1-\theta)^{2}}{4 \theta\left(\frac{D}{\mu L}\right)}\right], \text { com parâmetro } \sigma_{\theta}^{2}=2\left(\frac{D}{\mu L}\right)+8\left(\frac{D}{\mu L}\right)^{2}
$$

Equação 26 
- Modelo de N-CSTR em série:

$$
E_{0}=\frac{N(N \theta)^{N-1}}{(N-1) !} \exp [-N \theta], \text { com parâmetro } N=\frac{1}{\sigma_{\theta^{2}}}
$$

Equação 27

\subsubsection{ESTUDOS MICROBIOLÓGICOS}

Os estudos microbiológicos realizados no RAALF foram feitos com intuito de se compreender melhor e complementar as informações sobre as transformações biológicas ocorridas no sistema. Foram retiradas amostras em todas as condições de operação do sistema.

Como metodologia geral para extração das amostras imobilizadas nas espumas foi utilizada aquela descrita em Daniel (2005) e Cuba (2008), respectivamente.

\subsubsection{Número mais provável}

\subsection{Microrganismos nitrificantes}

Para a determinação das bactérias nitrificantes (oxidadoras de $\mathrm{N}_{-} \mathrm{NH}_{4}{ }^{+}$e oxidadoras de $\mathrm{N}$ $\mathrm{NO}_{2}-$ ), utilizou-se a técnica do número mais provável (NMP), modificada por Schimdt e Belser (1984), adaptada por Marchetto (2001) para amostras de esgoto sanitário. A preparação dos meios de cultura, tanto para as oxidadoras de $\mathrm{N}_{-} \mathrm{NH}_{4}{ }^{+}$, quanto para as oxidadoras de $\mathrm{N}_{-} \mathrm{NO}_{2^{-}}$, bem como os procedimentos de inoculação e incubação, seguiram a metodologia descrita em Mendonça (2002).

O NMP foi obtido a partir do resultado positivo nos tubos de maior diluição, conforme Alexander (1982), sendo o resultado expresso em número de bactérias por grama de sólidos voláteis. 
4.2.6.1.2 Microrganismos desnitrificantes

- Desnitrificantes totais

O número mais provável de bactérias desnitrificantes foi determinado através da técnica do NMP modificado por Tiedje (1982), adaptada por Marchetto (2001) para amostras de esgoto sanitário. O meio utilizado foi o do tipo genérico (Nutrient Broth), seguindo metodologia descrita em Mendonça (2002).

Os procedimentos de inoculação e incubação utilizados nestes ensaios foram similares aos utilizados no ensaio de NMP para bactérias nitrificantes.

- Desnitrificantes autotróficos

O número mais provável de bactérias desnitrificantes autotróficas foi determinado tendo como base a metodologia desenvolvida por Eckford e Fedorak (2005).

\subsection{Microrganismos metanotróficos}

Para os ensaios de NMP de microrganismos metanotróficos, foi utilizada a metodologia descrita por Cuba (2008). O meio de cultura utilizado neste trabalho foi o adaptado por Cuba (2008), a partir de trabalho realizado por Eisentraeger et al. (2001). 


\subsubsection{Visualização das morfologias}

\subsection{Microscopia ótica}

A fim de se verificar a existências das morfologias típicas presentes nos processos de interesse, foram coletadas amostras ao longo do período operacional e observadas ao microscópio óptico. O acompanhamento das morfologias foi realizado por exame microscópico de contraste de fase e fluorescência utilizando microscópio Leica DMLB, com sistema de captura de imagem Optronics e software Image Pro-Plus. A observação das morfologias foi realizada no Laboratório de Processos Biológicos do Departamento de Hidráulica e Saneamento da USP - São Carlos.

\subsection{Microscopia eletrônica de varredura}

Durante o período operacional foi realizada a visualização das morfologias presentes nos biofiltros por meio da análise de Microscopia Eletrônica de Varredura, em microscópio de propriedade do Instituto de Física da USP - São Carlos. O preparo das amostras para a microscopia eletrônica de varredura (MEV) A preparação das amostras baseou-se na técnica desenvolvida por Nation (1983), adaptada para biofilmes bacterianos por Araújo (2001), cujo procedimento está descrito a seguir. O processo de fixação foi feito com a inserção do meio suporte numa solução de glutaraldeido (2,5\% em tampão de fosfato) por $12 \mathrm{~h} \mathrm{a} 4{ }^{\circ} \mathrm{C}$. Decorridas $12 \mathrm{~h} \mathrm{o}$ material suporte passou por um processo de lavagem com uma solução tampão de fosfato 0,1 M com pH 7,3 durante $10 \mathrm{~min}$, e em seguida por um processo de secagem. Realizando-se uma seqüência de lavagens com soluções de etanol, cada uma de 10 minutos: $50 \%, 70 \%, 80 \%, 90 \%$, $95 \%$ e $100 \%$, sendo que na solução de $100 \%$ foram efetuadas 3 lavagens de 10 minutos cada. Após a secagem com o etanol foi utilizado HMDS (hexametildesilasani), efetuando-se 2 lavagens de $30 \mathrm{~s}$ cada, para o processo final de secagem. A amostra foi, então, fixada no suporte para microscopia 
eletrônica com esmalte base e então submetida ao banho de ouro. A análise microbiológica das morfologias pela via da microscopia eletrônica de varredura foi realizada utilizando-se um microscópio de varredura digital Zeiss DSM-960.

\subsubsection{Atividade desnitrificante}

Para realização deste ensaio, foram utilizados frascos de $500 \mathrm{~mL}$, inoculados com amostras da câmara anóxica do RAALF. Foram utilizados três grupos de reatores, sendo que cada grupo recebeu uma fonte diferente de elétrons, ou seja, o primeiro grupo recebeu metano, o segundo recebeu sulfeto e o terceiro recebeu acetato. A metodologia utilizada para a realização deste ensaio pode ser verificada com mais detalhes em Victoria (2006) e Moraes (2009).

\subsection{REFERÊNCIAS DO CAPÍTULO}

Alexander, M. (1982) Most probable number methods for microbial population, in Methods of soil analysis - Chemical and microbiological properties. Number 9, part 2, $2^{\mathrm{a}}$ ed., p.815-829. USA

Araújo, J.C. (2001) Acompanhamento da evolução do biofilme e caracterização química e biológica em reator de leito fluidificado tratando esgoto sanitário sintético. Tese (doutorado) Escola de Engenharia de São Carlos, Universidade de São Paulo, São Carlos.

Cuba, R.M.F. (2008) Utilização do metano como doador de elétrons para remoção de nitrogênio via nitrificação e desnitrificação em reator operado em bateladas seqüenciais. Tese (Doutorado) - Escola de Engenharia de São Carlos, Universidade de São Paulo, São Carlos.

Daniel, L.M.C. (2005) Remoção de nitrogênio via nitrito em reator operado em bateladas seqüenciais contendo biomassa imobilizada e aeração intermitente. São Carlos. 106 pg. Tese (Doutorado) - Escola de Engenharia de São Carlos, Universidade de São Paulo, São Carlos.

De Nardi, I.R. (1997) Influência das características do traçador nas curvas de distribuição de tempos de residência em reator anaeróbio horizontal de leito fixo. Dissertação (Mestrado) - Escola de Engenharia de São Carlos, Universidade de São Paulo, São Carlos.

De Nardi, I.R., Zaiat, M., Foresti, E. (1999) Influence of the tracer characteristics on hydrodynamic models of packed-bed bioreactors. Bioprocess Engineering. 21, 469-476. 
Eckford, R.E.; Fedorak, P.M. (2005). Applying a most probable number method for enumerating planktonic, dissimilatory, ammonium-producing, nitrate-reducing bacteria in oil field waters. Canadian Journal of Microbiology. 51 (8), 725.

Einsentraeger, A.; Klag, P.; Vannsbotter, B.; Heymann, E.; Dott, W. (2001) Denitrification of groundwater with methane as sole hydrogen donor. Water Research. 35(9), 2261-2267.

Fazolo, A. (2003) Nitrificação e desnitrificação em um único reator aeróbio-anaeróbio alimentado com efluente de reator anaeróbio horizontal de leito fixo. Tese (Doutorado) - Escola de Engenharia de São Carlos, Universidade de São Paulo, São Carlos.

Jimenez, B., Noyola, A., Capdeville, B., Roustan, M., Faup, G. (1988) Dextran blue colorant as a reliable tracer in submerged filters. Water Research 22,1253-1257.

Levenspiel, O. (2000) Engenharia das reações químicas. 3ª Edição. Editora Edgard Blucher Ltda.

Lima, C.A.A. (2001) Tratamento de esgoto sanitário em reator anaeróbio horizontal de leito fixo (RAHLF) - Escala Piloto. Tese (Doutorado) - Escola de Engenharia de São Carlos, Universidade de São Paulo, São Carlos.

Marchetto, M. (2001) Remoção de nutrientes do efluente de reator anaeróbio utilizando reatores microaeróbio e com aeração intermitente seguidos por flotação por ar dissolvido. 238 p. Tese (Doutorado) - Escola de Engenharia de São Carlos, Universidade de São Paulo, São Carlos, 2001.

Mendonça, L.C. (2002) Microbiologia de sistema de lodos ativados com pós tratamento de efluente de reator anaeróbio de leito expandido. 219 p. Tese (doutorado) - Escola de Engenharia de São Carlos, Universidade de São Paulo, São Carlos.

Moraes, B.S. (2009) Utilização de sulfeto com doador de elétrons para a desnitrificação autotrófica aplicada ao tratamento de esgotos sanitário. Dissertação (mestrado) - Escola de Engenharia de São Carlos, Universidade de São Paulo, São Carlos.

Nation, J.L. (1983) A new method using hexamethyldilazane for preparation of soft issues for scanning electron microscopy. Satin technology. 58,347-351.

Pantoja Filho, J.L.R.; Sader, L.T.; Damianovic, M.H.R.Z.; Foresti, E.; Silva, E.L. (2010) Performance evaluation of packing materials in the removal of hydrogen sulphide in gas-phase biofilters: Polyurethane foam, sugarcane bagasse, and coconut fibre. Chemical Engineering Journal. $158,441-450$

Pessoa, E.P.; Jordão, C.A. (2005) Tratamento de esgotos domésticos. $4^{\mathrm{a}}$ Edição. Editora da ABES: Associação Brasileira de Engenharia Sanitária e Ambiental. 932 p.

Pradyot Patnaik. (2002) Handbook of Inorganic Chemicals. McGraw-Hill. 1086 p. 
Ribeiro, R.; Varesche, M.B.A.; Foresti, E.; Zaiat, M. (2005). Influence of the carbon source on the anaerobic biomass adhesion on poliurethane foam matrices. Journal of Environmental Management. 74(2), 187-194

Schimdt, ET.; Belser, L.W. (1984) Nitrifying bacteria, in: "Methods of soil analysis Chemical and microbiological properties”. Number 9, part 2, 2a Edição, p.1027-1042. USA

Tiedje, J.M. (1982) Denitrification ecological niches, competition and survival. Antoine van Leenwenhoek Journal of Microbiology, p 568-583

Van Haandel, A.; Lettinga, G. (1994) Tratamento anaeróbio de esgoto-um manual para regiões de clima quente. Campina Grande-PB.

Victoria, J.A.R (2006) Filtro biológico aeróbio-anóxico para remoção de nitrogênio de reatores $U A S B$. Tese (doutorado) - Escola de Engenharia de São Carlos, Universidade de São Paulo, São Carlos.

Vieira, L.G.T. (2000) Desenvolvimento de sistema misto aeróbio-anaeróbio d eleito fixo para remoção de nitrogênio de esgoto sanitário pré-tratado em reator anaeróbio. Tese (doutorado) Escola de Engenharia de São Carlos, Universidade de São Paulo, São Carlos.

Zaiat, M. Desenvolvimento de reator anaeróbio horizontal de leito fixo para tratamento de águas residuárias. Tese (Doutorado) - Escola de Engenharia de São Carlos, Universidade de São Paulo, São Carlos. 


\section{Resultados e discussão}

"Às vezes dizem que cientistas não são românticos, que sua paixão pelo conhecimento rouba a beleza e o mistério do mundo. Mas não é delicioso entender como o mundo de fato funciona? - Não é delicioso saber que aquela luz branca é feita de cores, que a cor é o modo como percebemos as ondas de luz, que aquele ar transparente reflete a luz, que assim fazendo-o, diferencia as demais ondas, e que o céu é azul pelo mesmo motivo que o crepúsculo é vermelho? O romance do pôr-do-sol não vai ser estragado se você souber um pouco sobre ele."

Carl Sagan 


\subsection{CARACTERIZAÇÃO HIDRODINÂMICA}

\subsubsection{CURVAS-RESPOSTA}

Conforme observado por outros autores (Jimenez et al., 1988; De Nardi et al., 1999; Lima, 2001), o uso de diferentes traçadores resultou em diferentes curvas-resposta nos experimentos realizados sob as mesmas condições operacionais. Tais diferenças, em outras configurações de reatores, podem ser atribuídas às diferentes características dos traçadores utilizados nos experimentos.

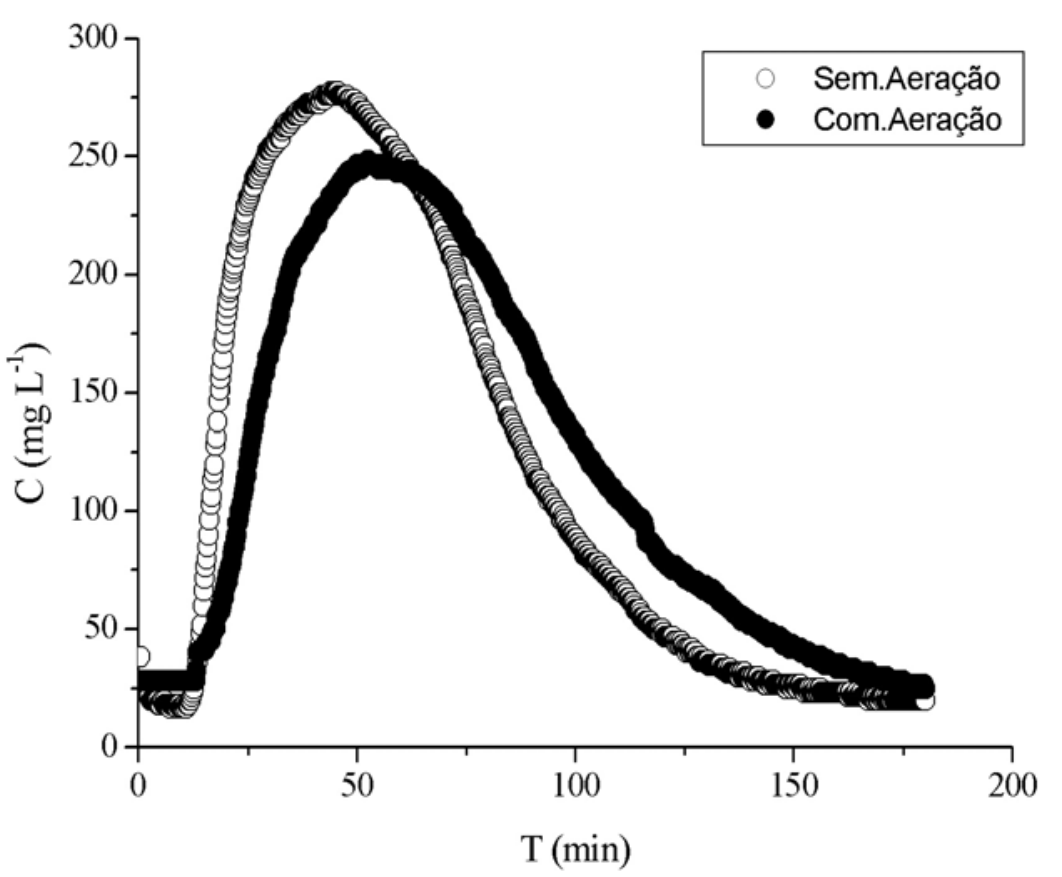

Figura 5: Curvas-resposta obtidas tendo o cloreto de sódio como traçador $(\theta \mathrm{h} \sim 1 \mathrm{~h})$. 


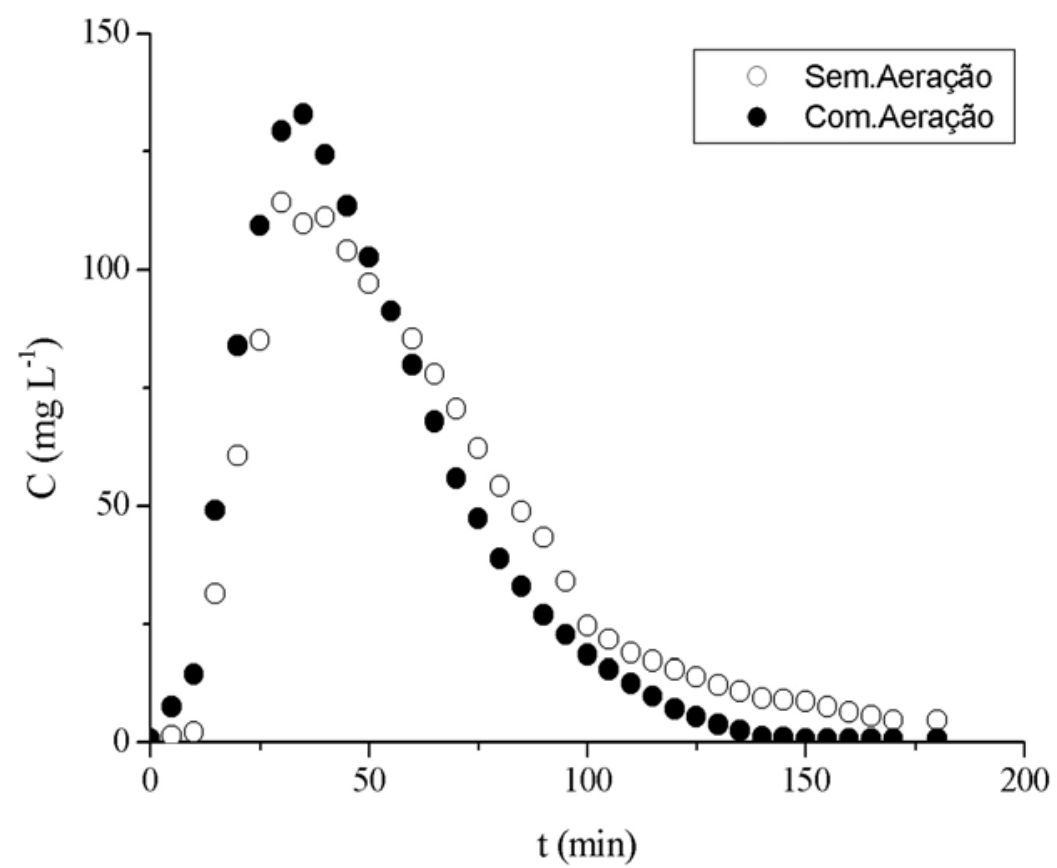

Figura 6: Curvas-resposta obtidas tendo a eosina $\mathrm{Y}$ como traçador $(\theta \mathrm{h} \sim 1 \mathrm{~h})$

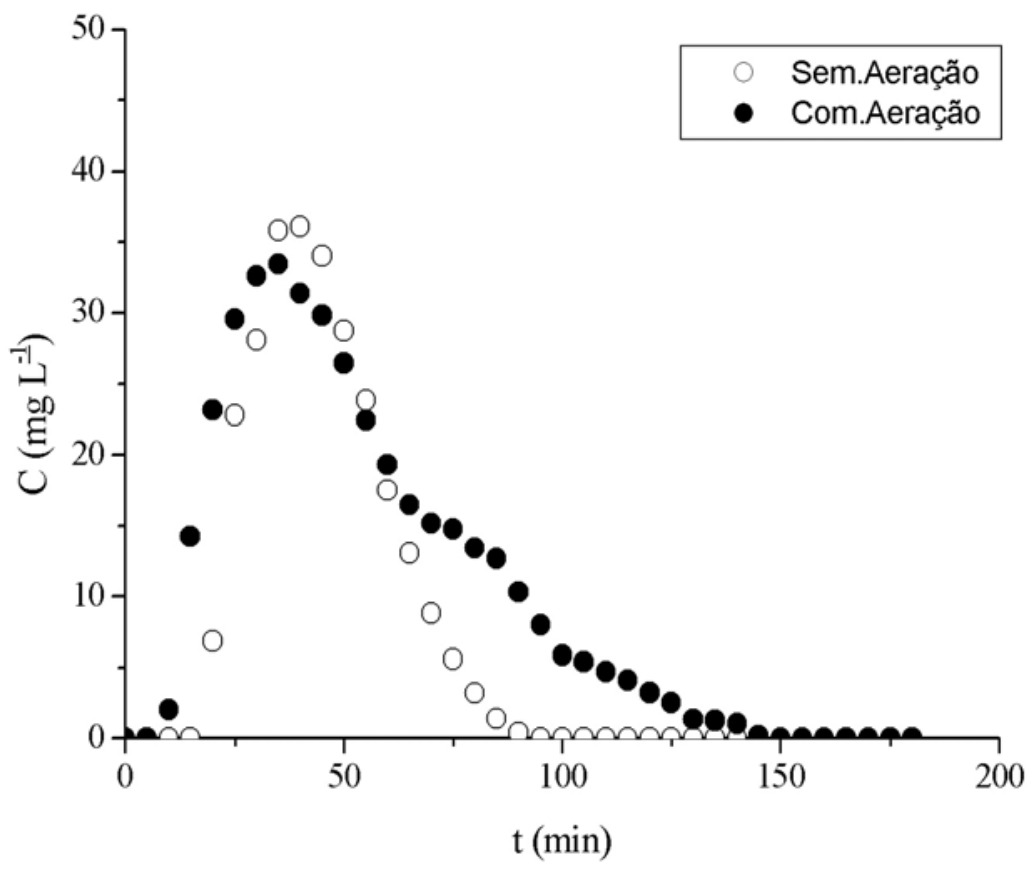

Figura 7: Curvas-resposta obtidas tendo o azul de bromofenol como traçador $(\theta \mathrm{h} \sim 1 \mathrm{~h})$ 


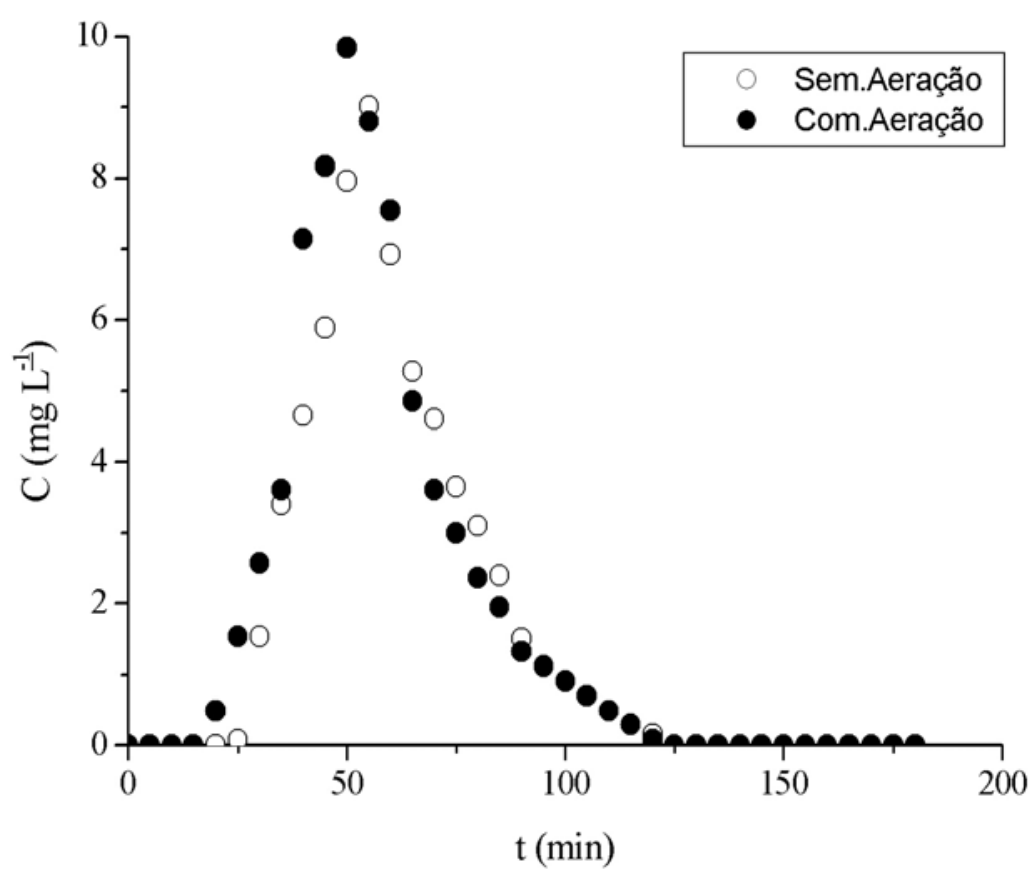

Figura 8: Curvas-resposta obtidas tendo a dextrana azul como traçador $(\theta \mathrm{h} \sim 1 \mathrm{~h})$

\subsubsection{O EFEITO DE CAUDA}

O efeito de cauda pode ser visualmente observado nos gráficos obtidos a partir dos ensaios realizados com todos os traçadores avaliados e em todas as condições experimentais.

As curvas com efeito de cauda mais acentuado refletem o decaimento vagaroso da concentração detectada no ponto de saída do reator (Jimenez et al., 1988). A injeção de gás intensificou este efeito conforme apresentado na Tabela 9. 
Tabela 9: Resultados obtidos para as condições experimentais no ensaio hidrodinâmico

\begin{tabular}{cccccccc}
\hline Injeção de ar & Traçador & $\begin{array}{c}\overline{\theta h} \\
(\mathrm{~min})\end{array}$ & $\begin{array}{c}\mathrm{tP} \\
(\sim \mathrm{min})\end{array}$ & $\mathrm{tP} / \overline{\theta h}$ & $\begin{array}{c}\mathrm{M}_{\text {inj }} \\
(\mathrm{mg})\end{array}$ & $\begin{array}{c}\mathrm{M}_{\text {rec }} \\
(\mathrm{mg})\end{array}$ & $\mathrm{M}_{\text {rec }} / \mathrm{M}_{\text {inj }}$ \\
\hline Sim & Cloreto de & 63,7 & 54 & 0,84 & 1250 & 815 & 0,65 \\
Não & Sódio & 74,3 & 44 & 0,59 & 1250 & 834 & 0,67 \\
\hline Sim & Eosina Y & 45,6 & 35 & 0,76 & 250 & 192 & 0,64 \\
Não & 49,9 & 30 & 0,60 & 250 & 233 & 0,81 \\
\hline Sim & Azul de & 44,6 & 35 & 0,78 & 100 & 52 & 0,52 \\
Não & bromofenol & 52,8 & 40 & 0,75 & 100 & 74 & 0,74 \\
\hline Sim & Dextrana & 55,2 & 40 & 0,72 & 15 & 12 & 0,82 \\
Não & azul & 51,4 & 45 & 0,87 & 15 & 14 & 0,91 \\
\hline
\end{tabular}

O uso de diferentes traçadores resultou em diferentes curvas-resposta, embora os ensaios tivessem sido realizados sob as mesmas condições operacionais. Isto deve-se às características intrísecas de cada traçador.

De acordo com Rebhun e Argaman (1965), a razão tP/ $\overline{\theta h}$ indica a tendência de comportamento de fluxo pistonado quando é próxima de 1 . Um resultado de 0,87 foi obtido nos testes realizados com a dextrana azul sob condições de não injeção de ar, enquanto para o cloreto de sódio, a razão tP/ $\overline{\theta h}$ foi a mais baixa entre todos os traçadores, 0,59 , indicando um grau maior de mistura.

O efeito de cauda é explicado pelo fato de que, antes da introdução do traçador no reator, os poros do material suporte estão preenchidos somente com água, então a concentração de traçador nos poros do material suporte é igual a zero. À medida que o traçador na forma de pulso escoa ao longo do leito, a concentração de traçador no fluxo aumenta e um gradiente é formado.

A difusão ocorre a partir do fluxo principal em direção aos poros do material suporte. Portanto, quando o pulso passa, a concentração do traçador do fluxo principal tende a decrescer e eventualmente 
se torna menor do que a concentração dentro dos poros do material suporte, o que acarreta na inversão do gradiente, e a difusão ocorre na direção contrária (contra-difusão).

\subsubsection{TEMPO DE RESIDÊNCIA VERDADEIRO}

De acordo com a Tabela 9, pode ser observado que houve uma considerável variação no tempo de residência médio $(\overline{\theta h})$ obtido a partir das curvas de distribuição do tempo de residência (DTR), conforme pode ser observado,por exemplo, no ensaio com azul de bromofenol com injeção de ar ( $t_{R}$ de $44.6 \mathrm{~min})$ ou no ensaio com cloreto de sódio sem injeção de $\operatorname{ar}(\overline{\theta h}=74.3 \mathrm{~min})$.

Considerando os ensaios nos quais o mesmo traçador foi utilizado, mas sob diferentes condições de injeção de ar (com ou sem), pode-se concluir que a presença de bolhas afetou os valores de $t_{R}$, uma vez que, nos testes realizados com injeção de ar, os valores de $t_{R}$ foram menores para todos os traçadores, exceto para a Dextrana Azul. Isto pode ser explicado pelo fato de as bolhas preencherem espaços dentro do reator (gás “hold-up”), o que resulta na diminuição do seu volume útil, resultando em valor de $\theta$ h inferior.

Com relação ao tempo de pico, a injeção de gás resultou na antecipação dos picos das curvas, o que pode indicar a presença de curtos-circuitos e, consequentemente, de zonas mortas. $\mathrm{O}$ efeito foi mais intenso nos ensaios realizados com a eosina $\mathrm{Y}$ ( $\mathrm{tP} \sim 30 \mathrm{~min}$, sem injeção de ar). Entretanto, foi menos intenso nos testes realizados com cloreto de sódio e dextrana azul (tP $\sim 54$ e 45 min, respectivamente), uma vez que curvas mais delgadas podem ser notadas e o tempo verdadeiro está muito próximo do pico da curva.

\subsubsection{RECUPERAÇÃO DOS TRAÇADORES}

Com relação à recuperação das substâncias após os testes, a eosina $\mathrm{Y}$, o azul de bromofenol e o cloreto de sódio apresentaram 64\%, 52\% e 65\%, respectivamente, nos ensaios realizados com injeção 
de ar. Os resultados para a eosina $\mathrm{Y}$ estiveram muito próximos daqueles apresentados por Jimenez et al. (1988) em seus estudos com traçadores sob condições abióticas, quando 60-65\% da eosina Y foi recuperada em todos os testes.

É importante também notar que, para todos os traçadores avaliados, a relação $\mathrm{M}_{\mathrm{rec}} / \mathrm{M}_{\mathrm{inj}}$ foi maior quando os testes foram realizados sem injeção de ar. Apenas para propósito de comparação, o percentual de recuperação para o azul de bromofenol foi maior no ensaio realizado por Jimenez et al. (1988) sob condições de não injeção de ar, com percentual de recuperação de 74\%.

Por outro lado, nos ensaios realizados com a dextrana azul, percentuais de recuperação oscilando entre $82-90 \%$ da massa injetada foram observados em todos os testes, o que está de acordo com a literatura. Este melhor desempenho em termos de recuperação da massa injetada nos ensaios com dextrana azul pode ter ocorrido devido à sua baixa capacidade de absorção/adsorção previamente mostrada por outros autores (Jimenez et al., 1988; De Nardi et al., 1999).

Também, o efeito de difusão deveria ser considerado, uma vez que foi verificado por Jimenez et al. (1988), De Nardi et al. (1999) no estudo hidrodinâmico de leitos porosos, por Stevens et al. (1986) em um reator fluidizado e por Carvalho et al. (2008) em um reator UASB.

\subsubsection{MODELOS UNIPARAMÉTRICOS}

A partir da construção das curvas de distribuição do tempo de residência e a tentativa de ajuste aos modelos uniparamétricos, verificou-se que a maioria dos traçadores avaliados não apresentou resultados satisfatórios.

A dextrana azul foi a única exceção, porque foi possível obter um bom ajuste ao modelo de número de tanques de mistura perfeita em série (N-CSTR) e ao modelo de dispersão axial (MDAbaixa dispersão), conforme pode se observado na Tabela 9 e nos gráficos da Figura 9. 
Tabela 10: Coeficiente de correlação obtidos a partir do ajuste dos modelos teóricos às curves experimentais obtidos para cada experimento no RAALF, considerando um tempo de detenção hidráulica de 1 hora.

\begin{tabular}{ccccc}
\hline \multirow{2}{*}{ Traçador } & Injeção de ar & \multicolumn{3}{c}{ Coeficiente de correlação } \\
\cline { 3 - 5 } & Não & 0,325 & 0,320 & N-CSTR em \\
série*** & Baixa dispersão* & Alta dispersão** \\
\hline \multirow{2}{*}{ Cloreto de sódio } & Sim & 0,400 & 0,395 & 0,315 \\
& Não & 0,978 & 0,971 & 0,385 \\
\hline \multirow{2}{*}{ Eosina Y } & Sim & 0,482 & 0,445 & 0,971 \\
\hline Azul de & Não & 0,695 & 0,686 & 0,439 \\
bromofenol & Sim & 0,768 & 0,760 & 0,684 \\
\hline \multirow{2}{*}{ Dextrana azul } & Não & 0,956 & 0,976 & 0,757 \\
\hline & Sim & 0,978 & 0,988 & 0,878 \\
\hline
\end{tabular}

* Equação 25; ** Equação 26; ***Equação 27

As diferentes características dos traçadores afetaram os parâmetros dos modelos uniparamétricos. Os resultados com o cloreto de sódio mostraram a mais baixa correlação entre os dados experimentais e os modelos. De maneira geral, constatou-se, conforme já observado por outros pesquisadores (Jimenez et al., 1988; De Nardi et al., 1999), que os traçadores utilizados, com exceção da dextrana azul, não são adequados para descrever corretamente o comportamento hidrodinâmico de reatores de leito fixo.

Baseando-se na Tabela 11, pode-se concluir que os parâmetros $\mathrm{N}$ e D/uL são claramente dependentes do traçador escolhido para a avaliação do fenômeno. Pode-se esperar que a presença de bolhas de ar exerça grande influência nos valores dos parâmetros que descrevem o fenômeno. No entanto, constatou-se que a intensidade dessa influência é também dependente do tipo de traçador. 
Tabela 11: Parâmetros dos modelos uniparamétricos obtidos param cada experimento no RAALF, considerando $\theta$ h de 1 hora.

\begin{tabular}{ccccc}
\hline Traçador & Injeção de ar & D/uL (alto) & D/uL (baixo) & $\mathrm{N}$ \\
\hline \multirow{2}{*}{ Cloreto de sódio } & Não & 0,151 & 0,101 & 3 \\
& Sim & 0,125 & 0,130 & 3 \\
\hline \multirow{2}{*}{ Eosina Y } & Não & 0,151 & 0,130 & 3 \\
& Sim & 0,148 & 0,129 & 3 \\
\hline \multirow{2}{*}{ Azul de bromofenol } & Não & 0,051 & 0,060 & 10 \\
& Sim & 0,082 & 0,100 & 6 \\
\hline \multirow{2}{*}{ Dextrana azul } & Não & 0,021 & 0,010 & 10 \\
& Sim & 0,033 & 0,018 & 8 \\
\hline
\end{tabular}

As diferentes condições avaliadas foram responsáveis pelas mudanças nas formas das curvas em todos os testes. A discrepância mais notada ocorreu nos testes realizados com azul de bromofenol, mas também foi observada para todos os traçadores, uma vez que os parâmetros dos modelos matemáticos mudaram.

Por exemplo, considerando-se os dados obtidos nos ensaios sem injeção de ar, pode ser observado que a dextrana azul indica um grau mais baixo de mistura no reator $(\mathrm{N}=10)$, enquanto um grau de mistura mais alto é predito quando o traçador é a eosina $\mathrm{Y}$ e o cloreto de sódio $(\mathrm{N}=3)$.

Ademais, a injeção de ar modificou suavemente os resultados dos parâmetros dos modelos para os testes com o mesmo traçador indicando que a presença de bolhas causou um aumento no grau de mistura dentro do reator, especialmente para os ensaios realizados com o azul de bromofenol e a dextrana azul, com $\mathrm{N}$ variando de 10 a 6 para o azul de bromofenol e de 10 a 8 para a dextrana azul, e com $\mathrm{D} / \mathrm{uL}_{\text {baixo }}$ variando de 0,051 a 0,082 para o azul de bromofenol e de 0,021 a 0,033 para a dextrana azul. 


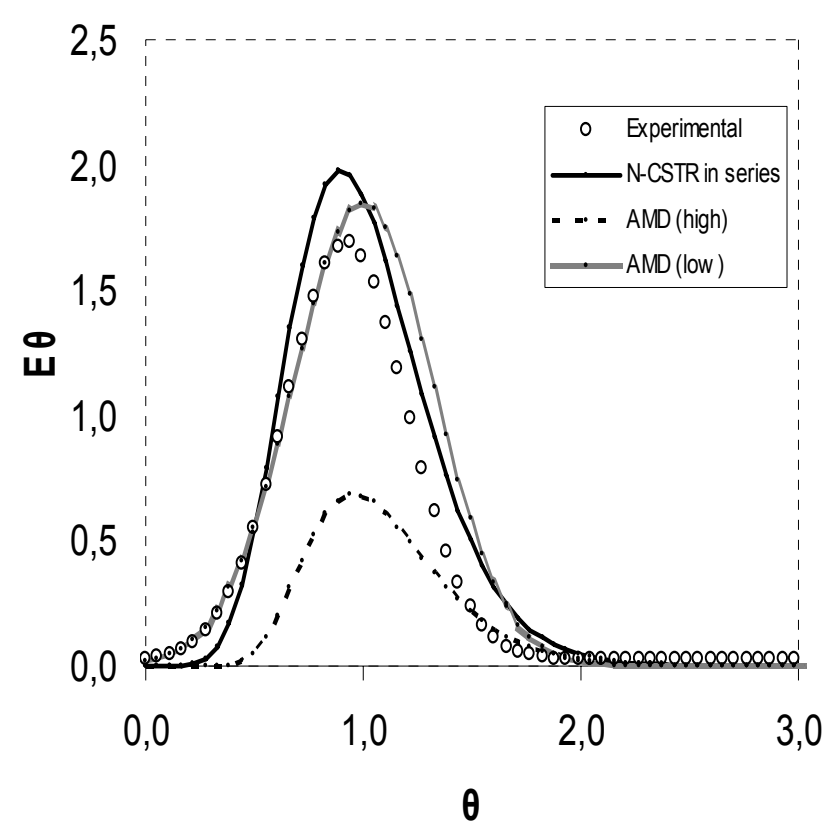

Ensaios com injeção de ar

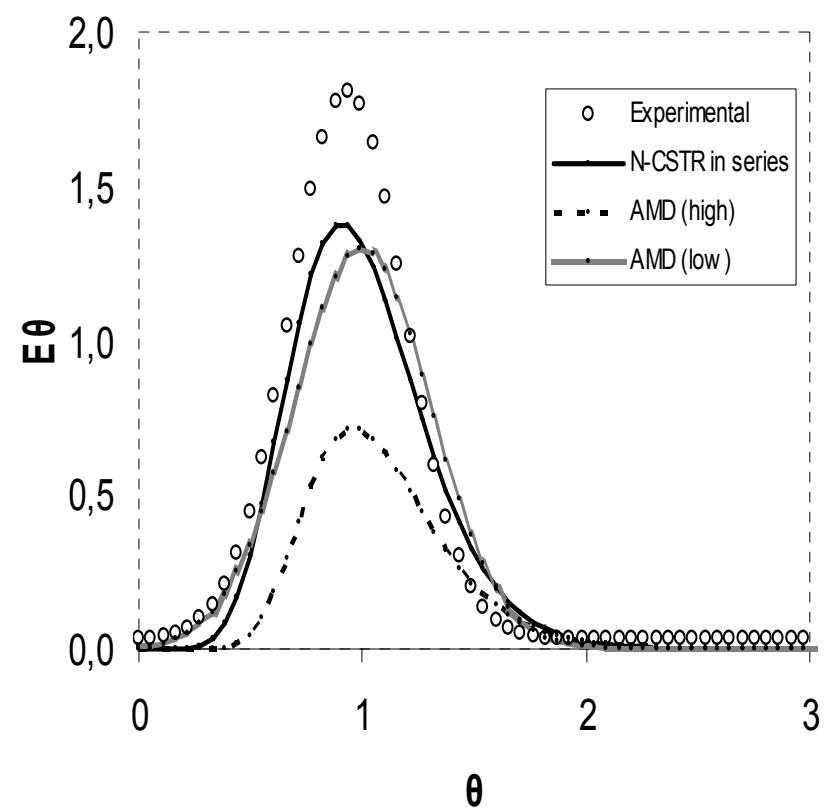

Ensaios sem injeção de ar

Figura 9: Curvas de distribuição do tempo de residência obtidas a partir dos ensaios realizados com dextrana azul e modelos teóricos N-CSTR e MDA (alta e baixa)

$$
(\theta \mathrm{h} \sim 1 \mathrm{~h})
$$

Levenspiel (2000) recomenda que o modelo MDA deveria se tornar questionável se D/uL $>1$. Todavia, mesmo quando $\mathrm{D} / \mathrm{uL}=0,151$ (cloreto de sódio), o modelo não se ajustou adequadamente aos dados experimentais sob as condições testadas. Domingues e Nour (2005) avaliaram a utilização de 
cloreto de sódio em um sistema combinado de tratamento de esgoto sanitário composto de um filtro anaeróbio seguido por um biofiltro aerado submerso e observaram que, mesmo para valores de $\mathrm{D} / \mathrm{uL}$ entre 0,043 e 0,060 , não foi possível obter um bom ajuste aos modelos uniparamétricos.

\subsubsection{AVALIAÇÃO COM DEXTRANA AZUL}

Provavelmente devido ao seu alto peso molecular (2.000.000), a dextrana azul foi o traçador que apresentou o melhor ajuste aos modelos uniparamétricos (N-CSTR em série e o modelo MDA baixa dispersão $-\mathrm{D} / \mu \mathrm{L}_{\text {baixo }} \sim 0.01$ ) na primeira parte deste estudo. Por esta razão, a dextrana azul foi avaliada para diferentes $\theta$ h, de 3 e 5 horas, a fim de se obter o padrão de escoamento para diferentes velocidades descendentes e a fim de se estudar o comportamento do reator para os $\theta$ h aplicados durante a etapa de monitoramento do reator.

Como a velocidade descendente diminuiu com o aumento do $\theta \mathrm{h}$, o grau de mistura do reator também diminuiu, conforme apresentado pelos paramétricos dos modelos uniparamétricos. Considerando o modelo N-CSTR, o paramêtro N mudou ligeiramente de 10 para 14 e de 11 para 12 para os ensaios com e sem injeção de ar, respectivamente. Este comportamento também foi observado por De Nardi et al. (1999) em reator horizontal de leito fixo, em testes com a dextrana azul. Todavia, a aplicação da análise estatística ANOVA permitiu verificar que não houve diferença estatística significante no padrão de escoamento para os $\theta \mathrm{h}$ aplicados. 
Tabela 12: Parâmetros dos modelos matemáticos obtidos para cada experimento no RAALF, considerando $\theta$ h de 1,3 e 5 horas para a dextrana azul.

\begin{tabular}{ccccc}
\hline$\theta$ h & Injeção de ar & $\begin{array}{c}\mathrm{D} / \mathrm{uL} \\
\text { (alto) }\end{array}$ & $\begin{array}{c}\mathrm{D} / \mathrm{uL} \\
\text { (baixo) }\end{array}$ & $\mathrm{N}$ \\
\hline \multirow{2}{*}{1} & Não & 0,021 & 0,010 & 10 \\
& Sim & 0,023 & 0,018 & 8 \\
\hline \multirow{2}{*}{3} & Não & 0,020 & 0,010 & 13 \\
& Sim & 0,022 & 0,012 & 11 \\
\hline \multirow{2}{*}{5} & Não & 0,017 & 0,009 & 14 \\
& Sim & 0,020 & 0,010 & 12 \\
\hline
\end{tabular}

Finalmente, como detectado na primeira parte do estudo hidrodinâmico, as bolhas de ar influenciaram os parâmetros (grau de mistura maior com injeção de ar). Porém, o efeito sobre os parâmetros dos modelos pode ser considerado pouco significativo, uma vez que os valores obtidos permitem admitir que o escoamento pistonado descreve o comportamento do reator de maneira apropriada.

A informação do comportamento hidrodinâmico do RAALF é importante pois se o escoamento no seu interior é tendendo ao pistonado, significa que os reagentes são continuamente consumidos à medida que avançam no reator ao longo de seu comprimento. O pressuposto fundamental é que, como um pistão fluindo através de um reator de fluxo pistonado, o fluido é perfeitamente misturado na direção radial, mas não na direção axial. Em outras palavras, esse comportamento do fluido no interior do RAALF é de extrema importância para o estabelecimento das reações de interesse que, em tese, devem ocorrer de maneira seqüencial para possibilitar o sucesso do reator. 


\subsection{MONITORAMENTO DO DESEMPENHO DO RAALF}

O monitoramento do desempenho do reator na remoção de nitrogênio foi dividido em três condições, sendo:

- a condição 1 foi definida como aquela na qual o reator atingiu e manteve o equilíbrio dinâmico aparente com relação à oxidação do nitrogênio amoniacal e da matéria orgânica carbonácea na câmara aeróbia;

- durante a condição 2 (sub-condições 2.1, 2.2 e 2.3), foram avaliados três diferentes tempos de detenção hidráulica $(\theta h)(7,5 ; 5$ e 2,5 horas) com concentrações dos doadores de elétrons presentes no biogás sintético da ordem de $\mathrm{H}_{2} \mathrm{~S}=50 \mathrm{gm}^{3}$ e $\mathrm{CH}_{4}=380 \mathrm{gm}^{-3}$;

- e durante a condição 3, foi utilizado o $\theta$ h de 5 horas durante a etapa 2 com redução na concentração de sulfeto de hidrogênio presente no biogás (de 50 para 0,5 gm³ $^{3}$ e manutenção da concentração de $\mathrm{CH}_{4} \mathrm{em} 380 \mathrm{gm}^{3}$.

Desta forma buscou-se avaliar o comportamento do reator principalmente quantos às características hidráulicas (variação da velocidade descensional) e bioquímicas (disponibilidade de doadores de elétrons para a desnitrificação). 


\subsubsection{ANÁLISE DA CONDIÇÃO 1}

A operação nesta etapa deu-se sob um $\theta$ h teórico, considerando o volume útil do reator, de 3 horas na câmara aeróbia e de 4,5 horas na câmara anóxica, totalizando um $\theta$ h útil total de 7,5 horas. A vazão aplicada para possibilitar o $\theta$ h de estudo foi de $12 \mathrm{~mL} \mathrm{~min}^{-1}$.

\subsubsection{Dinâmica das formas nitrogenadas}

Com base nos gráficos da Figura 10 e Figura 11, observa-se que a estabilização da nitrificação foi obtida dentro de um tempo relativamente curto, de aproximadamente 15 dias, indicando que a inoculação com lodos ativados foi satisfatória no sentido de prover biomassa relativamente adaptada para a realização do processo de nitrificação.

Garbossa (2006), operando um reator radial de leito fixo aplicado ao pós-tratamento de esgoto sanitário, também verificou comportamento similar no tocante à partida do seu reator para compostos nitrogenados, preenchido com espumas de poliuretano e inoculado com lodos ativados. Talvez, essa estratégia (lodo+material suporte adotados), associada às características dos reatores de leito fixo, seja de fato eficaz para prover um ambiente mais favorável ao crescimento dos microrganismos nitrificantes, fazendo com que a partida seja relativamente rápida. 


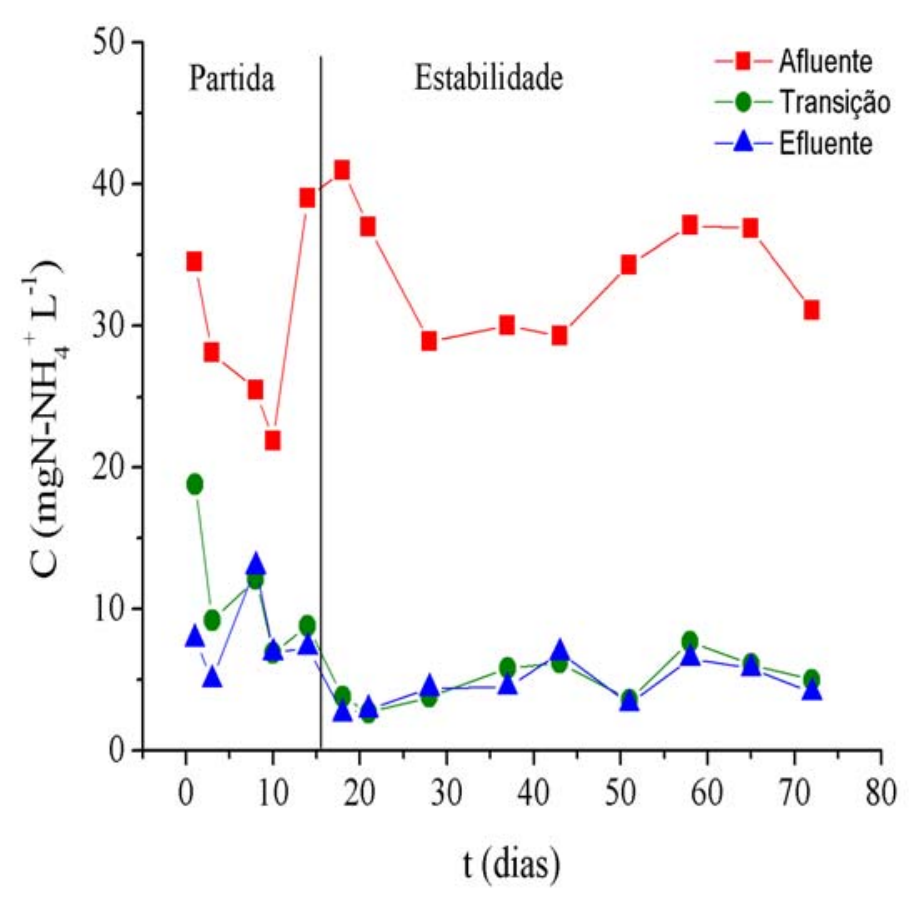

Figura 10: Dinâmica do nitrogênio amoniacal (Condição 1)

Depois de atingido o equilíbrio dinâmico aparente no processo de nitrificação, a concentração de nitrito detectada foi desprezível. Portanto, o nitrato foi o produto principal detectado a partir da oxidação do nitrogênio amoniacal, conforme apresentado na Figura 11.

A concentração de nitrato afluente ao reator também foi desprezível durante todo o período operacional desta condição, pois o reator de montante era um reator anaeróbio do tipo UASB, e sabese que, em sistemas como esse, a conversão mais importante de nitrogênio é a amonificação (conversão do nitrogênio orgânico a nitrogênio amoniacal), além da assimilação de uma pequena porção do nitrogênio amoniacal para produção de lodo. 


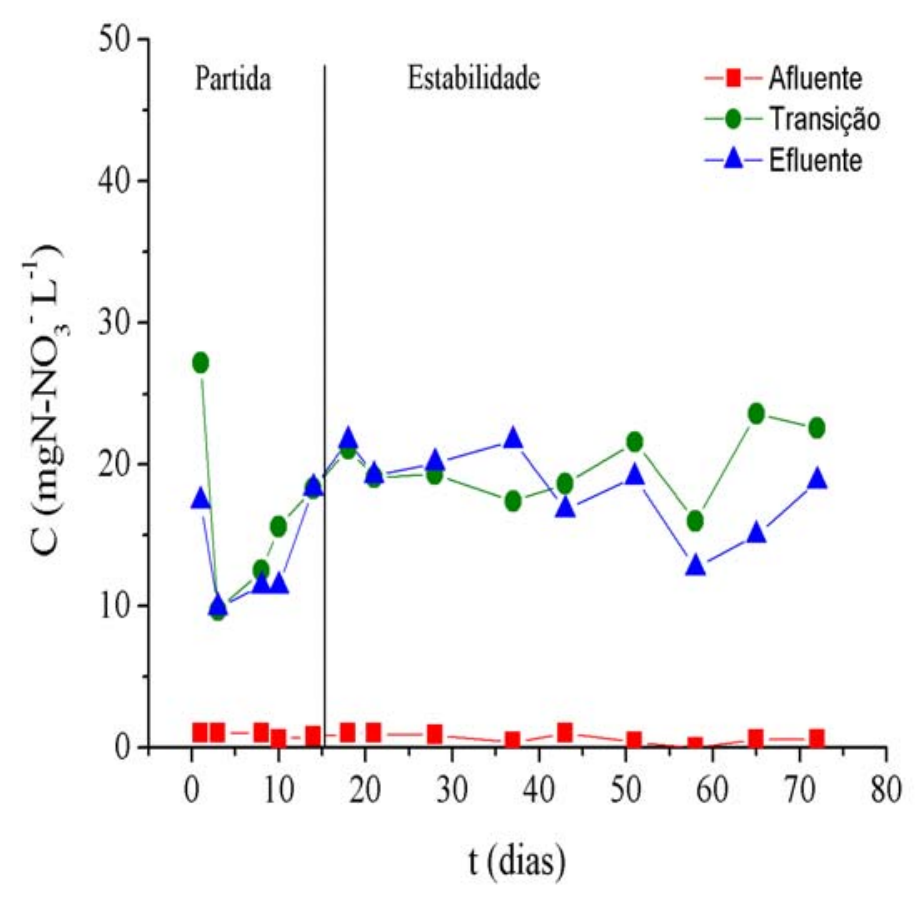

Figura 11: Dinâmica do nitrato (Condição 1)

A câmara aeróbia apresentou boa estabilidade operacional nesta etapa, com eficiência média de remoção de nitrogênio amoniacal de $82,3 \%$, para a concentração média afluente de $33,1 \pm 1,3 \mathrm{mg} \mathrm{L}^{-1}$ e concentração média efluente de $5,1 \pm 0,6 \mathrm{mg} \mathrm{L}^{-1}$. As concentrações de nitrato afluente e na fase de transição foram de $0,7 \pm 0,1$ e $18,8 \pm 1,2 \mathrm{mg} \mathrm{L}^{-1}$, respectivamente.

Importante ressaltar que a inoculação e o início da operação dos compartimentos aeróbio e desnitrificante foram realizados no mesmo período. $\mathrm{O}$ intuito deste procedimento foi procurar favorecer o crescimento de biomassa possivelmente precursora de microrganismos desnitrificantes para a rápida partida do sistema na etapa de introdução de biogás (condição 2).

\subsubsection{Dinâmica de remoção da matéria orgânica carbonácea}

Com relação à remoção de matéria orgânica carbonácea no reator, esta ocorreu de forma definitiva na câmara aeróbia, com equilíbrio dinâmico verificado no início da terceira semana de operação (por volta do $15^{\circ}$ dia), conforme pode ser verificado pelos valores de DQO apresentados no 
80

gráfico da Figura 12. Cabe observar, também, que o reator mostrou-se eficiente no tocante à equalização dos picos de carga orgânica ao qual foi constantemente submetido, principalmente após o $30^{\circ}$ dia de operação.

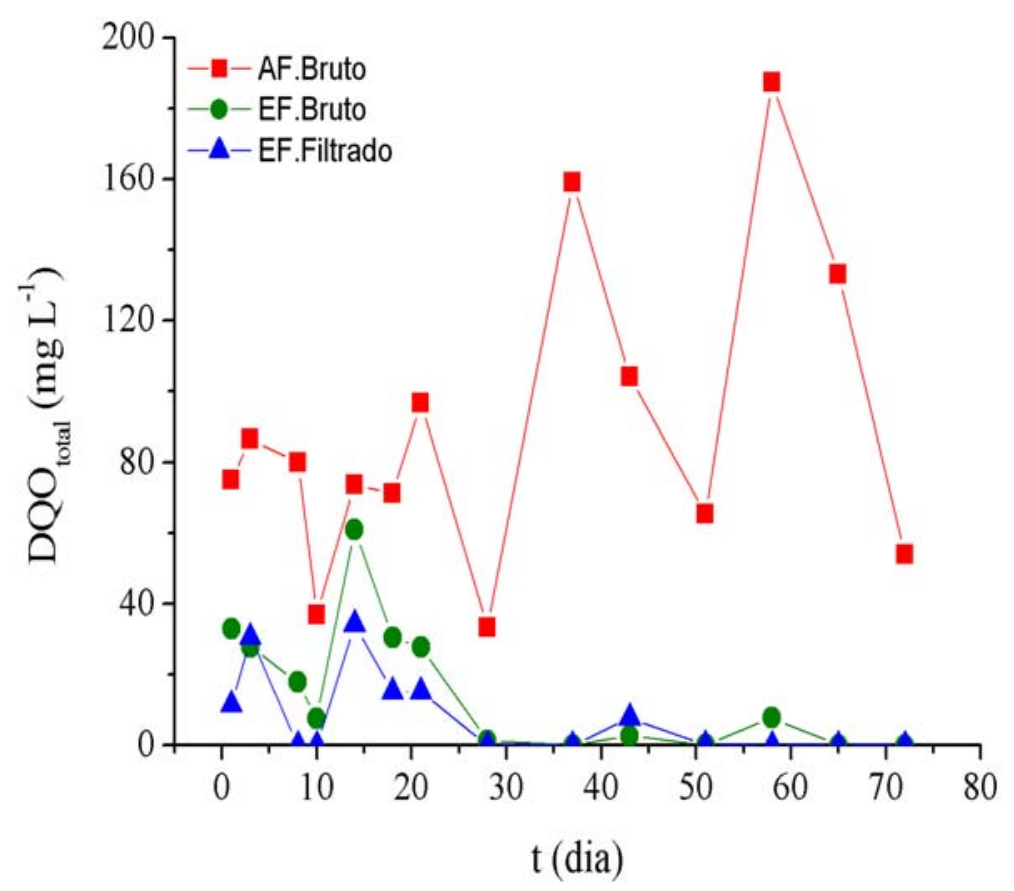

Figura 12: Dinâmica da DQO total $($ Condição 1)

Cabe ressaltar que o tempo necessário para que a biomassa heterotrófica pudesse se estabelecer no reator foi semelhante ao demandado pela biomassa autotrófica nitrificante. Esse fato pode ter ocorrido graças à presença de grande diversidade de microrganismos no lodo aeróbio utilizado para inoculação da câmara aeróbia (Seção Material e Métodos, Figura 4), que resultou em tempo semelhante demandado para a oxidação de compostos de interesse pelos dois grupos de microrganismos. 


\subsubsection{Perfis espaciais das espécies de nitrogênio e da matéria orgânica carbonácea}

Na Figura 13 e na Figura 14, estão apresentados os resultados dos perfis espaciais de comportamento da matéria orgânica carbonácea (como $\mathrm{DQO}_{\text {total }} \mathrm{e} \mathrm{DQO}_{\text {filtrada }}$ ) e das formas nitrogenadas (como nitrogênio amoniacal e nitrato), realizados no final da condição 1, a partir da tomada de amostras ao longo do comprimento longitudinal do reator.

Pode-se notar uma intensa atividade biológica, tanto em termos de conversão da matéria carbonácea, quanto do nitrogênio amoniacal, ocorrendo antes mesmo da primeira tomada de amostras $(\mathrm{L} / \mathrm{D} \sim 0,8)$.

Estes resultados mostram que, na primeira metade longitudinal da câmara aeróbia do reator, ocorreu a maior atividade dos microrganismos, com $69,6 \%$ e $86,6 \%$ de remoção de matéria carbonácea, medida em termos de $\mathrm{DQO}_{\text {total }}$ e $\mathrm{DQO}_{\text {filtrada }}$ respectivamente, e $67,2 \%$ de remoção de nitrogênio amoniacal. Sendo assim, a segunda metade da câmara aeróbia, compreendida entre L/D $\sim 0,8$ e LD 2,4 , teve função de "polimento", tanto para a conversão da matéria carbonácea, quanto da matéria nitrogenada.

A partir desses resultados, pode-se inferir que a competição entre o grupo de microrganismos heterotróficos, responsável pela conversão da matéria orgânica carbonácea, e o grupo de microrganismos autotróficos, responsável pela oxidação do nitrogênio amoniacal, não prejudicou, de maneira efetiva, os processos biológicos preponderantes na câmara aeróbia. 


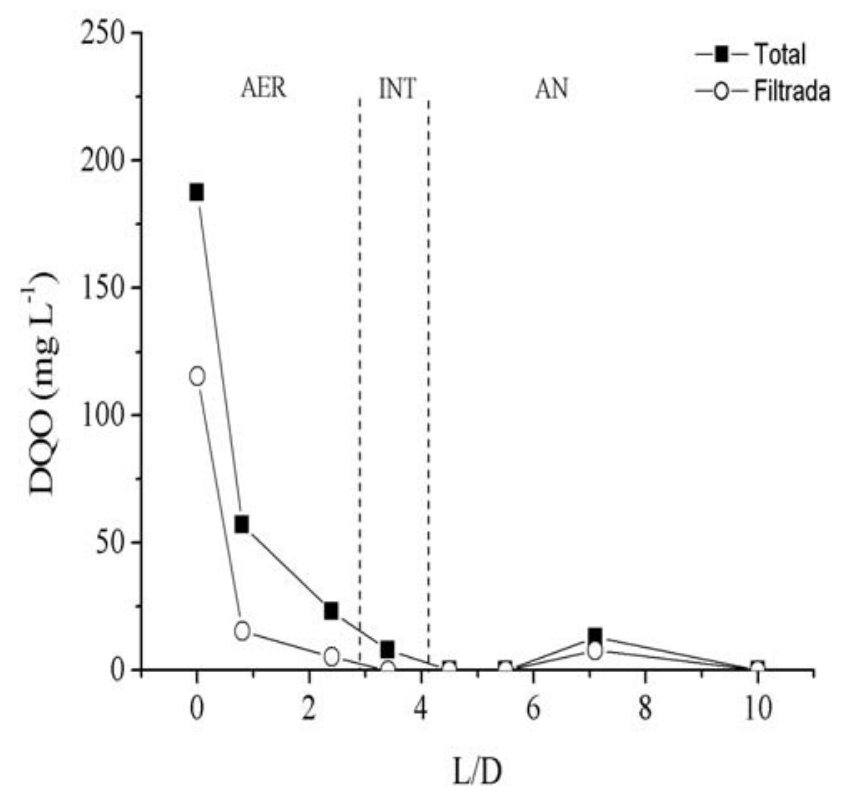

Figura 13: Perfil espacial de DQO (Condição 1)

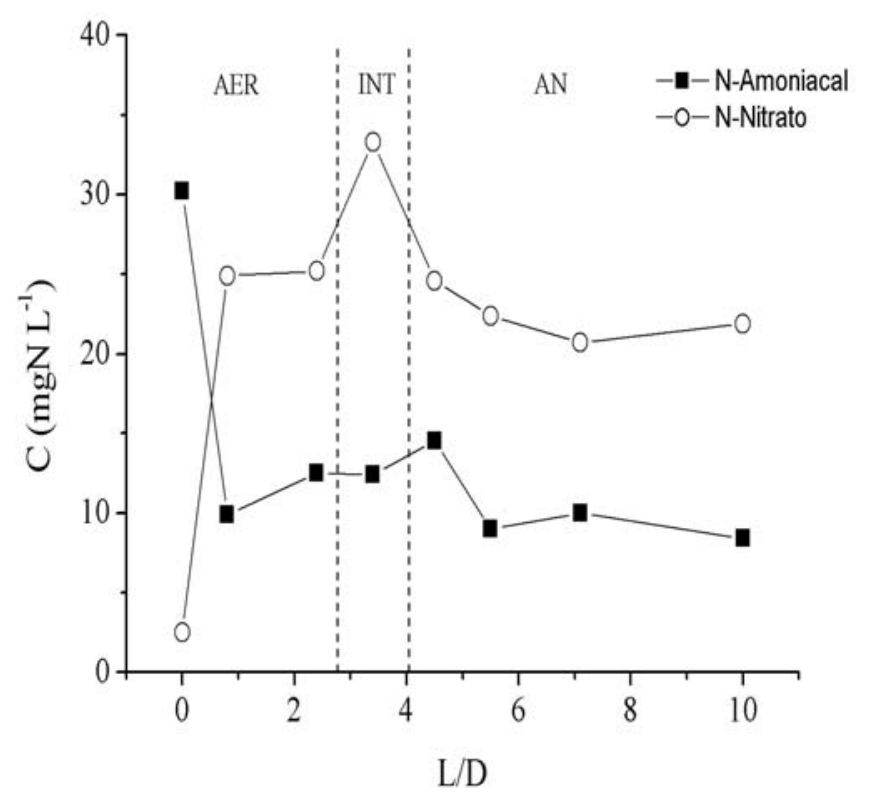

Figura 14: Perfil espacial de nitrogênio amoniacal e nitrato (Condição 1) 


\subsubsection{Oxigênio dissolvido e potencial redox}

Nesta condição a concentração de oxigênio dissolvido medida no meio líquido esteve acima das concentrações preconizadas pela literatura (EPA, 1975; Barney e Bliss, 1983; Kos, 1998; Van Handeel e Marais, 1999), tidas como satisfatórias para a ocorrência da nitrificação, com valor de $1,9 \pm 0,5 \mathrm{mg} \mathrm{L}^{-1}$ durante toda a condição. Os valores de potencial redox estiveram em torno de $+90 \mathrm{mV}$ indicando um sistema tipicamente aeróbio.

\subsubsection{Comportamento do pH e alcalinidade}

A alcalinidade e o pH são parâmetros importantes a serem monitorados durante a nitrificação, devido ao fato de o consumo de alcalinidade ser proporcional à conversão do nitrogênio amoniacal a nitrato.

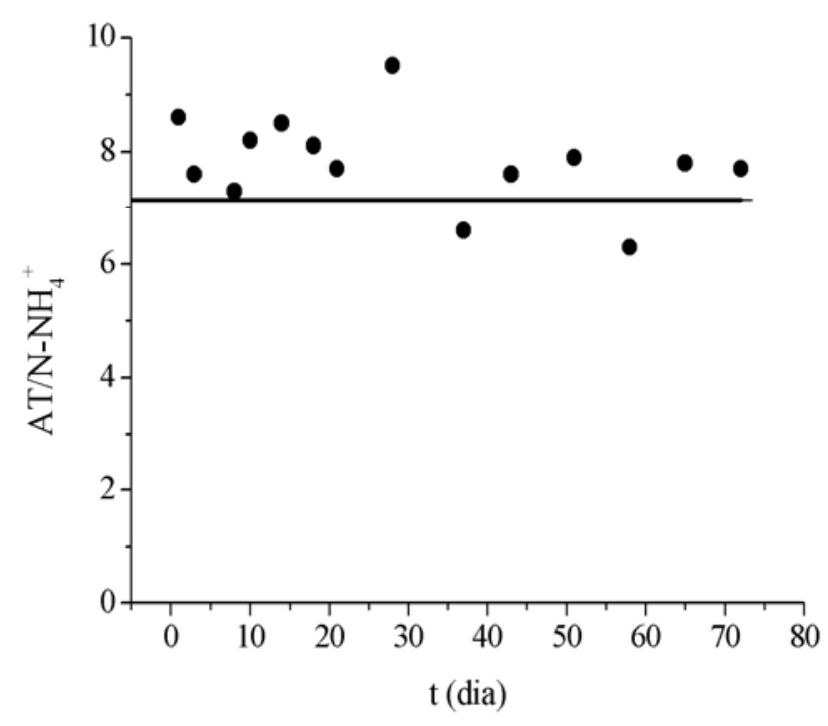

Figura 15: Valores da relação alcalinidade total/nitrogênio amoniacal (Condição 1)

No que se refere à alcalinidade disponível para a nitrificação, foi observado que a relação entre a alcalinidade total (medida como $\mathrm{CaCO}_{3}$ ) e a concentração de nitrogênio amoniacal deduzida estequiometricamente, considerada por Szwerinski et al.(1986) como necessária para que a nitrificação 
84

seja atingida $\left(\mathrm{AT} / \mathrm{N}-\mathrm{NH}_{4}{ }^{+}>7,14\right)$, esteve acima do valor teórico recomendado praticamente durante todo o período operacional nesta fase (Figura 15). Não foi necessária, portanto, a adição de alcalinizante externo nesta condição.

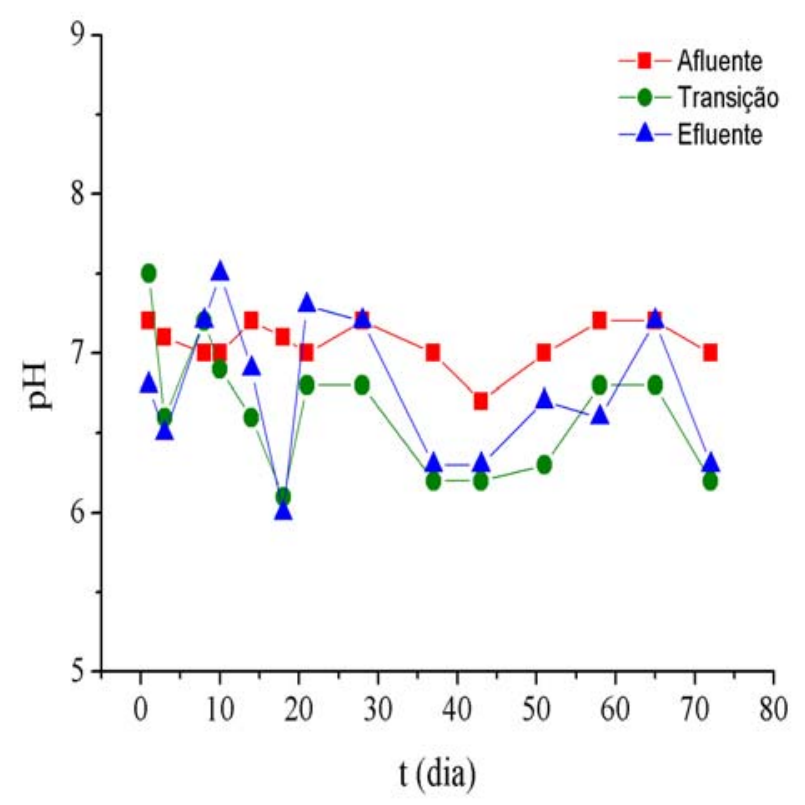

Figura 16: Comportamento do pH (Condição 1)

O comportamento do $\mathrm{pH}$, nesta condição, foi estável na câmara nitrificante (Figura 16). De modo geral, pode-se afirmar que a variação do $\mathrm{pH}$ na câmara nitrificante seguiu a variação da alcalinidade total. A alcalinidade afluente ao RAALF sofreu pouca variação, indicando a estabilidade do reator anaeróbio de montante.

\subsubsection{Dinâmica das formas de enxofre}

Com base na Figura 17, pode-se verificar que o aporte de sulfeto total dissolvido ao RAALF foi desprezível durante esta etapa. Isto pode ser devido, principalmente, à perda do sulfeto para a atmosfera na saída do UASB, uma vez que parte da vazão efluente ao UASB foi descartada em virtude de ser superior à vazão demandada pelo RAALF. Esta operação continua de descarte promoveu o contato do efluente com a atmosfera, resultando na oxidação de grande parte do sulfeto dissolvido. 
Ademais, pode-se notar, também, que o sulfato praticamente não foi convertido ao longo do reator, pois sua concentração praticamente não variou ao longo de seu comprimento longitudinal.

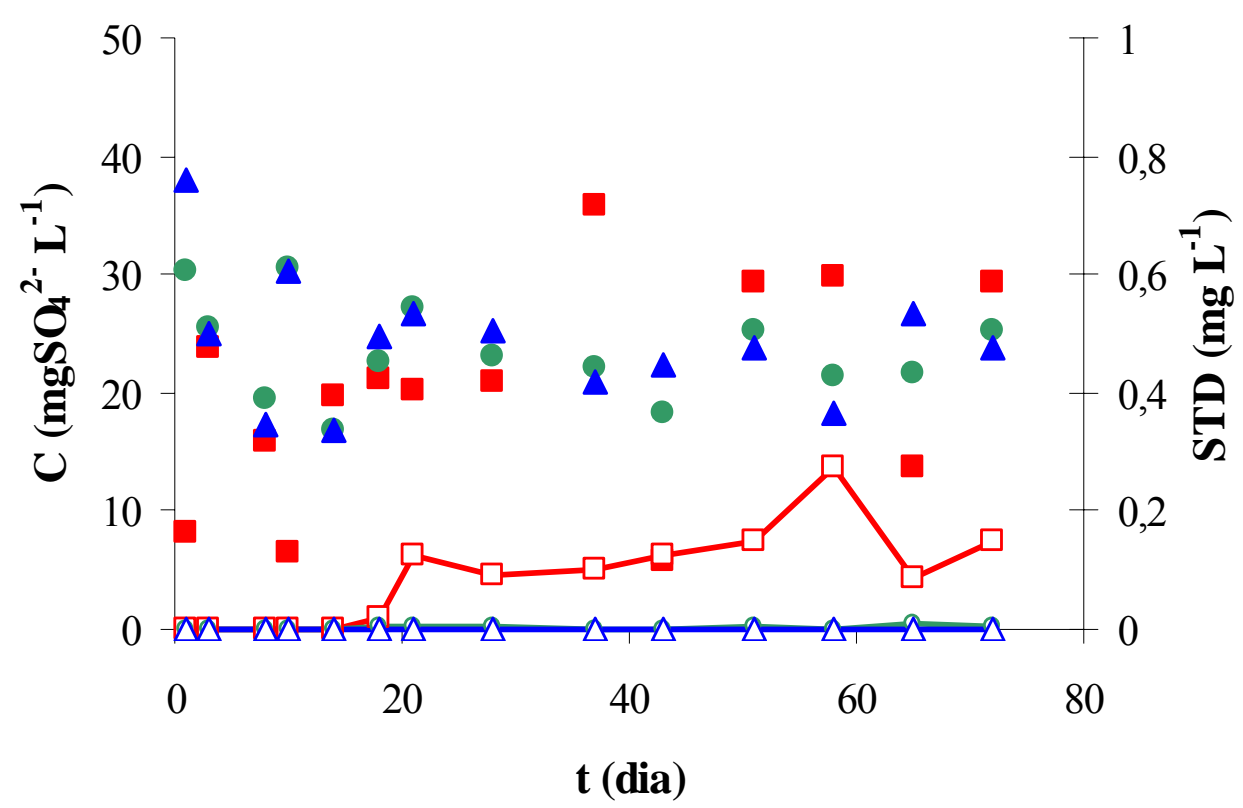

Figura 17: Comportamento das formas sulfurosas - Condição 1

Legenda:

Sulfato: - Afluente, $\bullet$ Intermediário e $\boldsymbol{\Delta}$ Efluente

Sulfeto total dissolvido (STD): - $\square$ - Afluente, - - Intermediário e - $\Delta$ - Efluente

\subsubsection{Microrganismos: acompanhamento das morfologias}

De maneira geral, o acompanhamento das morfologias presentes na câmara aeróbia do reator, por meio de microscopia óptica, permitiu constatar uma ampla gama de microrganismos na câmara aeróbia durante esta condição.

As amostras foram retiradas em 2 pontos ao longo do comprimento longitudinal da câmara aeróbia do RAALF. Com relação às amostras retiradas do compartimento aeróbio, estas se mostraram representativas de um ambiente aeróbio, apresentando diversidade de bactérias, protozoários, rotíferos, algas e nematóides, com morfologias como bacilos pequenos, cocos nitrificantes, bactérias fototróficas, filamentos, bacilos, bacilos com inclusões e cistos de protozoários. Também foi possível 
verificar a predominância de filamentos no topo da câmara aeróbia, além da presença dos mesmo na base, além de algumas espiroquetas (Figura 18).

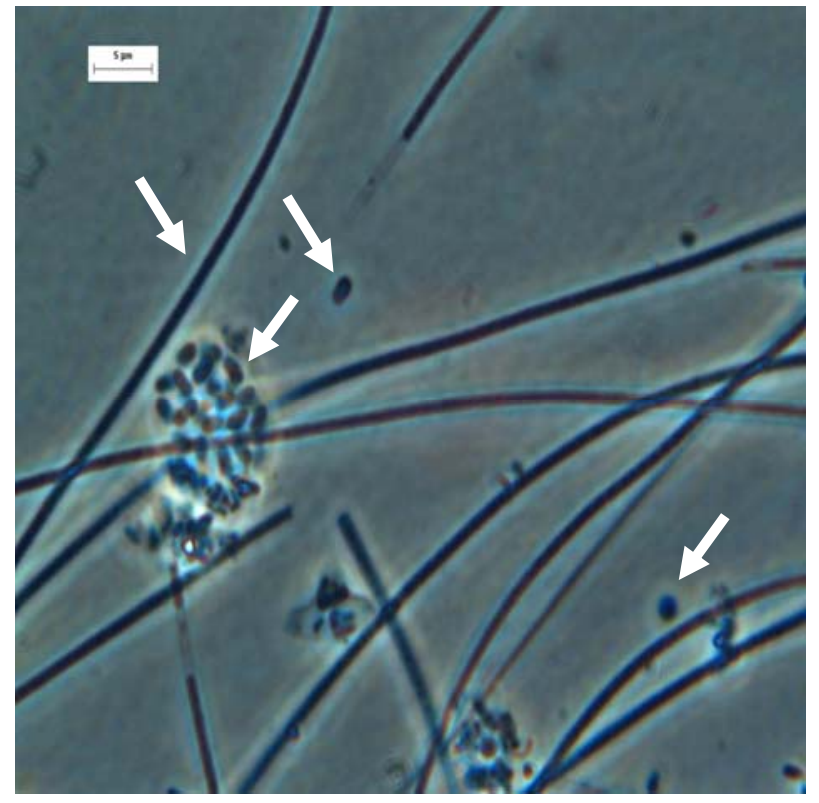

(a)

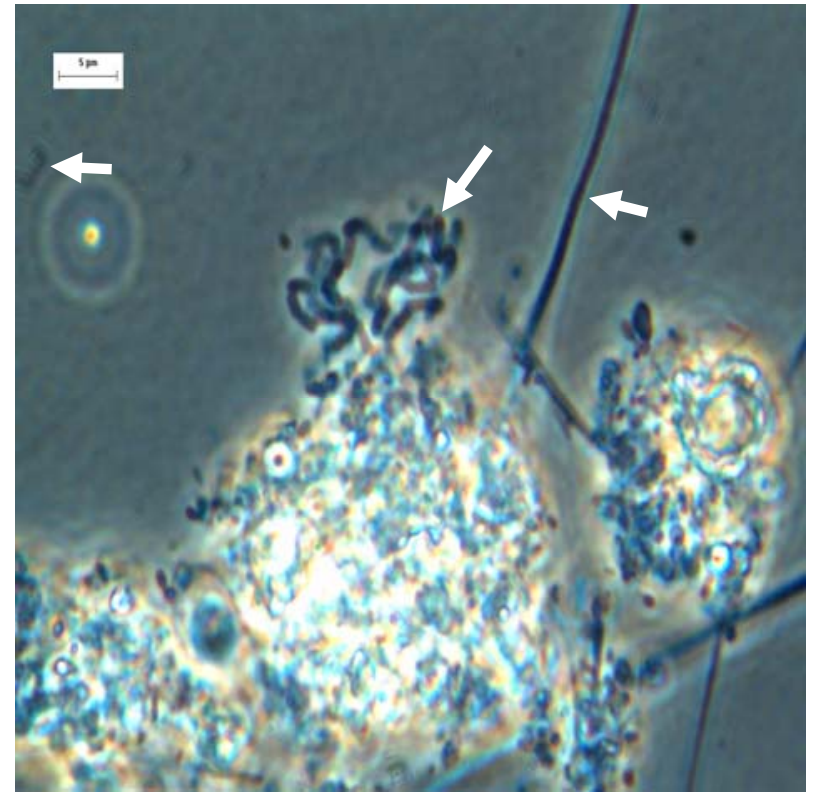

(b)

Figura 18: Amostras retiradas do topo (a) e da base (b) da câmara aeróbia - Condição 1. Predominância de morfologias filamentosas. 


\subsubsection{ANÁLISE DA CONDIÇÃO 2}

Após atingida a estabilidade no processo de nitrificação na câmara aeróbia, deu-se início à injeção de gás na câmara anóxica, com o objetivo de se obter a desnitrificação a partir dos doadores de elétrons presentes no gás.

A operação nesta condição deu-se sob um tempo de detenção hidráulico teórico ( $\theta$ h), considerando o volume útil do reator, de 3 horas na câmara aeróbia e 4,5 horas na câmara anóxica, totalizando um $\theta$ h útil total de 7,5 horas durante a sub-condição 2.1 ; de 2 horas na câmara aeróbia e de 3 horas na câmara anóxica, totalizando um $\theta$ h útil total de 5 horas durante a sub-condição 2.2; de 1 hora na câmara aeróbia e 1,5 horas na câmara anóxica, totalizando um $\theta$ h útil total de 2,5 horas durante a sub-condição 2.3 .

As vazões aplicadas para possibilitar os $\theta$ h de estudo durante as sub-etapas 2.1, 2.2 e 2.3 foram de 12,18 e $35 \mathrm{~mL} \mathrm{~min}^{-1}$.

\subsubsection{Dinâmica de remoção da matéria orgânica carbonácea}

Os resultados apresentados nos gráficos 19a e 19b, que representam as sub-condições 2.1 e 2.2, da Figura 19, confirmam o comportamento apresentado desde a etapa de partida do sistema no que tange a capacidade do sistema em absorver picos de carga orgânica. 


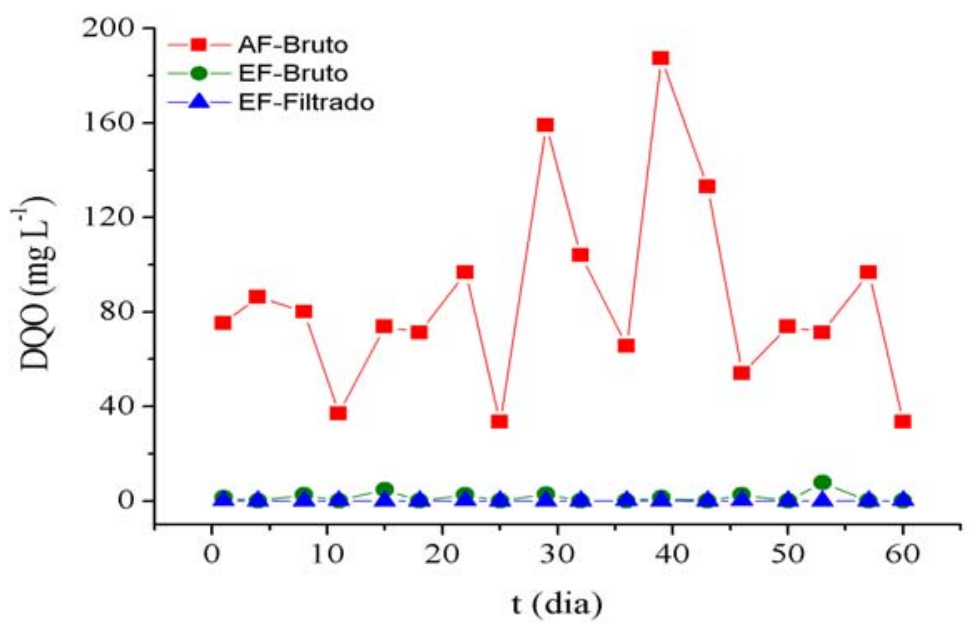

$\theta \mathrm{h}=7,5 \mathrm{~h}(\mathrm{a})$

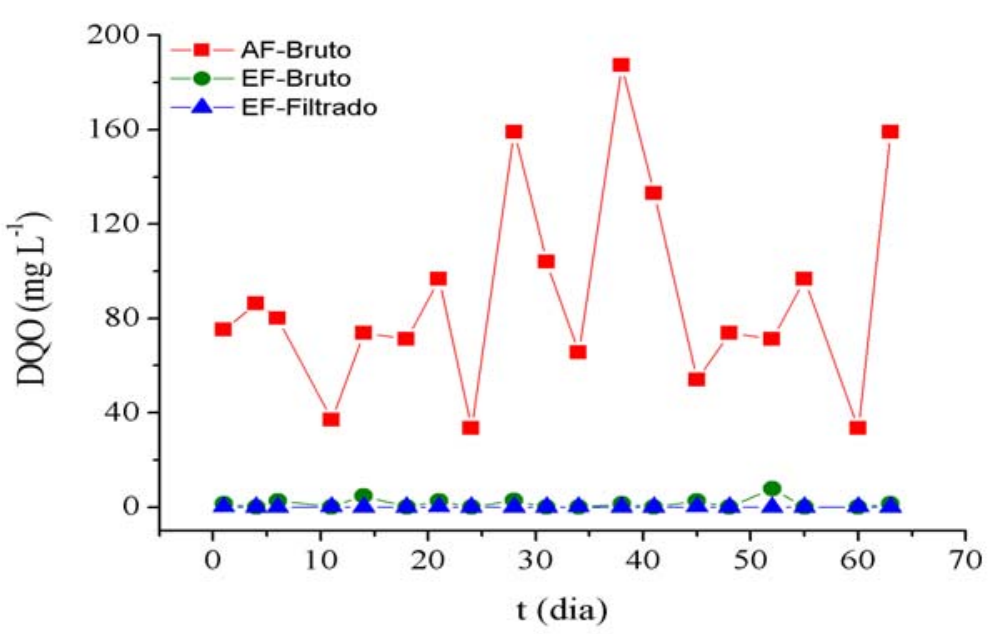

$\theta h=5 \mathrm{~h}(\mathrm{~b})$

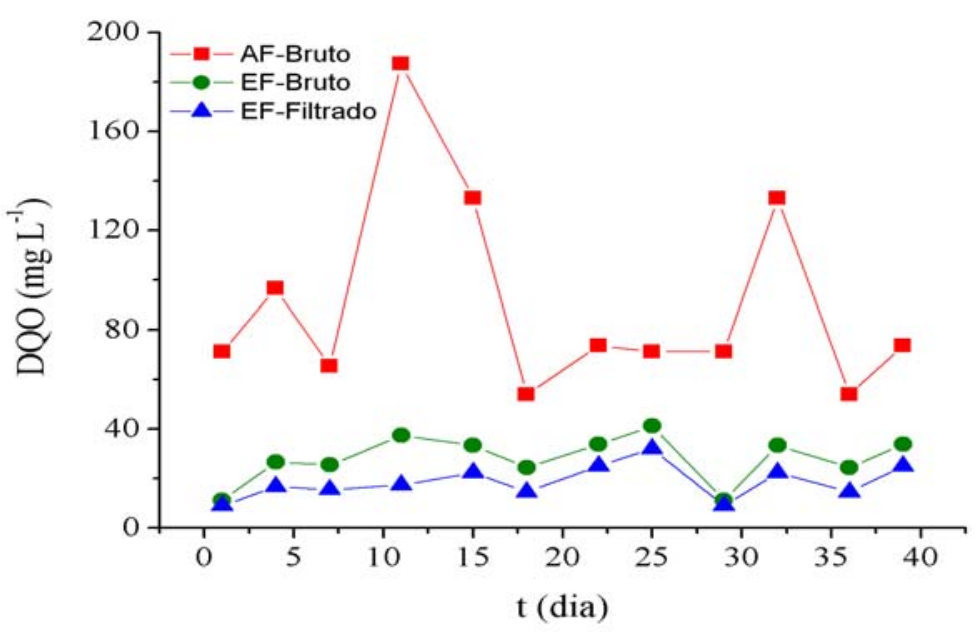

$\theta \mathrm{h}=2,5 \mathrm{~h}(\mathrm{c})$

Figura 19: Dinâmica da $\mathrm{DQO}_{\text {total }}$ - Condição 2

Sub-condição 1(a), sub-condição 2 (b) e sub-condição 3(c). 
A eficiência média de remoção de $\mathrm{DQO}_{\text {total }}$ nestas etapas foi de $98,3 \%$, o que demonstra a alta capacidade da biomassa heterótrofa na remoção de matéria orgânica. Como conseqüência da elevada eficiência de remoção de DQO na câmara aeróbia, os únicos doadores de elétrons disponíveis na câmara anóxica, durantes estas sub-etapas, foram oriundos exclusivamente do biogás sintético.

Todavia, durante a sub-condição 2.3, a eficiência média de conversão de DQO decresceu para 68,9\% na câmara aeróbia, em virtude da diminuição do $\theta$ h nesta câmara para 2,5 horas.

Sabe-se que a transferência de massa por difusão em reatores de leito fixo depende das condições hidrodinâmicas do fluido ao redor das partículas, como velocidade do fluido, diâmetro da partícula e propriedades físicas do fluido. O aumento do coeficiente de transporte de massa através do filme de fluido é proporcional ao aumento de Reynolds do sistema. Esse efeito é conseguido através do aumento da velocidade superficial do fluido (Dunn et al., 1992).

Zaiat et al. (1996) estudaram a transferência de massa na fase líquida em um reator anaeróbio horizontal de leito fixo (RAHLF) preenchido com espuma de poliuretano e verificaram que houve aumento exponencial do coeficiente de transferência de massa com a velocidade superficial do líquido, e que esta situação parecia explicar melhor o comportamento às baixas velocidades aplicadas. Todavia, os autores ressaltam que estes resultados têm aplicação restrita às condições experimentais impostas e aos limites de velocidade superficial estudadas naquele sistema $\left(25,2\right.$ a $\left.270 \mathrm{~cm} \mathrm{~h}^{-1}\right)$.

Todavia, Abreu e Zaiat (2008) avaliaram três $\theta$ h (6, 8 e 10 horas) em seu estudos com reator anaeróbio-aeróbio de leito fixo em escala de bancada no tratamento de esgoto sanitário. Verificaram que a diminuição do $\theta$ h de 8 para 6 horas, com conseqüente aumento da velocidade superficial de líquido no leito não resultou em melhorias na eficiência do processo. Pelo contrário, embora o processo tenha ocorrido de forma estável, os valores de DQO bruta efluente foram superiores quando foi aplicado $\theta$ h de 6 horas, com menor eficiência, portanto. Os resultados foram similares somente em relação ao material particulado. Dessa forma a hipótese de que o aumento das velocidades de transferência de massa líquido-sólido poderia ser fator determinante para aumento da eficiência da conversão de matéria orgânica solúvel, não foi confirmada. Partiu-se, então para a verificação da 
segunda hipótese, aumentando-se o $\theta$ h para 10 horas. Os resultados indicam claramente que a condição operacional com $\theta$ h de 10 horas foi mais efetiva que as anteriores, tanto para a eficiência global do processo quanto para a estabilidade do processo nesse caso específico.

Como as condições ambientais foram razoavelmente mantidas durante as três sub-condições e houve apenas a variação do $\theta$ h, acredita-se que este parâmetro possa ter tido papel crucial para a perda da eficiência na câmara aeróbia, pois durante as sub-condições 2.1 e 2.2 ( $\theta$ h de 7,5 e 5 horas, respectivamente), as eficiências foram bastante elevadas, conforme supracitado.

Os valores de eficiência de remoção de matéria orgânica como função do $\theta$ h mantido na câmara aeróbia (3, 2 e 1 hora para as sub-condições $2.1,2.2$ e 2.3, respectivamente) podem ser visualizados no gráfico da Figura 20.

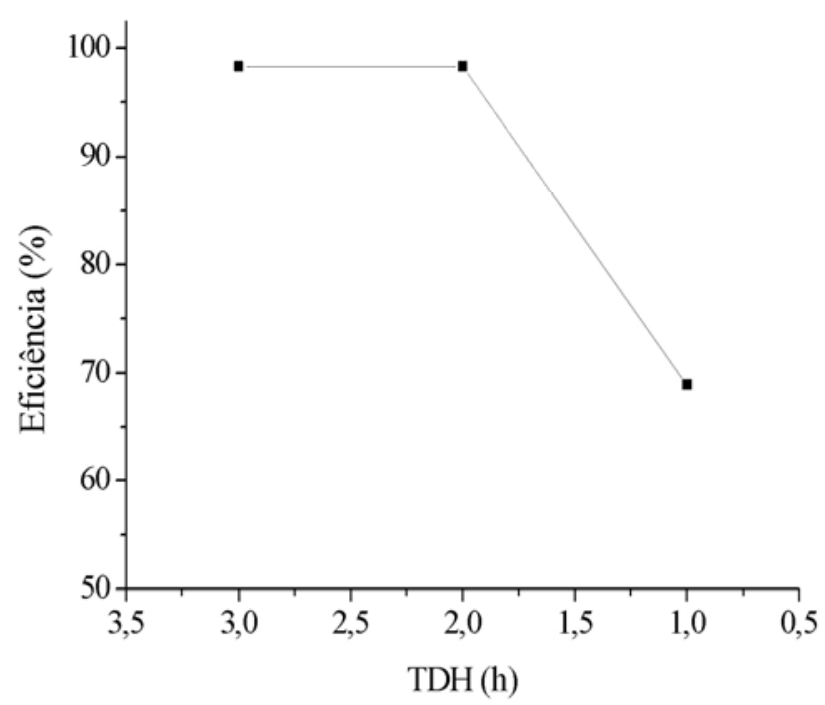

Figura 20: Eficiência de remoção de matéria orgânica carbonácea como função do $\theta$ h na câmara aeróbia (Condição 2)

Os resultados dos perfís espaciais de DQO, realizados nas sub-condições 2.1 e 2.2 (Figura 21 a,b), apontaram que praticamente toda a remoção de matéria orgânica carbonácea deu-se na primeira metade da câmara aeróbia (L/D 0,8), ou seja, repetiu-se o comportamento obtido na condição 1 nestas 
referidas sub-condições. Por outro lado, o efeito da diminuição do TDH afetou a remoção de DQO no reator, conforme pode ser observado no gráfico da Figura 21c.

Para o perfil espacial realizado na sub-condição 2.1 , tem-se que, em $\mathrm{L} / \mathrm{D} \sim 0,8$, a remoção de matéria orgânica carbonácea foi de $79,5 \%$, enquanto, na sub-condição 2.2 , o valor foi de $56 \%$. No entanto, praticamente toda a matéria orgânica foi removida nas sub-condições 2.1 e 2.2 (97,2\% e $94,2 \%$, respectivamente), o que reforça que os únicos doadores de elétrons disponíveis para a desnitrificação foram os fornecidos pelo biogás. 


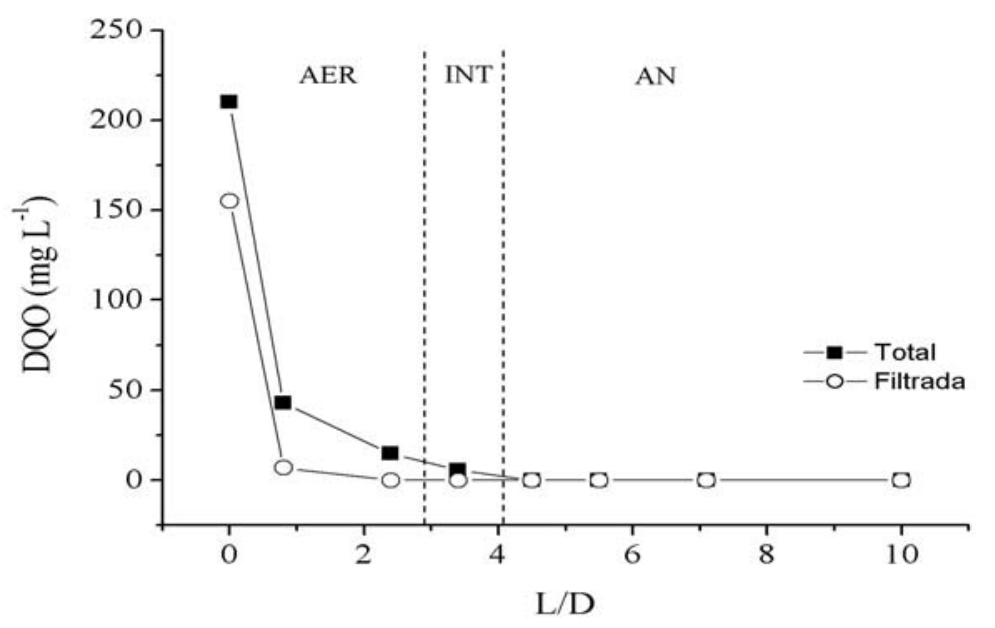

$$
\theta \mathrm{h}=7,5 \mathrm{~h}(\mathrm{a})
$$

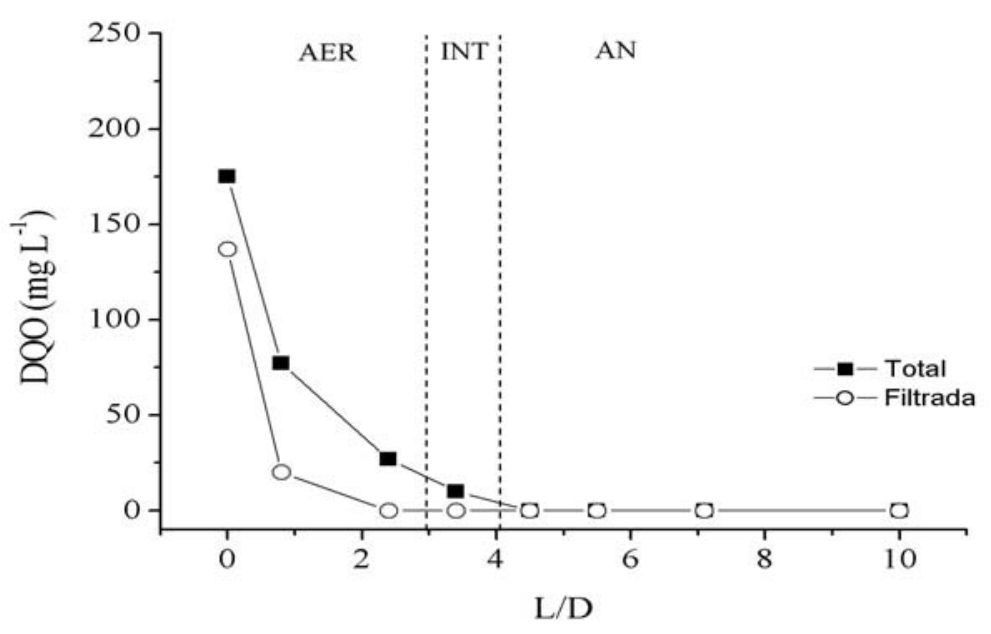

$$
\theta \mathrm{h}=5 \mathrm{~h}(\mathrm{~b})
$$

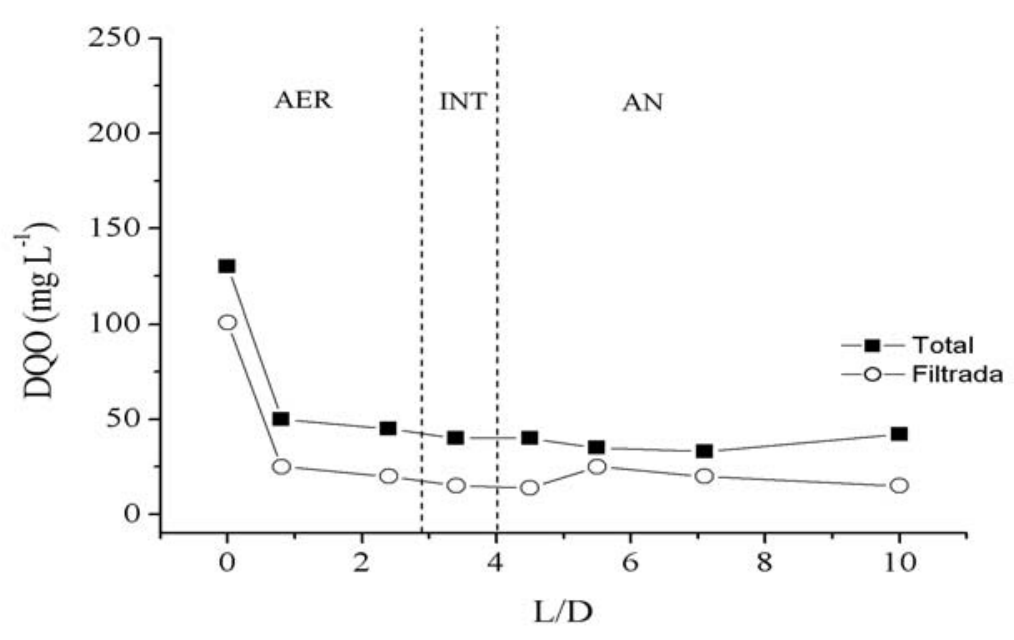

$\theta \mathrm{h}=2,5 \mathrm{~h}(\mathrm{c})$

Figura 21: Perfil espacial de DQO - Condição 2 Sub-condição 1(a), sub-condição 2 (b) e sub-condição 3(c). 
Todavia, no perfil realizado na sub-condição 2.3 , constatou-se a queda no desempenho, em comparação às duas sub-condições anteriores. A eficiência de remoção foi de $69,2 \%$ em L/D 3,4 (efluente da câmara aeróbia).

Importante destacar que, mesmo com a presença de um residual de matéria orgânica, esta não foi utilizada como doador de elétrons na câmara desnitrificante, pois, a variação da concentração de matéria orgânica, expressa em termos de DQO ao longo do reator, não foi significativa, conforme pode ser observado no gráfico da Figura 21c.

\subsubsection{Dinâmica das formas nitrogenadas}

Na Figura 22, pode ser observado o comportamento do nitrogênio amoniacal durante toda a condição 2 do trabalho. Durante a sub-condição 2.1, praticamente todo o nitrogênio amoniacal foi removido na câmara aeróbia do reator, sendo que a eficiência média de remoção foi de $95,3 \%$. A diminuição do $\theta$ h provocou a queda da eficiência para 83,3\% e para 51,7\%, nas sub-condições 2.2 e 2.3 , respectivamente.

Destaca-se, também, que a fração de nitrogênio amoniacal residual da câmara aeróbia sofreu uma ligeira alteração na sua concentração, principalmente na sub-condição 2.3. É provável que parte do nitrogênio amoniacal tenha sido utilizada pelos microrganismos para consumo endógeno na câmara desnitrificante. 


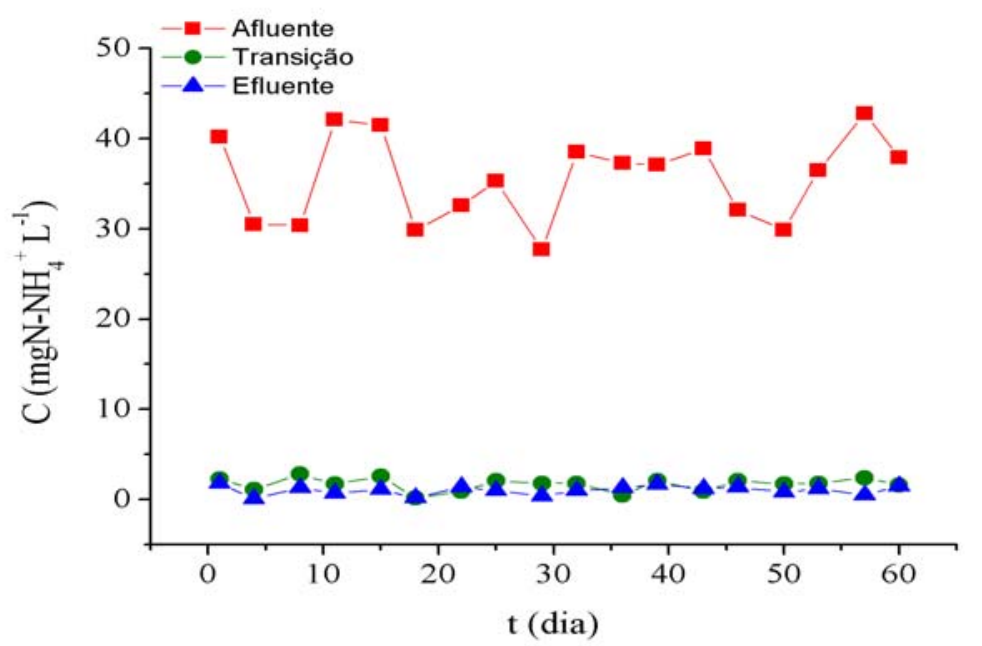

$\theta \mathrm{h}=7,5 \mathrm{~h}(\mathrm{a})$

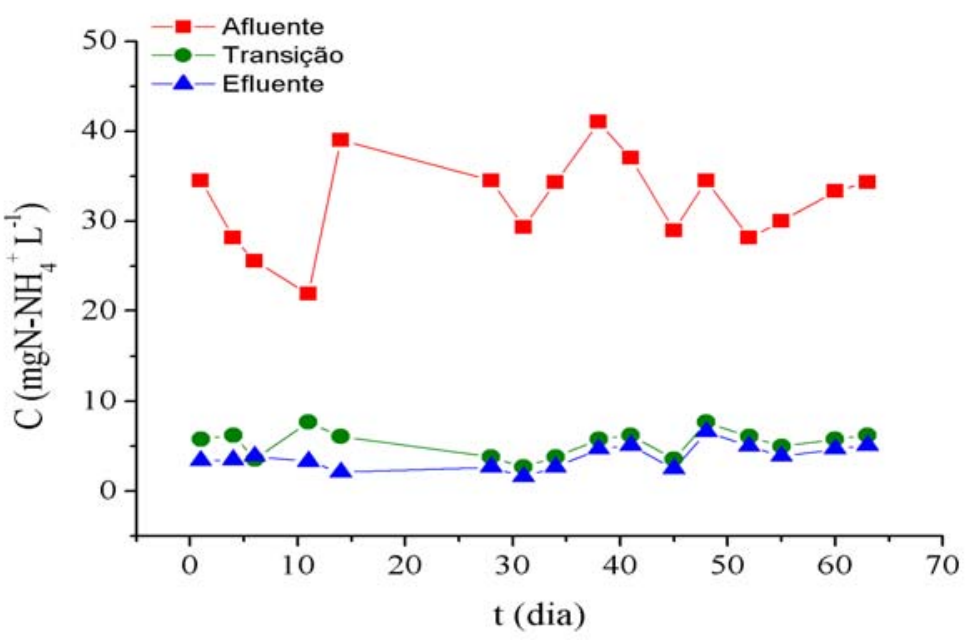

$\theta \mathrm{h}=5 \mathrm{~h}(\mathrm{~b})$

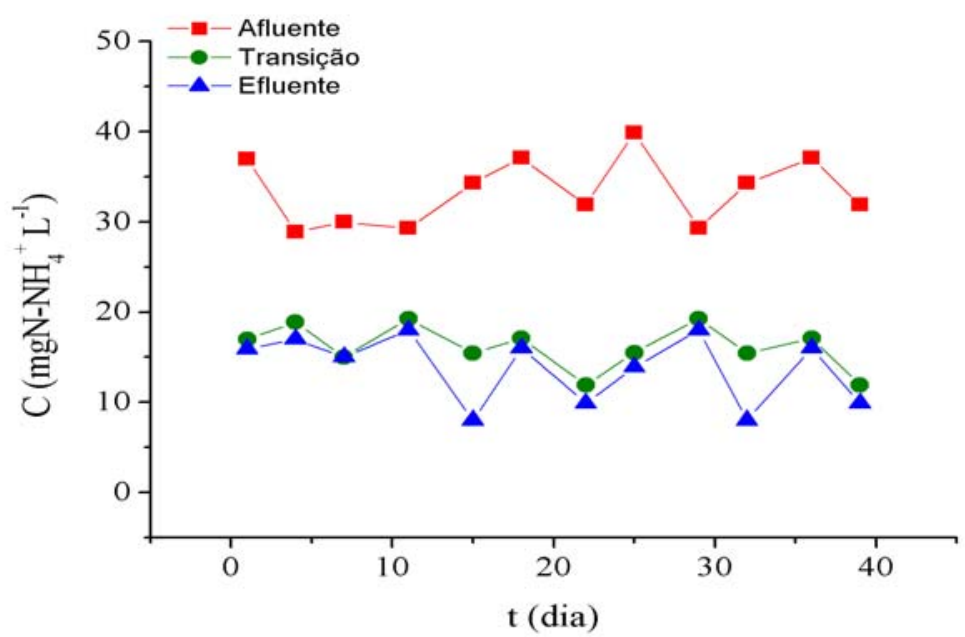

$\theta \mathrm{h}=2,5 \mathrm{~h}(\mathrm{c})$

Figura 22: Dinâmica do nitrogênio amoniacal - Condição 2 Sub-condição 1(a), sub-condição 2 (b) e sub-condição 3(c). 
Victoria (2006), operando o filtro biológico em escala piloto com duas câmaras seqüenciais sobrepostas para o polimento de efluente de reator UASB tratando esgoto sanitário, observou que o início da redução de nitrato se deu 13 dias após a injeção de biogás em seu filtro percolador. A estabilização da desnitrificação ocorreu cerca de 14 dias depois do início da redução de nitrato - após terem sido tomadas medidas para melhorar o contato gás-biomassa, como por exemplo, a submersão do material suporte e a mudança do ponto de injeção de biogás.

No RAALF, a desnitrificação atingiu seu equilíbrio dinâmico após o $7^{\circ}$ dia de injeção do biogás (dados não apresentados), não sendo necessário, portanto, um período maior de adaptação da biomassa às novas fontes de elétrons oriundas do biogás. Acredita-se que a configuração permitiu um bom contato gás-biomassa, aumentando a transferência de massa e acelerando o processo de obtenção do equilíbrio dinâmico aparente do reator.

Com auxílio dos gráficos da Figura 23 e da Tabela 13, é possível observar que o desempenho da câmara desnitrificante no tocante à redução do nitrato foi muito inferior na subcondição 2.3. Um dos motivos para a queda de desempenho foi a menor capacidade da câmara aeróbia em oxidar o nitrogênio amoniacal a nitrato, sendo assim, com menor concentração de aceptor de elétrons final, o processo foi afetado. $\mathrm{O}$ aumento da velocidade descensional também pode ter colaborado para o referido desempenho.

A produção de nitrito ao longo da operação foi praticamente desprezível. Assim, pode-se concluir que o principal produto da oxidação do nitrogênio amoniacal foi o nitrato. 


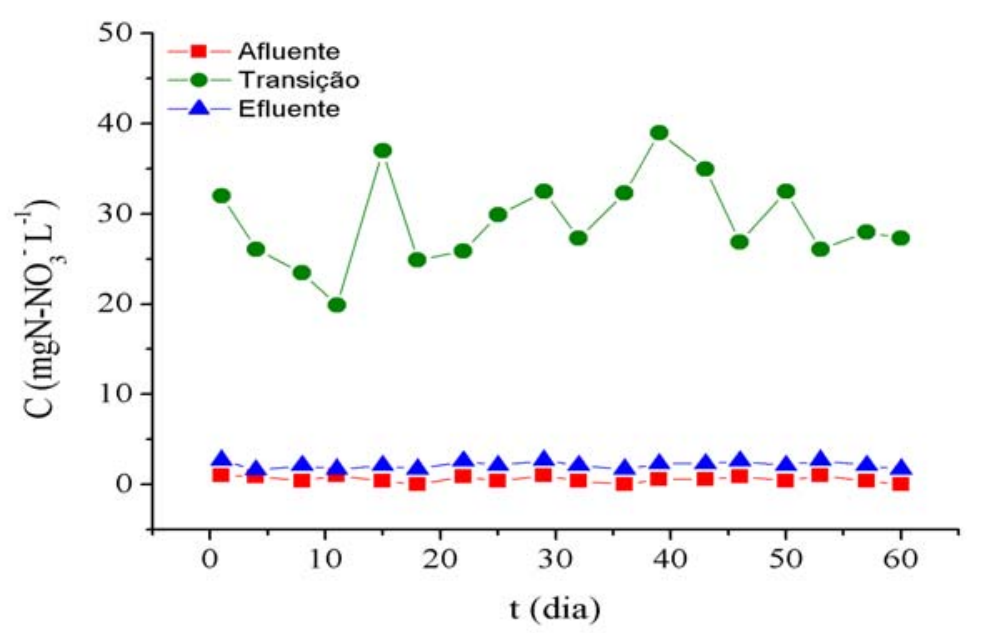

$\theta \mathrm{h}=7,5 \mathrm{~h}(\mathrm{a})$

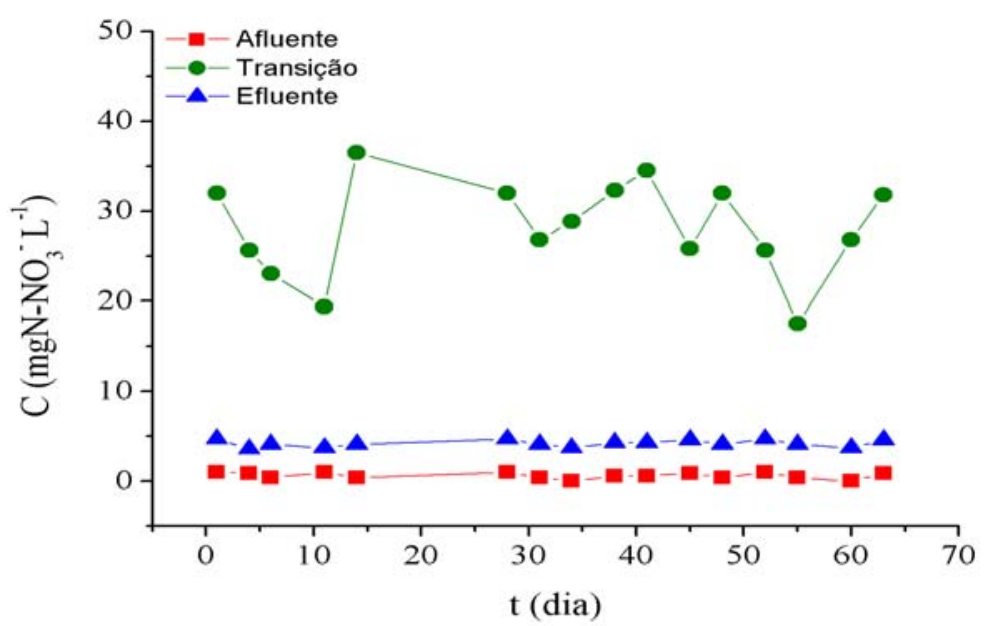

$\theta \mathrm{h}=5 \mathrm{~h}(\mathrm{~b})$

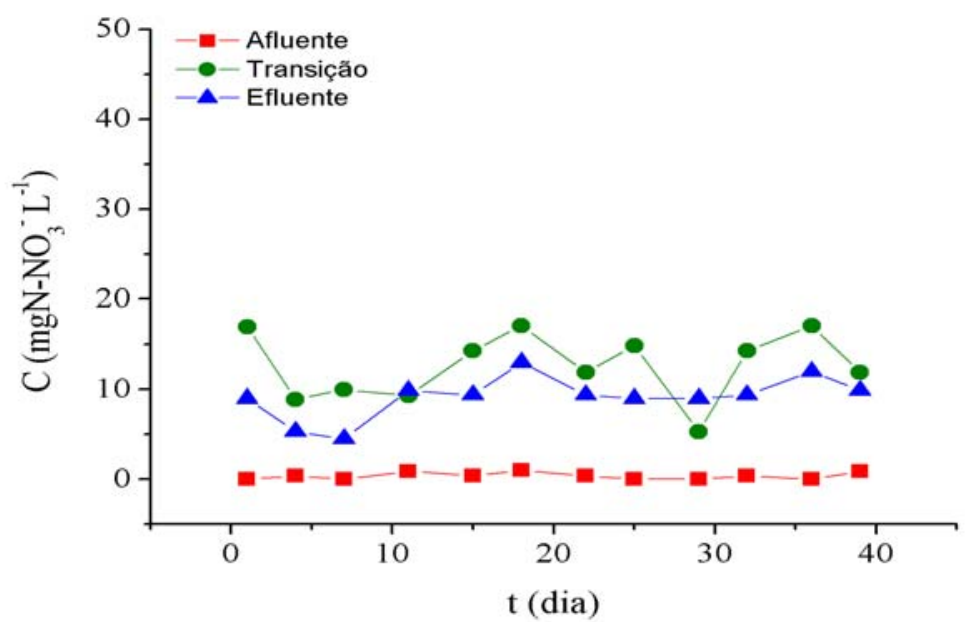

$\theta \mathrm{h}=2,5 \mathrm{~h}(\mathrm{c})$

Figura 23: Dinâmica do nitrato - Condição 2

Sub-condição 1(a), sub-condição 2 (b) e sub-condição 3(c). 
De acordo com a Tabela 13, enquanto as médias efluentes de nitrato verificadas durante as subcondições 2.1 e 2.2 foram de 2,2 $\pm 0,1$ e $4,2 \pm 0,1 \mathrm{mg} \mathrm{L}^{-1}$, na sub-condição 2.3 - a despeito da menor concentração afluente de nitrato decorrente da queda de eficiência nitrificante na câmara aeróbia - a concentração média efluente foi de $9,4 \pm 0,1 \mathrm{mg} \mathrm{L}^{-1}$.

Tabela 13: Estatística descritiva das formas nitrogenadas (Condição 2)

Formas nitrogenadas

\begin{tabular}{|c|c|c|c|c|c|c|c|c|c|}
\hline \multirow{3}{*}{ Ponto } & \multicolumn{9}{|c|}{$\mathrm{N}-\mathrm{NH}_{4}{ }^{+}\left(\mathrm{mg} \mathrm{L}^{-1}\right)$} \\
\hline & \multicolumn{3}{|c|}{ Sub-condição 2.1} & \multicolumn{3}{|c|}{ Sub-condição 2.2} & \multicolumn{3}{|c|}{ Sub-condição 2.3} \\
\hline & Mín & Máx & $\mathrm{M}$ & Mín & Máx & $\mathrm{M}$ & Mín & Máx & $\mathrm{M}$ \\
\hline Afluente & 27,7 & 42,8 & $35,6 \pm 1,1$ & 21,9 & 41,0 & $\begin{array}{c}32,1 \pm 1 \\
3\end{array}$ & 28,9 & 39,9 & $33,4 \pm 1,1$ \\
\hline Transição & 0,2 & 2,8 & $1,7 \pm 0,2$ & 2,7 & 6,6 & $5,4 \pm 0,4$ & 11,9 & 19,3 & $16,2 \pm 1,7$ \\
\hline \multirow[t]{2}{*}{ Efluente } & 0,1 & 1,8 & $1,0 \pm 0,1$ & 7,7 & 1,6 & $3,8 \pm 0,3$ & 8,0 & 18,0 & $13,8 \pm 0,1$ \\
\hline & \multicolumn{9}{|c|}{$\mathrm{N}-\mathrm{NO}_{2}{ }^{-}\left(\mathrm{mg} \mathrm{L}^{-1}\right)$} \\
\hline Afluente & 0,1 & 0,4 & $0,3 \pm 0$ & 0,1 & 0,4 & $0,3 \pm 0$ & 0,1 & 0,4 & $0,3 \pm 0$ \\
\hline Transição & 0,1 & 1,6 & $0,8 \pm 0,2$ & 0,1 & 1,0 & $1,1 \pm 0,2$ & 0,1 & 1,3 & $1,6 \pm 0,4$ \\
\hline \multirow[t]{2}{*}{ Efluente } & 0,4 & 1,1 & $0,8 \pm 0,3$ & 0,1 & 1,5 & $0,7 \pm 0,2$ & 0,8 & 1,9 & $1,3 \pm 0,5$ \\
\hline & \multicolumn{9}{|c|}{$\mathrm{N}-\mathrm{NO}_{3}{ }^{-}\left(\mathrm{mg} \mathrm{L}^{-1}\right)$} \\
\hline Afluente & 0 & 1 & $0,6 \pm 0,1$ & 0 & 1 & $0,6 \pm 0,1$ & 0 & 1 & $0,4 \pm 0,1$ \\
\hline Transição & 19,9 & 39,0 & $29,2 \pm 1,2$ & 14,4 & 36,5 & $\begin{array}{c}27,3 \pm 1 \\
3\end{array}$ & 5,3 & 17,1 & $12,7 \pm 1,1$ \\
\hline Efluente & 1,6 & 2,7 & $2,2 \pm 0,1$ & 3,6 & 4,7 & $4,2 \pm 0,1$ & 9 & 10 & $9,4 \pm 0,1$ \\
\hline
\end{tabular}

Legenda: Mín: valores mínimos; Máx: valores máximos; M: média aritmética. 


\subsubsection{Comportamento do $\mathrm{pH}$ e da Alcalinidade}

Durante a condição 2 foi adicionado bicarbonato de cálcio como fonte externa de alcalinidade com vistas a elevar os valores de $\mathrm{pH}$ em virtude de aumento na concentração de íons de hidrogênio, especialmente devido a inserção de dióxido de carbono - constituinte da mistura gasosa presente no cilindro de biogás sintético- na massa líquida e sua conversão para ácido carbônico, de acordo com a reação (Equação 28).

$$
\mathrm{CO}_{2}+\mathrm{H}_{2} \mathrm{O} \longrightarrow \mathrm{H}_{2} \mathrm{CO}_{3} \longrightarrow \mathrm{HCO}_{3}^{-}+\mathrm{H}^{+}
$$

Equação 28

Este procedimento mostrou-se adequado do ponto de vista da manutenção do equilíbrio iônico dentro do reator, com vistas a proporcionar a condição ambiental favorável para a ocorrência dos processos de interesse. Na Tabela 14, podem ser verificados os resultados obtidos em termos de $\mathrm{pH}$ e alcalinidade durante a condição 2 da pesquisa.

A desnitrificação autótrofa consome alcalinidade (Equação 7-10), portanto é necessário garantir valores adequados de $\mathrm{pH}$. Por outro lado, a desnitrificação heterótrofa produz alcalinidade durante o processo (Equação 5 e Equação 6). Conseqüentemente, a alternativa de combinar ambientes autótrofos e heterótrofos para desnitrificação pode significar uma vantagem no que se refere ao consumo de alcalinidade, sendo que o aumento da alcalinidade gerado pela desnitrificação heterótrofa pode, de alguma maneira, diminuir os efeitos sobre a alcalinidade que a desnitrificação autótrofa produz.

Por esse motivo, acredita-se que, no caso da ocorrência simultânea da desnitrificação heterótrofa e desnitrificação autótrofa no RAALF, onde uma alcalinidade é produzida e outra é consumida, a avaliação do comportamento do $\mathrm{pH}$ e da alcalinidade na desnitrificação torna-se muito complexa. 
As médias dos valores de $\mathrm{pH}$ apontam que as condições dentro do RAALF em ambas as câmaras eram ligeiramente básicas nesta etapa, sendo mantidas dentro de faixa que não interferisse nos processos biológicos de interesse.

Tabela 14: Comportamento médio do pH e da alcalinidade (Condição 2)

\begin{tabular}{|c|c|c|c|c|c|c|c|c|c|}
\hline \multirow{3}{*}{ Ponto } & \multicolumn{9}{|c|}{ pH (unidades) } \\
\hline & \multicolumn{3}{|c|}{ Sub-condição 2.1} & \multicolumn{3}{|c|}{ Sub-condição 2.2} & \multicolumn{3}{|c|}{ Sub-condição 2.3} \\
\hline & Mín & Máx & $\mathrm{M}$ & Mín & Máx & $\mathrm{M}$ & Mín & Máx & $\mathrm{M}$ \\
\hline Afluente & 6,8 & 7,4 & $7,0 \pm 0,2$ & 6,0 & 7,4 & $7 \pm 0,3$ & 6,9 & 7,3 & $7,1 \pm 0,2$ \\
\hline Transição & 5,3 & 8,6 & $7,9 \pm 0,6$ & 7,0 & 8,6 & $7,9 \pm 0,4$ & 7,4 & 8,4 & $7,9 \pm 0,3$ \\
\hline Efluente & 5,2 & 7,9 & $7,3 \pm 0,5$ & 6,8 & 7,9 & $7,3 \pm 0,4$ & 7,6 & 8,4 & $8,0 \pm 0,3$ \\
\hline & \multicolumn{9}{|c|}{ Alcalinidade Total $\left(\mathrm{mg} \mathrm{CaCO} \mathrm{L}^{-1}\right)$} \\
\hline Afluente & 124 & 218 & $185 \pm 39$ & 129 & 212 & $182 \pm 36$ & 142 & 243 & $203 \pm 35$ \\
\hline Transição & 112 & 222 & $172 \pm 26$ & 125 & 221 & $157 \pm 24$ & 113 & 213 & $167 \pm 26$ \\
\hline Efluente & 81 & 177 & $121 \pm 28$ & 89 & 157 & $117 \pm 27$ & 103 & 203 & $154 \pm 24$ \\
\hline
\end{tabular}

Legenda: Mín: valores mínimos; Máx: valores máximos; M: média aritmética. 


\subsubsection{Oxigênio dissolvido e potencial redox}

Os perfis espaciais de oxigênio dissolvido (Figura 24), realizados durante esta condição, revelaram que o reator possuía diferentes regiões sob o ponto de vista da presença de oxigênio, classificadas como:

- estrato aeróbio - câmara aeróbia (com OD na faixa de $2 \pm 0,6 \mathrm{mg} \mathrm{L}^{-1}$ e pOR positivo, acima de $0 \mathrm{mV}$ ); - estrato aerofílico - região da câmara anóxica adjacente ao ponto de injeção de oxigênio (com OD oscilando entre 0,5 e $1 \mathrm{mg} \mathrm{L}^{-1}$ e pOR negativo, em torno de $-275 \mathrm{mV}$ );

- estrato efetivamente anóxico (com OD inferior a $0,5 \mathrm{mg} \mathrm{L}^{-1}$ e OR negativo, variando entre -300 e $250 \mathrm{mV})$.

Tais condições ambientais permitiram a ocorrência de diversos processos de interesse ao longo do reator, principalmente na câmara desnitrificante, como a oxidação parcial do metano a compostos intermediários, além da oxidação do sulfeto pelo grupo de microrganismos desnitrificantes autotróficos.

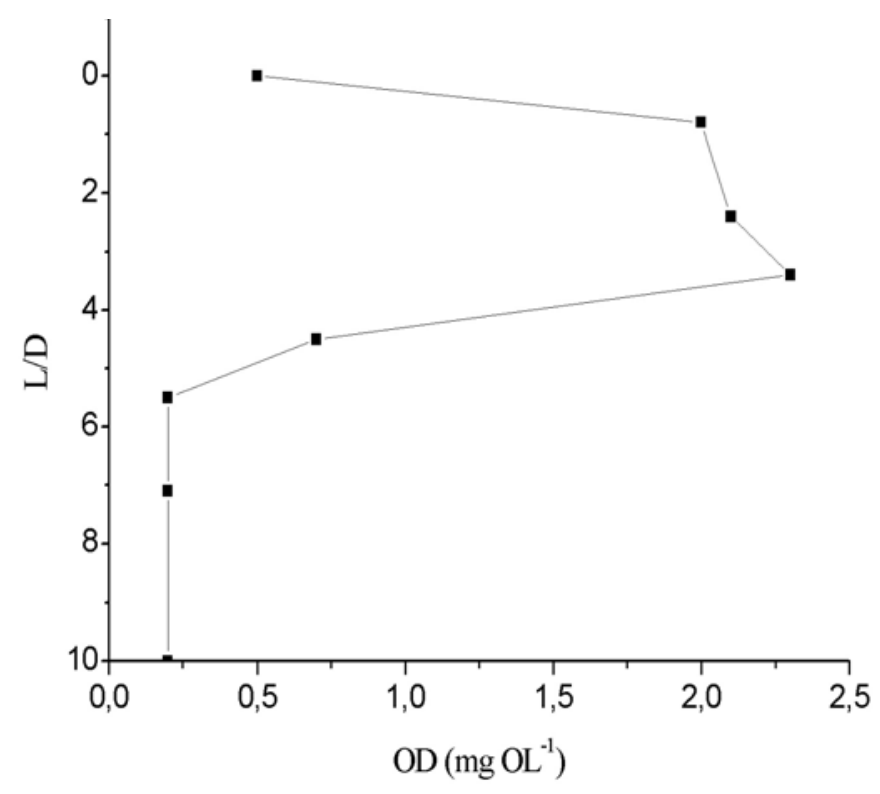

Figura 24: Perfil espacial de oxigênio dissolvido Aer: câmara aeróbia; Int: câmara intermediária; An: câmara anóxica 


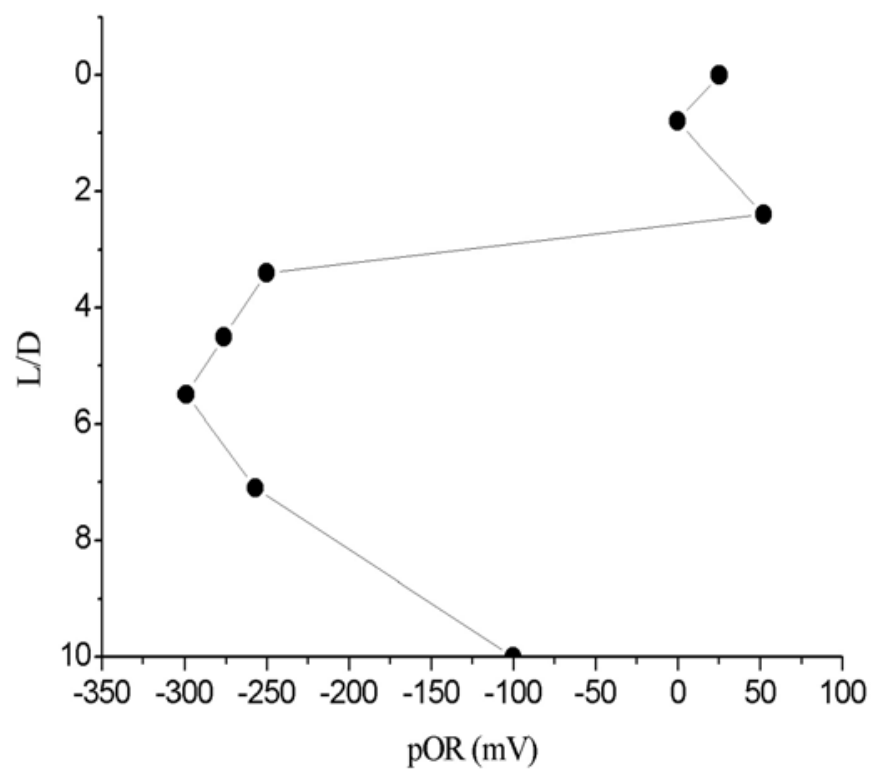

Figura 25: Perfil espacial de potencial de óxido redução - Condição 2 Aer: câmara aeróbia; Int: câmara intermediária; An: câmara anóxica

Com relação ao potencial redox, o resultado do perfil espacial acompanhou àquele observado no perfil de oxigênio dissolvido. Os valores oscilaram de levemente positivos na câmara aeróbia para altamente negativos na câmara anóxica, especialmente nas seções inferiores desta (Figura 25).

\subsubsection{Dinâmica da desnitrificação com biogás}

A partir do início da injeção de biogás na condição 2, foi observado ligeiro aumento na concentração de sulfato na câmara aeróbia com relação à condição 1, provavelmente devido à passagem do sulfeto remanescente da câmara desnitrificante, tendo em vista que o fluxo da fase gasosa no RAALF foi ascendente. Este incremento na concentração de sulfato, na câmara aeróbia, foi verificado em todas as sub-condições da condição 2 de operação, e pode ser verificado com base nos gráficos da Figura 27.

Esses resultados indicam que a câmara aeróbia serviu para "polir" (Figura 26) o sulfeto remanescente oriundo da câmara anóxica. As reações biológicas gerais que descrevem o processo ocorrido na câmara aeróbia estão representadas na Equação 29 e Equação 30 (Oyarzún et al., 2003): 


$$
2 \mathrm{HS}^{-}+\mathrm{O}_{2} \rightarrow 2 \mathrm{~S}^{0}+2 \mathrm{OH}^{-}
$$

Equação 29

$$
2 \mathrm{~S}^{0}+3 \mathrm{O}_{2} \rightarrow 2 \mathrm{SO}_{4}{ }^{2-}+2 \mathrm{H}^{+}
$$

Equação 30

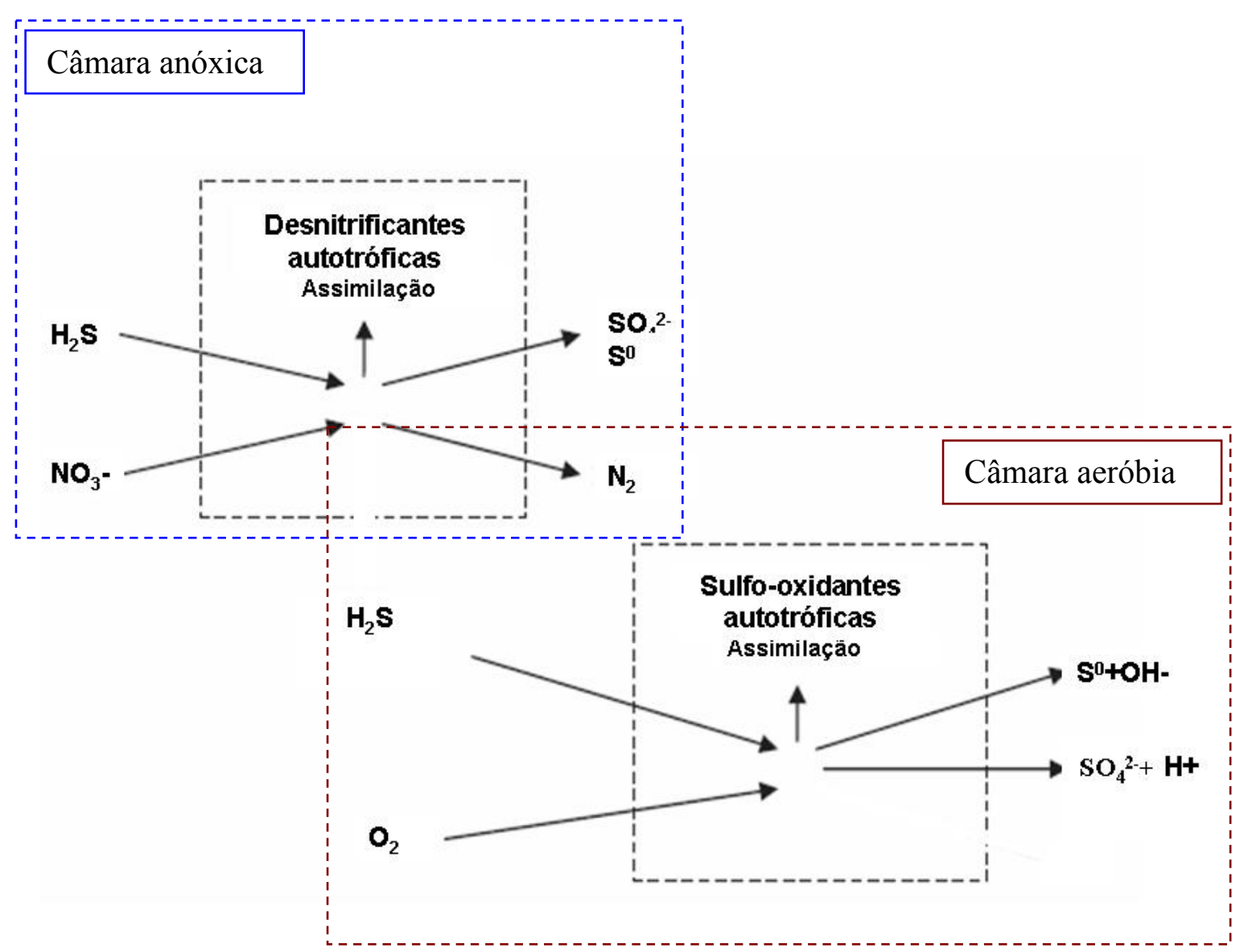

Figura 26: Esquema da dinâmica de consumo de sulfeto dentro do RAALF sob diferentes condições ambientais

O sulfeto não utilizado na câmara anóxica no processo de redução de sulfato adentra a câmara aeróbia e é oxidado pelos organismos autotróficos aeróbios, evidenciando a atuação da câmara aeróbia como componente "polidor" no tratamento do biogás.

Com relação à desnitrificação durante a condição 2, esta ocorreu de forma estável, principalmente devido ao fato de a concentração de sulfeto de hidrogênio aplicado e disponível para a biomassa autotrófica desnitrificante estar em concentração elevada. O processo autotrófico de redução de nitrato só enfrentou algum desequilíbrio durante a sub-condição 2.3 , provavelmente em virtude da 
alteração do comportamento hidrodinâmico do reator, que foi resultado da diminuição do $\theta$ h de 5 horas na sub-condição 2.2 para 2,5 horas na sub-condição 2.3 .

A concentração de oxigênio dissolvido medida no estrato efetivamente anóxico da câmara desnitrificante, durante todo o experimento, não ultrapassou $0,5 \mathrm{mg} \mathrm{L}^{-1}$, valor inferior ao sugerido pela literatura para o sucesso da utilização de compostos reduzidos de enxofre como doadores de elétrons para a desnitrificação (Sublette et al., 1998). 


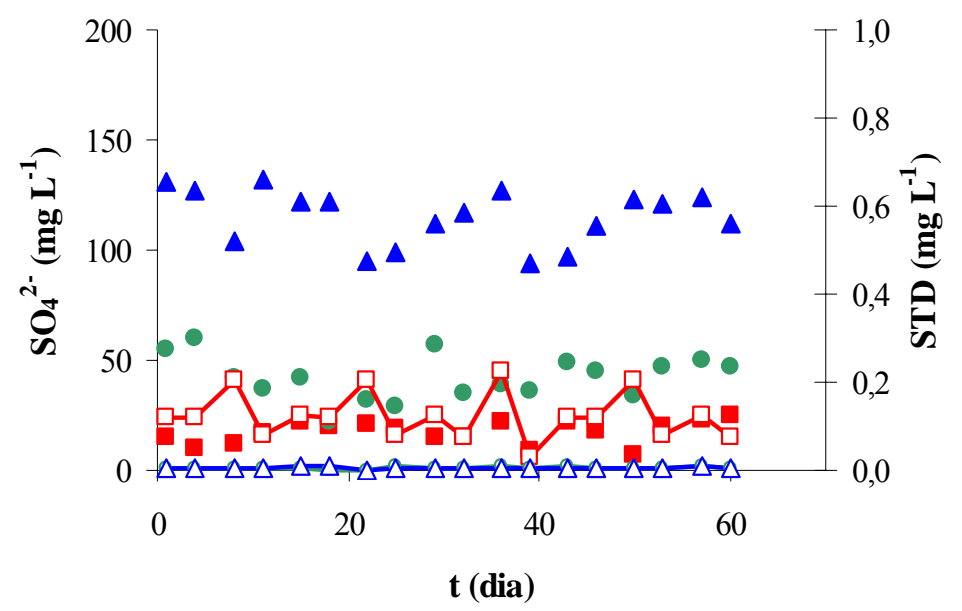

$$
\theta \mathrm{h}=7,5 \mathrm{~h}(\mathrm{a})
$$

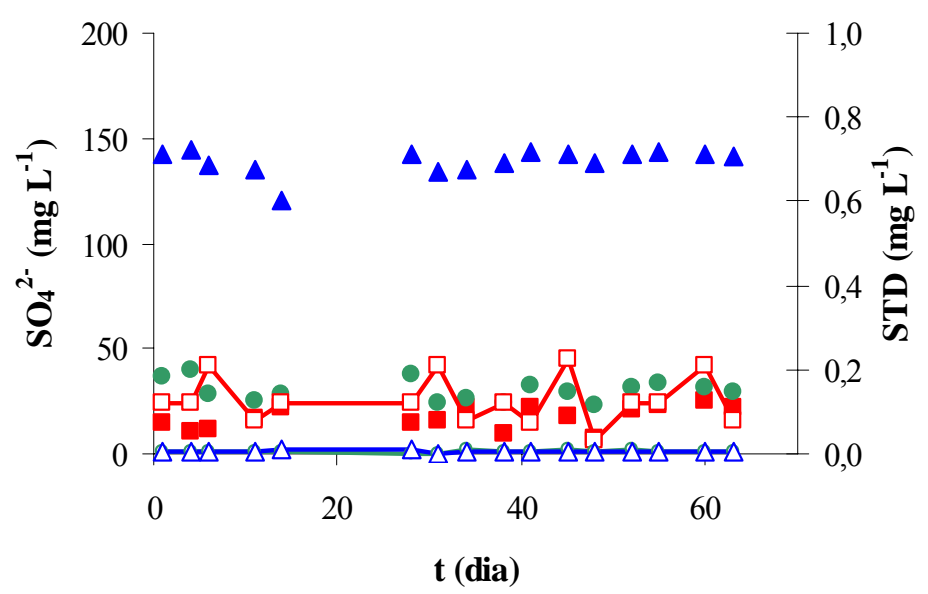

$$
\theta \mathrm{h}=5 \mathrm{~h}(\mathrm{~b})
$$

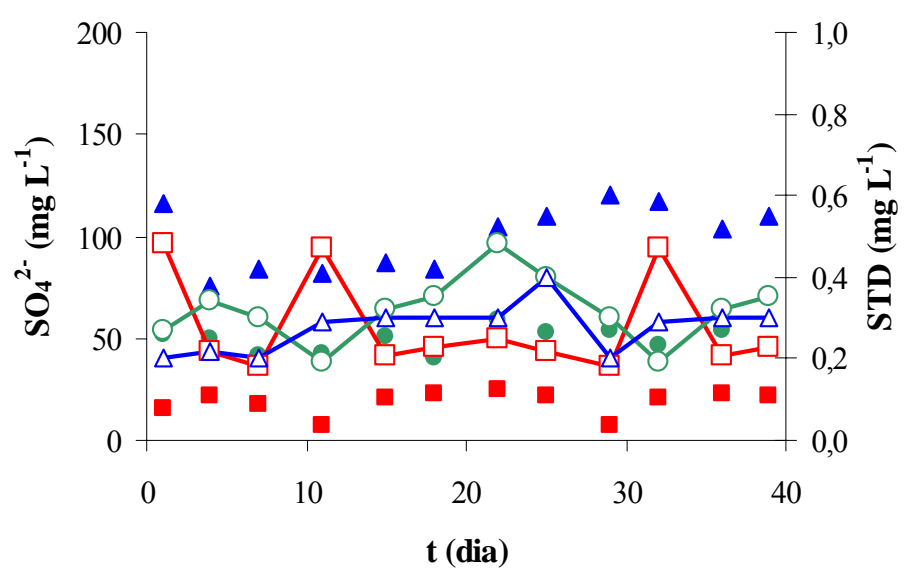

$$
\theta \mathrm{h}=2,5 \mathrm{~h}(\mathrm{c})
$$

Sulfato: a Afluente, $\bullet$ Intermediário e $\boldsymbol{\Delta}$ Efluente STD: - $\square$ - Afluente, - - Intermediário e - $\Delta$ - Efluente

Figura 27: Comportamento das formas de enxofre - Condição 2

Sub-condição 1(a), sub-condição 2 (b) e sub-condição 3(c). 
O sulfato é um dos produtos finais da oxidação de nitrogênio amoniacal pela via da desnitrificação autotrófica (Equação 8 e Equação 10, no item 3.2.2.2.1 Compostos de enxofre). Durante esta condição foi detectada concentração substancial deste composto na câmara anóxica. A concentração média de sulfato afluente na sub-condição 2.1 foi de $42,1 \pm 2,4 \mathrm{mg} \mathrm{L}^{-1}$, de $30 \pm 1,3 \mathrm{mg} \mathrm{L}^{-1}$ na sub-condição 2.2 e de 49,2 $\pm 1,6 \mathrm{mg} \mathrm{L}^{-1}$ na sub-condição 2.3 , enquanto as concentrações efluentes foram de $130 \pm 1,3 \mathrm{mg} \mathrm{L}{ }^{-1}, 138,9 \pm 1,0$ e 99,5 $44,6 \mathrm{mg} \mathrm{L}-1$ nas sub-condições $2.1,2.2$ e 2.3 respectivamente (Figura 27).

Nesta etapa, na qual o sulfeto de hidrogênio foi adicionado em alta concentração $\left(50 \mathrm{~g} \mathrm{~m}^{-3}\right)$, a concentração de sulfato foi inferior à esperada, o que sugere a formação de compostos intermediários de enxofre como, por exemplo, o enxofre elementar. Ademais, foi possível verificar, visualmente, mudanças no aspecto da fase líquida dentro da câmara anóxica para um tom ligeiramente amarelado. Esta observação também foi feita por Moraes (2009) e Beristain-Cardoso et al. (2006) em reatores em batelada, quando da avaliação da influência de diferentes relações $\mathrm{N} / \mathrm{S}$ sobre a desnitrificação autotrófica.

No caso da sub-condição 2.3 o declínio vertiginoso da concentração de sulfato efluente ao reator em comparação com as duas sub-condições anteriores, pode ter sido causado pelo aumento da velocidade descensional provocando um "efeito em cascata", pois nesta condição a oxidação do nitrogênio amoniacal a nitrato decresceu na câmara aeróbia (Figura 22 e Figura 23). Portanto, com menor quantidade de receptor final disponível na câmara anóxica, menos sulfeto foi utilizado para processar a reação, o que resultou na baixa concentração de produtos finais da reação de desnitrificação autotrófica, sendo o sulfato um desses produtos.

Os resultados da composição química da superfície do material suporte estão apresentados na Tabela 15. 
Tabela 15: Composição química da superfície do material suporte.

$(\%)$

\begin{tabular}{ccccccc} 
Elemento & \multicolumn{2}{c}{ Sub-condição 2.1} & \multicolumn{2}{c}{ Sub-condição 2.2} & \multicolumn{2}{c}{ Sub-condição 2.3} \\
\cline { 2 - 6 } & ZMA & ZEA & ZMA & ZEA & ZMA & ZEA \\
\cline { 2 - 6 } Al & 11,34 & 10,02 & 11,14 & 16,49 & 16,16 & 20,64 \\
Si & 23,30 & 15,55 & 19,49 & 37,50 & 27,99 & 23,12 \\
$\mathrm{P}$ & 20,73 & 22,21 & 4,33 & 10,37 & 12,96 & 13,29 \\
$\mathrm{~S}$ & 12,07 & 18,08 & 6,51 & 13,77 & 6,39 & 12,87 \\
$\mathrm{Ca}$ & 6,95 & 4,98 & 16,20 & 6,33 & 7,02 & 7,74 \\
$\mathrm{Fe}$ & 24,60 & 30,17 & 42,33 & 15,55 & 22,70 & 29,73 \\
\hline
\end{tabular}

ZMA = Zona de MicroAerofilia - câmara anóxica

$\mathrm{ZEA}=$ Zona Efetivamente Anóxica - câmara anóxica

Não houve grande variação percentual significativa nos resultados obtidos por meio da espectroscopia de dispersão de raios X (EDX), nas amostras retiradas da câmara anóxica, durante a condição 2, com relação ao elemento de interesse (enxofre). Mas é possível verificar uma tendência de maior percentual do referido elemento químico detectado na zona efetivamente anóxica da câmara anóxica, em todas as sub-etapas da etapa 2. Ademais, foi possível verificar visualmente a tonalidade amarelada na câmara desnitrificante, o que, de certa forma, corrobora os dados da análise qualitativa realizada, o EDX.

Os perfis espaciais de sulfato realizados apontaram que a concentração deste composto apresentou seus maiores valores nos pontos mais próximos ao ponto de introdução do biogás (na base do reator), com a tendência a diminuir na medida em que o gás ascendia pelo RAALF, conforme apresentado no gráfico da Figura 28. Este comportamento da concentração de sulfato ao longo do reator também foi verificado por Victoria (2006), em reator de leito fixo utilizado para o polimento de esgoto sanitário oriundo de reator UASB . 


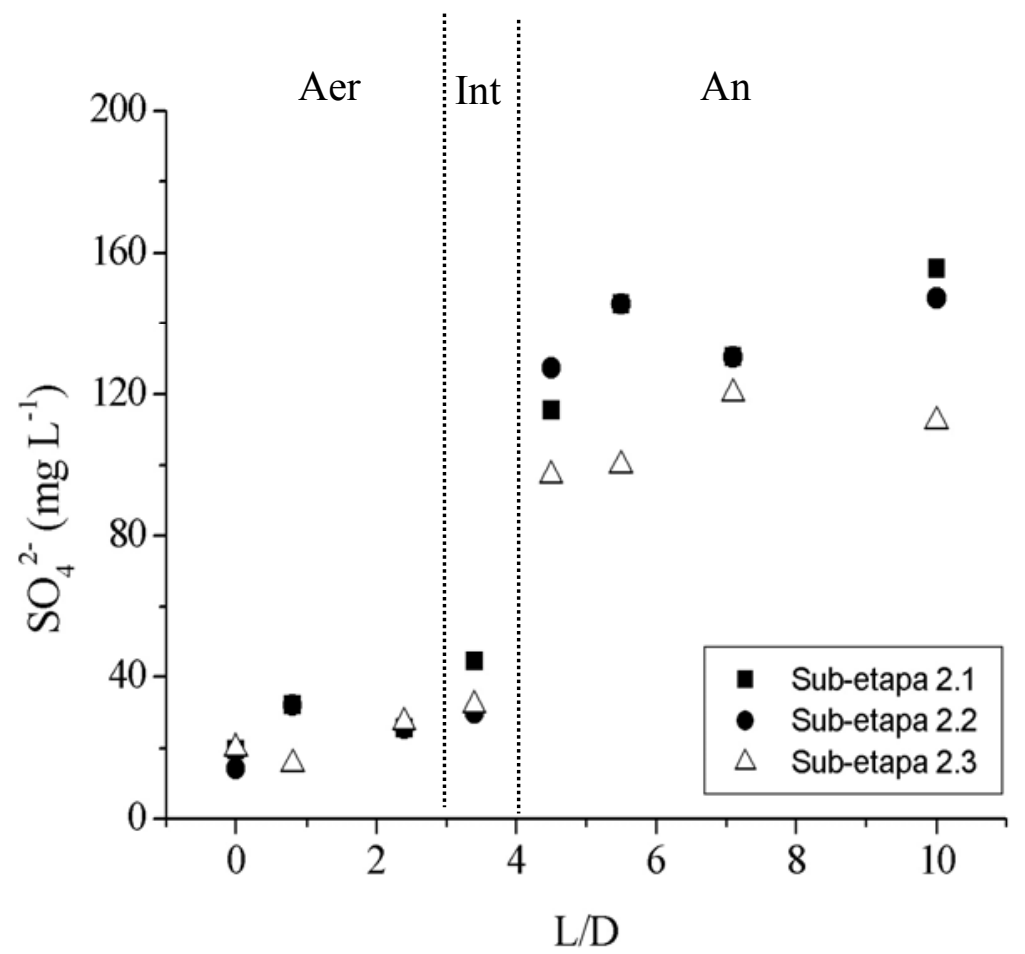

Figura 28: Perfís espaciais de concentração de sulfato - Condição 2 Aer: câmara aeróbia; Int: câmara intermediária; An: câmara anóxica

Em tese, o metanol, o formaldeído e o formiato são os produtos intermediários mais importantes produzidos na condição de desnitrificação mixotrófica (consórcio de microrganismos metanotróficos e desnitrificantes). Existe, também, a possibilidade da formação de citratos, polissacarídeos, proteínas e acetato (Thalasso et al., 1997; Rajapakse e Scutt, 1999). 


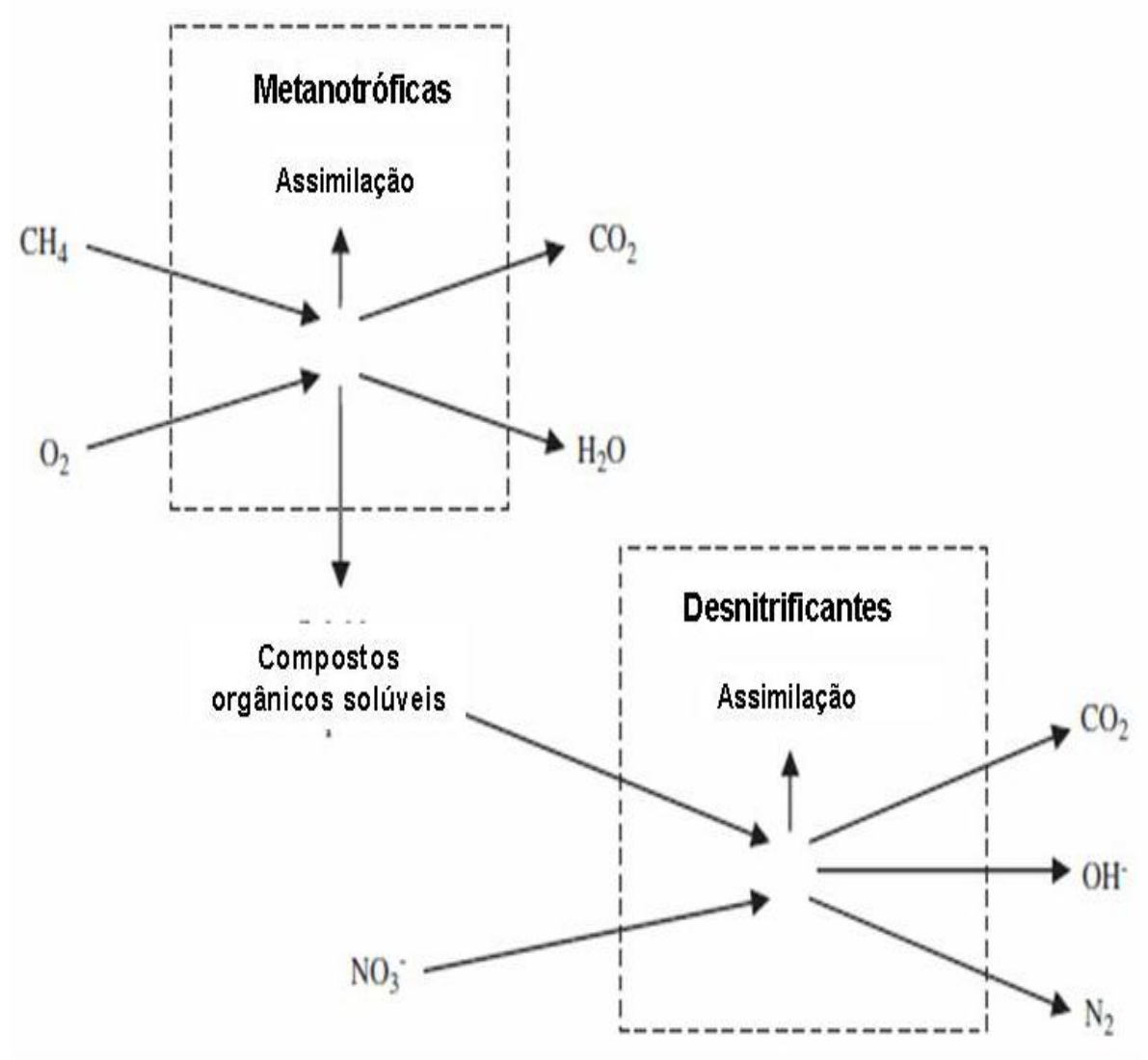

Figura 29: Oxidação anaeróbia do metano associada à desnitrificação

O único produto intermediário possível preconizado pela literatura e detectado durante os experimentos foi o metanol. Os perfis verticais de concentração de metanol indicaram que sua produção ocorreu somente em uma região específica da câmara anóxica (Figura 30), classificada como “estrato microaerofílico”, cujo OD oscilou durante toda a operação entre 0,5 e 1 mg L ${ }^{-1}$.

De acordo com Rajapakse e Scutt (1999), a concentração de oxigênio dissolvido necessária para a oxidação parcial do metano a metanol deve ser mantida abaixo de $1 \mathrm{mg} \mathrm{L}^{-1}$, caso contrário, o metano pode ser oxidado diretamente a dióxido de carbono. Portanto, sob este ponto de vista, as condições ambientais promovidas por esta região, adjacente à câmara de transição, estiveram propícias à ocorrência deste processo em específico. 


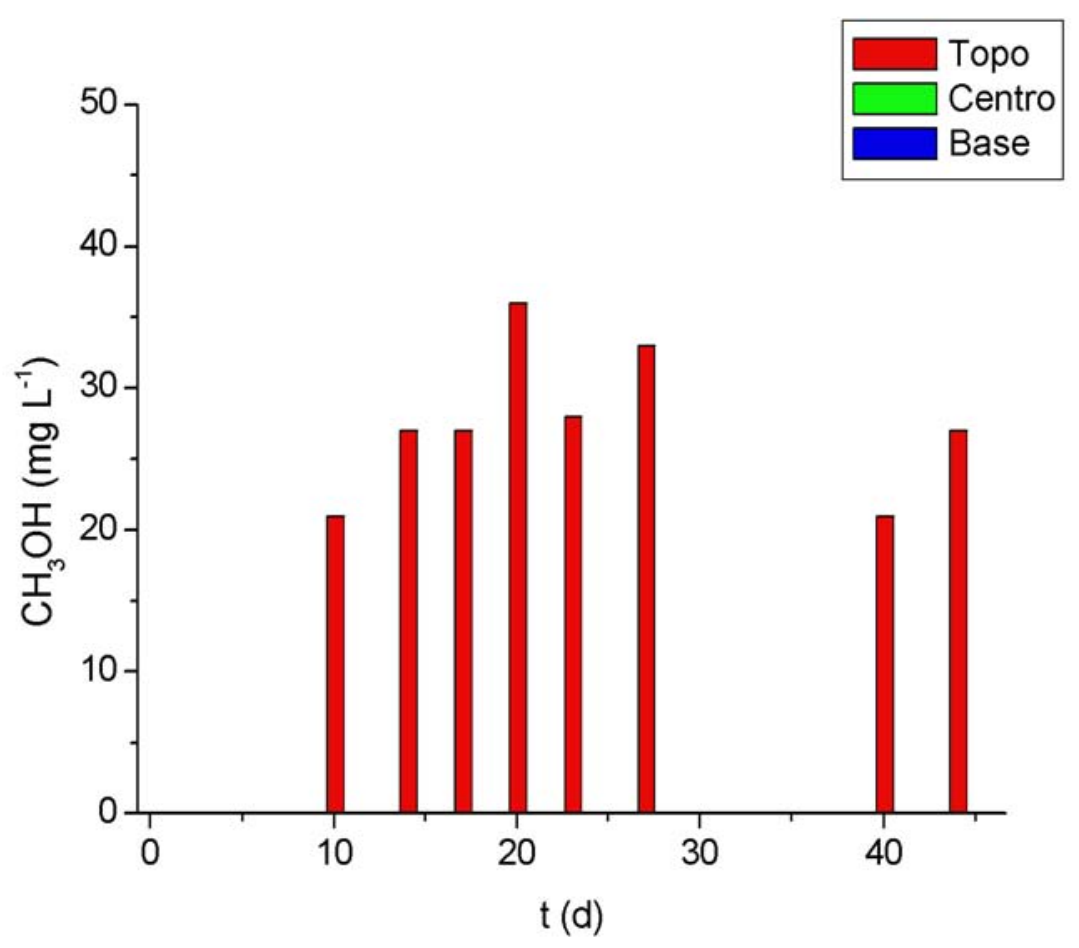

Figura 30: Valores de concentração espaço-temporal de metanol na sub-condição 2.2

A detecção do metanol ocorreu somente durante a sub-condição 2.2 , por um curto período de tempo e de maneira inconstante. Nas sub-condições 2.1 e 2.3, este composto não foi detectado. Algumas hipóteses foram levantadas para explicar esse fenômeno:

a) Longo start-up específico dos microrganismos associados à produção de metanol

Uma explicação possível é o provável longo tempo necessário para a adaptação da comunidade microbiana às condições ambientais (start-up específico para a conversão do metano a metanol). Ressalta-se que o referido composto orgânico não foi detectado na subcondição anterior (2.1), vindo a ser detectado somente durante a sub-condição 2.2. Portanto, algum tempo depois do início da inserção do biogás contendo metano na câmara anóxica. 


\section{b) Baixa solubilidade do metano}

Outro fator que poderia ter dificultado a produção do metanol é, certamente, a baixa solubilidade do substrato necessário (metano). De acordo com a Lei de Henry, a solubilidade do metano nas CNTP em água é muito baixa $\left(\sim 26 \mathrm{mg} \mathrm{L}^{-1}\right)$. Todavia, acredita-se que nas condições experimentais avaliadas, a solubilização deste composto possa ter sido favorecida, uma vez que a condição de operação foi do tipo contra-corrente entre a fase gasosa (fluxo ascendente) e a líquida (fluxo descendente). Ademais, acredita-se que a pressão exercida pela coluna do líquido, no ponto de injeção do biogás, possa ter auxiliado, de alguma maneira, a dissolução do composto gasoso na fase líquida. Ademais, as eficiências consideráveis de remoção do metano praticamente descartam essa possibilidade.

c) Elevadas velocidades de consumo de metanol

Finalmente, uma das hipóteses levantadas é a de que o metanol pode, de fato, ter sido constantemente produzido. O perfil espacial de produção de metanol mostra que este composto não foi detectado em outras seções de amostragem, portanto é possível que ele tenha sido utilizado pelos microrganismos desnitrificantes na mesma região onde foi disponibilizado pelas bactérias metanotróficas. Também é importante salientar que o limite de detecção do método aplicado ao monitoramento do metanol é de $6 \mathrm{~m} \mathrm{~L}^{-1}$.

De maneira análoga ao ocorrido com o doador sulfeto de hidrogênio, salienta-se que a câmara aeróbia provavelmente serviu para "polir" o metano remanescente oriundo da câmara anóxica. A reação biológica geral que descreve o processo de oxidação aeróbia do metano ocorrido na câmara aeróbia está representada na Equação 31 (Hanson e Hanson, 1996): 


$$
\mathrm{CH}_{4}+2 \mathrm{O}_{2} \rightarrow \mathrm{CO}_{2}+2 \mathrm{H}_{2} \mathrm{O}
$$

Equação 31

\subsubsection{Microrganismos: acompanhamento das morfologias}

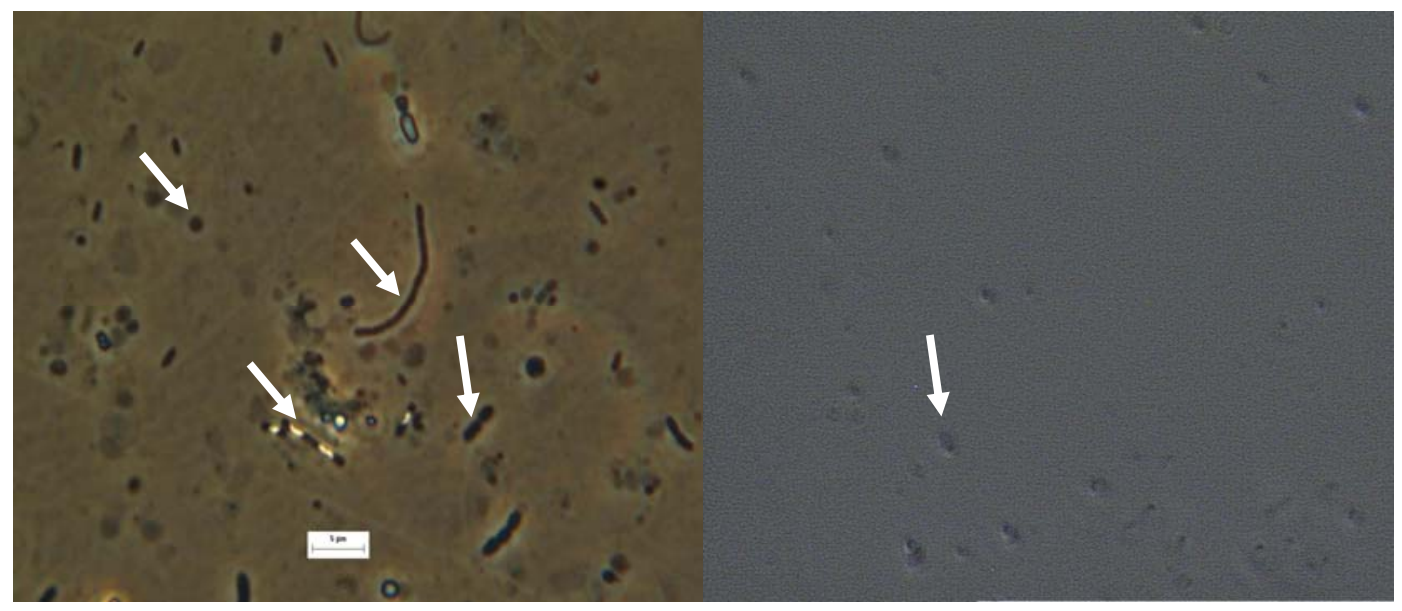

(a1)

(b1)

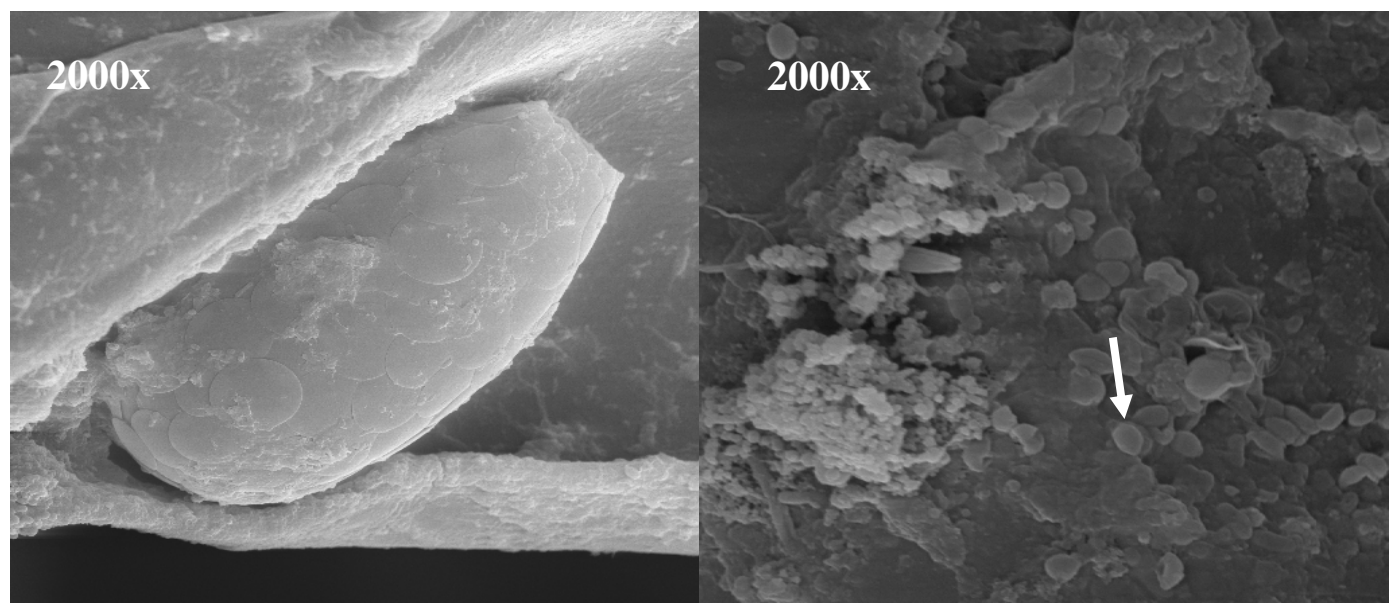

(a2)

Figura 31: Amostras retiradas do topo (a) e da base (b) da câmara aeróbia - Condição 2.

(a1) Células livres - bacilos e cocos e (a2) Protozoário; (b1) Cocos semelhante a Nitrosococcus e (b2) Células livres - bacilos e cocos

Nesta etapa foi possível observar a predominância de bacilos (Figura 32a1), cocos (Figura 32 a1,a2 e b2) e protozoários (Figura 32a2) nas amostras retiradas da câmara aeróbia. Na base da câmara (Figura 32b1) é possível verificar morfologias semelhantes à Nitrosococcus. Também é possível 
112

verificar a existência de microrganismos com pontos luminosos no seu interior (Figura 32a1), o que pode indicar a ocorrência da oxidação de formas reduzidas de enxofre à formas mais oxidadas, como enxofre elementar, por microrganismos autotróficos oxidadores de sulfeto, como os da espécie Thiobacillus thioparus.

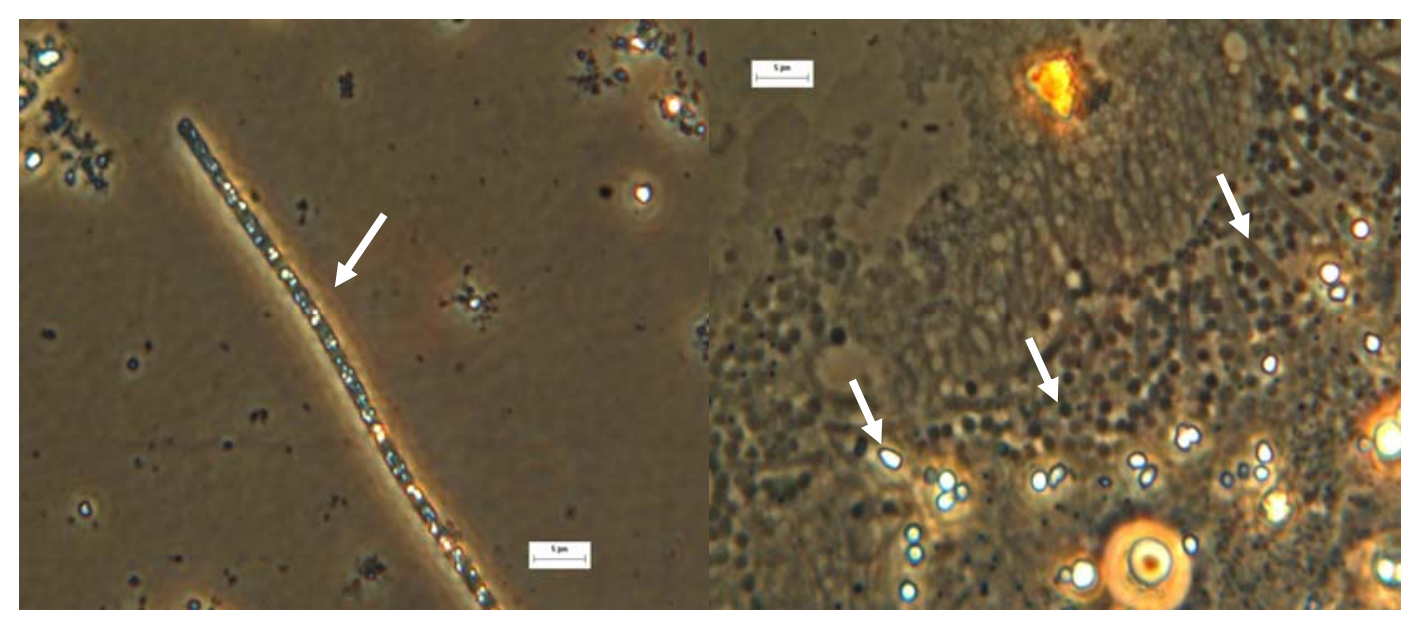

(a1)

(b1)

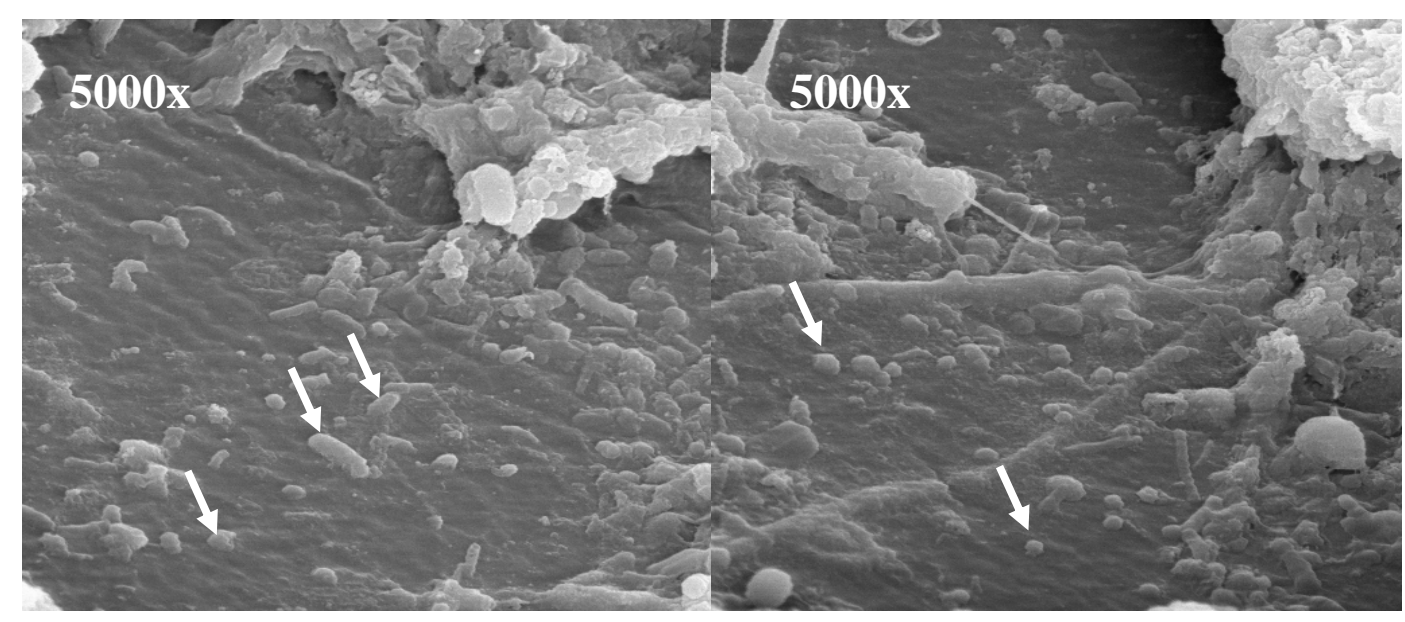

(a2)

(b2)

Figura 32: Amostras retiradas do topo (a) e da base (b) da câmara anóxica - Condição 2.

a1: morfologia similar a Beggiatoa; b1: pontos luminosos, agrupamento de cocos, e bacilos; a2:

bacilos e cocos; b2: bacilos e cocos

Nestas condições, segundo a literatura e os resultados obtidos anteriormente, a oxidação do sulfeto pelos microrganismos desnitrificantes autotróficos pode ser parcial, gerando intermediários como enxofre elementar. Os grânulos de enxofre elementar apareceram nas microscopias como pontos 
luminosos próximos a agrupamentos de bacilos, pois foram encontrados muitos aglomerados com coloração dourada (Figura 32b1). Também é possível visualizar cocos e poucos filamentos. As imagens de MEV tanto do topo quanto da base indicam a presença de bacilos - indicativo de morfologia semelhante a Thiobacillus denitrificans e também a presença de algumas formas indicativas de enxofre elementar, como do gênero Beggiatoa (Figura 32a1), que são oxidadoras de formas mais reduzidas de enxofre.

Nesta condição houve a produção de metanol a partir da oxidação parcial do metano na região do topo da câmara anóxica. Das amostras extraídas desta região (Figura 32a2,b1) é possível verificar tanto a presença de morfologias semelhantes à de bactérias metanotróficas, principalmente cocos e cistos e bastões curtos usualmente individuais (típicos de organismos metanotróficos do tipo 1 e do tipo 2) . De acordo com Visscher e Cleemput (2003), os organismos metanotróficos do Tipo 1 (Methylomonas sp., Methylobacter sp. e Methylococcus sp.) possuem maior velocidade de crescimento em ambiente onde o nitrogênio inorgânico, como por exemplo, o nitrato, não é limitante, enquanto que, na presença de nitrogênio amoniacal os organismos do Tipo 2 (Methylocystis sp. e Methylosinus sp.) são favorecidos.

A análise do número mais provável (item 5.6.1 Número mais provável) indicou que, embora em menor número, ordens de grandeza de pelo menos 5 graus de magnitude inferior à concentração de microrganismos desnitrificantes, foi possível detectar microrganismos metanotróficos na referida câmara, suportando a hipótese da ocorrência da desnitrificação associada à oxidação do metano na câmara anóxica. Como pode se observado, as espumas se encontravam bem colonizadas, a utilização deste meio suporte se mostrou eficiente para a adesão dos microrganismos nas condições estudadas, fato que reflletiu na análise do número mais provável. 


\subsubsection{ANÁLISE DA CONDIÇÃO 3}

Nesta condição, o reator foi submetido ao $\theta$ h ótimo verificado na etapa anterior ( 5 horas) e a uma drástica diminuição na concentração de sulfeto de hidrogênio aplicada, a qual foi reduzido para os níveis comumente encontrados em efluentes gasosos oriundos de reatores anaeróbios tratando esgoto sanitário.

\subsubsection{Dinâmica de remoção da matéria orgânica carbonácea}

No gráfico da Figura 33, pode-se observar que a $\mathrm{DQO}_{\text {total }}$ afluente oscilou significativamente, com valores variando entre 40 e $187 \mathrm{mg} \mathrm{L}^{-1}$. Entretanto, mesmo com esta variação e os picos verificados, o RAALF mostrou grande capacidade em absorver as oscilações de concentração de matéria orgânica às quais foi submetido.

A eficiência de remoção média da matéria orgânica foi de 93,4\%. Portanto, o RAALF mostrou rápida capacidade de recuperação com o aumento do $\theta$ h de 2,5 horas para 5 horas.

Os resultados dos perfis espaciais longitudinais (Figura 34) indicaram que, já no primeiro ponto de tomada de amostras, mais de $74 \%$ da matéria orgânica já havia sido removida. Ou seja, entre L/D = 0 e L/D $\sim 0,8$, ocorreu a maior atividade do grupo de microrganismos responsáveis pela remoção da matéria orgânica carbonácea, tal qual ocorreu durante a sub-etapa 2.2 da etapa anterior, embora em percentuais inferiores se comparados a esta etapa. 


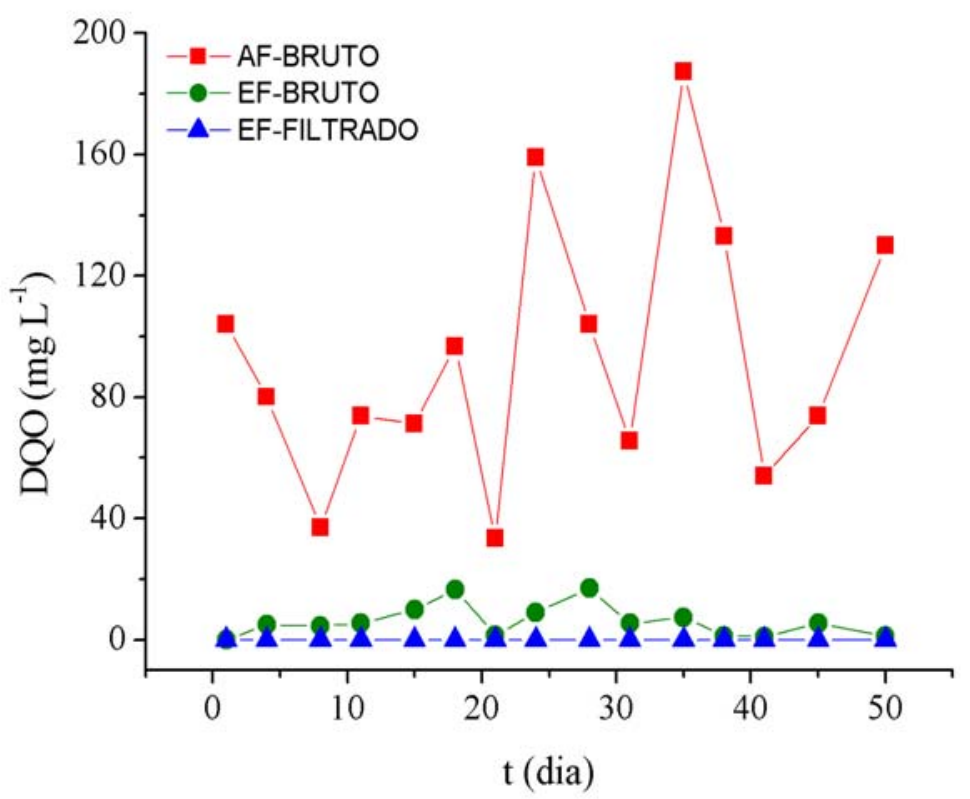

Figura 33: Dinâmica da $\mathrm{DQO}_{\text {total }}$ - Condição 3

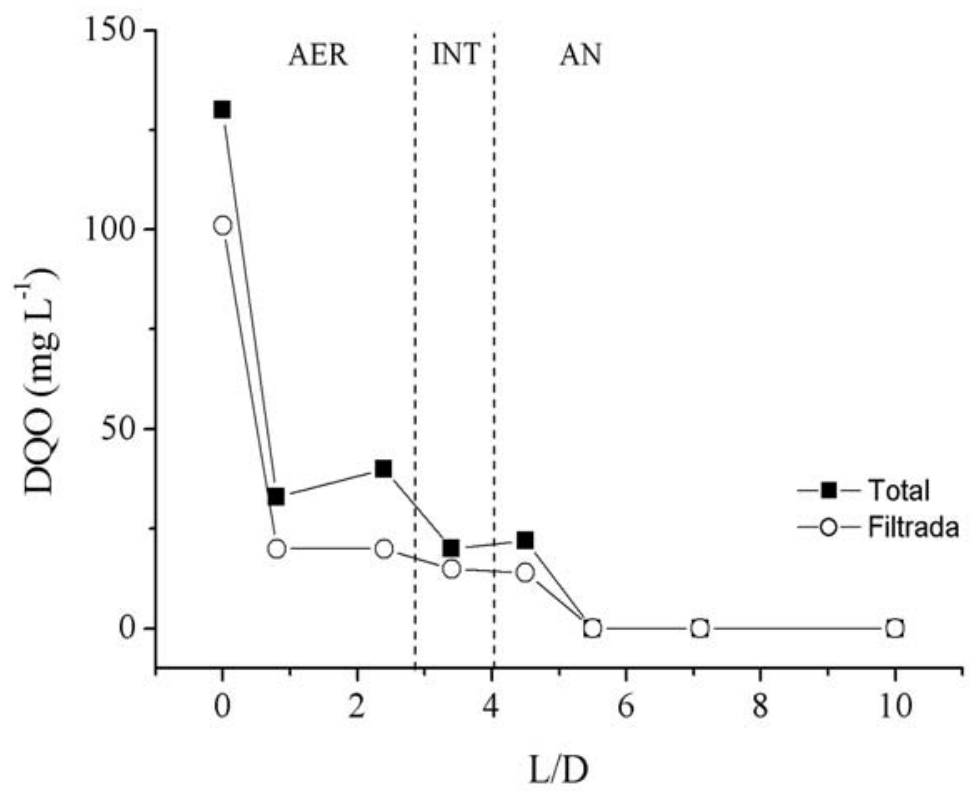

Figura 34: Perfil espacial de DQO - Condição 3 


\subsubsection{Dinâmica das formas nitrogenadas}

A concentração média de $\mathrm{N}-\mathrm{NH}_{4}{ }^{+}$afluente à câmara aeróbia foi de $32,6 \pm 1,8 \mathrm{mg} \mathrm{L}^{-1}$, enquanto

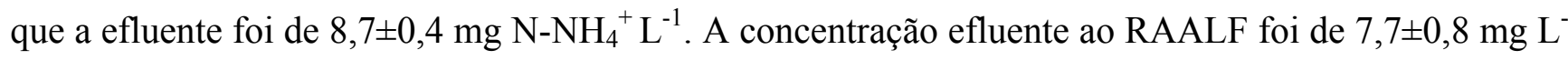
1 , indicando que não houve consumo de nitrogênio amoniacal na câmara desnitrificante, conforme pode ser observado no gráfico da Figura 35.

A eficiência de remoção do nitrogênio amoniacal, nesta condição, foi de $73,4 \%$. Uma comparação entre a eficiência de remoção nesta condição e na sub-condição 2.2 da condição 2 revela que o desempenho da câmara aeróbia não foi o mesmo, já que a eficiência de oxidação foi de $83,3 \%$ na sub-condição citada. Ou seja, ao contrário do grupo de microrganismos heterotróficos responsáveis pela remoção da matéria orgânica carbonácea, que conseguiu plena reabilitação após o aumento do $\theta$ h, o grupo de bactérias oxidantes de nitrogênio amoniacal não conseguiu restabelecer o comportamento observado na sub-condição supracitada.

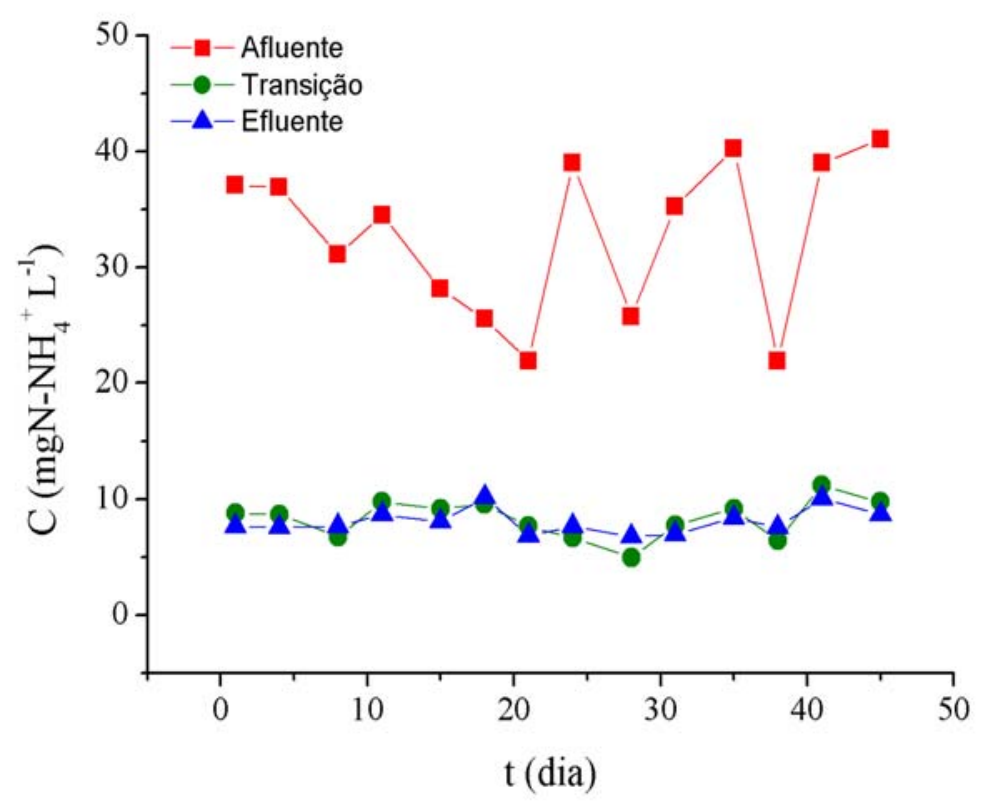

Figura 35: Dinâmica do $\mathrm{N}_{-} \mathrm{NH}_{4}^{+}$- Condição 3 
O desempenho inferior da remoção de nitrogênio amoniacal verificado nesta etapa foi uma das variáveis que afetou a produção do receptor de elétron final para a desnitrificação, o nitrato. O gráfico da Figura 36 mostra que os níveis de nitrato foram mais elevados em comparação com a sub-condição $2.3(\theta h=2,5 h)$, mas foram inferiores aos detectados durante a sub-condição $2.2(\theta h=5 h)$.

A média da concentração de nitrato no efluente da câmara aeróbia foi de $16,6 \pm 1,3 \mathrm{mg} \mathrm{L}^{-1}$, enquanto a média efluente ao RAALF foi de $7,1 \pm 0,1 \mathrm{mg} \mathrm{L}^{-1}$. Além de ter ocorrido a diminuição da produção de nitrato na câmara aeróbia, a queda do desempenho da desnitrificação, verificada nesta etapa, deve-se também ao fato de o sulfeto, que foi o doador de elétrons preferencial para a desnitrificação na condição anterior, estar em concentração muito inferior (concentração traço) àquela aplicada na condição 2 (Figura 36).

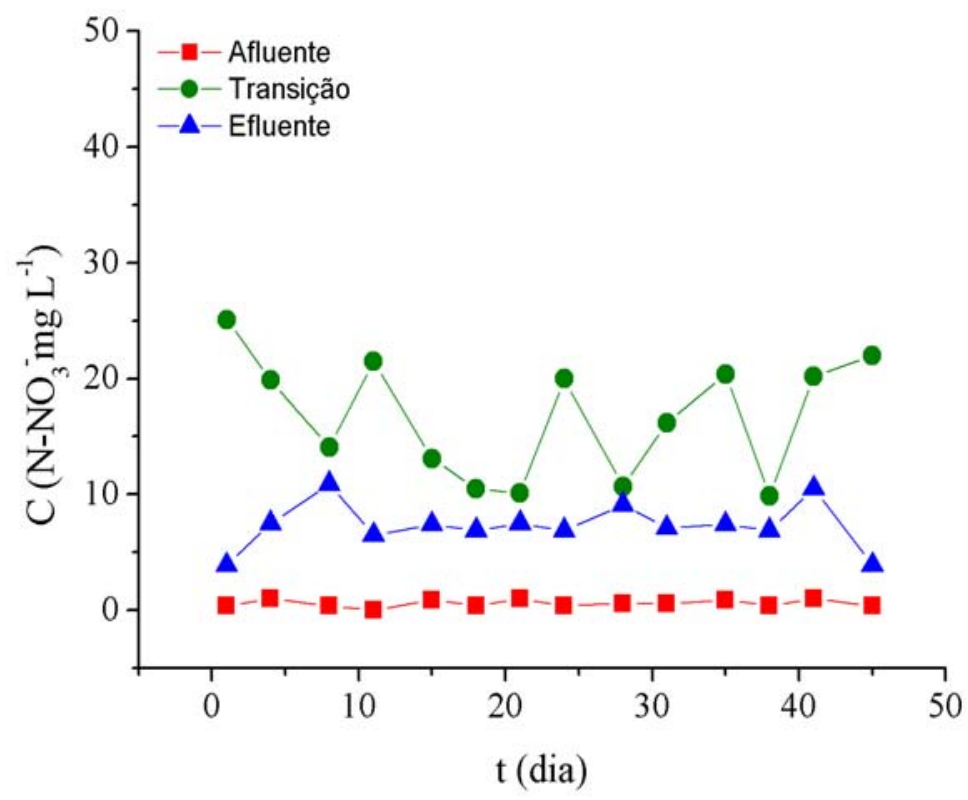

Figura 36: Dinâmica do nitrato - Condição 3 


\subsubsection{Oxigênio dissolvido e potencial redox}

Os perfis espaciais de oxigênio dissolvido (Figura 37), realizados durante esta condição, revelaram que o reator manteve as mesmas condições verificadas durante a etapa 2, ou seja, era composto por um estrato aeróbio - câmara aeróbia (com OD sempre superior a $2 \mathrm{mg} \mathrm{L}^{-1}$ ), um estrato aerofílico - câmara anóxica (com OD oscilando entre 0,5 e $1 \mathrm{mg} \mathrm{L}^{-1}$ ) e um estrato efetivamente

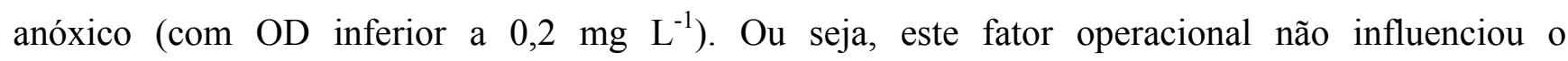
comportamento do RAALF nesta etapa no sentido de impedir a ocorrência dos processos biológicos de interesse.

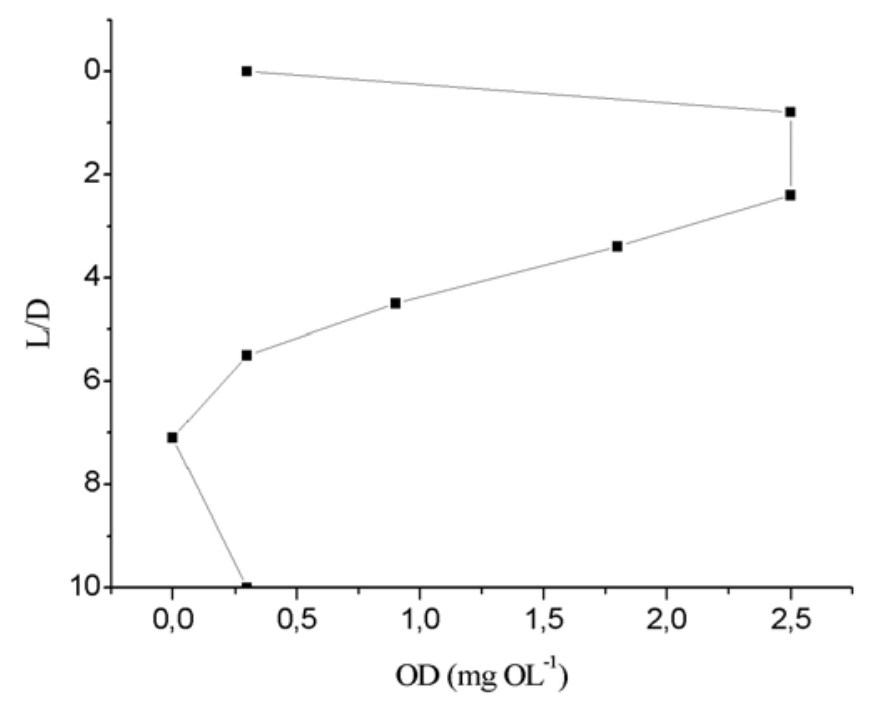

Figura 37: Perfil espacial de OD - Condição 3

Aer: câmara aeróbia; Int: câmara intermediária; An: câmara anóxica

Analogamente ao observado na condição 2, o perfil do potencial redox revelou que este acompanhou o perfil de oxigênio dissolvido. Os valores oscilaram de levemente positivos na câmara aeróbia para altamente negativos na câmara anóxica, especialmente nas seções inferiores desta (Figura 38). 


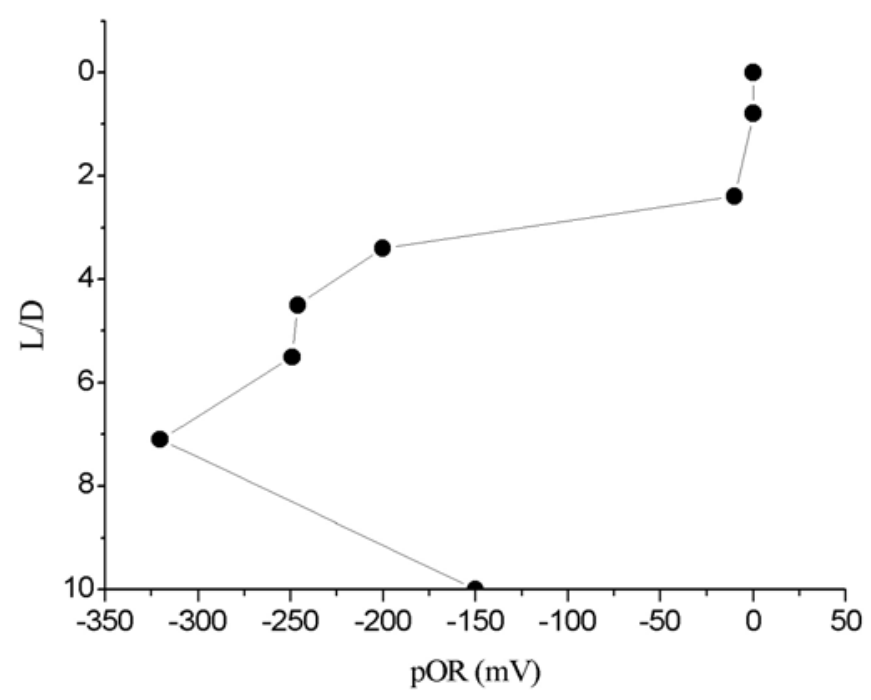

Figura 38: Perfil espacial do potencial de óxido-redução (pOR) - Condição 3

Aer: câmara aeróbia; Int: câmara intermediária; An: câmara anóxica

\subsubsection{Comportamento do pH e alcalinidade}

Durante esta condição, a fonte externa de alcalinidade continuou sendo adicionada com vistas a elevar os valores de $\mathrm{pH}$, especialmente devido à inserção de dióxido de carbono na massa líquida e sua possível conversão para ácido carbônico. Um resumo estatístico está apresentado na Tabela 16:

O RAALF se mostrou altamente estável com vistas às dinâmicas de $\mathrm{pH}$ e alcalinidade com a utilização do alcalinizante externo. Condições ligeiramente básicas puderam ser verificadas ao longo do reator, em faixa que não impedia a ocorrência de todos os processos bioquímicos de interesse.

Tendo em vista que as várias possibilidades de desnitrificação nesta câmara, a produçãoconsumo de alcalinidade bem como as variações de $\mathrm{pH}$ tornam-se processos extremamente dinâmicos e complexos de serem avaliados. 
Tabela 16: Comportamento médio do pH e da alcalinidade - Condição 3

\begin{tabular}{|c|c|c|c|}
\hline \multirow[t]{2}{*}{ Ponto } & \multicolumn{3}{|c|}{ pH (unidades) } \\
\hline & Mín & Máx & $\mathrm{M}$ \\
\hline Afluente & 5,7 & 7,7 & $7,0 \pm 0,3$ \\
\hline Intermediário & 6,5 & 7,6 & $7,9 \pm 0,4$ \\
\hline Efluente & 6,8 & 7,5 & $7,3 \pm 0,4$ \\
\hline \multicolumn{4}{|c|}{ Alcalinidade Total $\left(\mathrm{mg} \mathrm{CaCO}_{3} \mathrm{~L}^{-1}\right)$} \\
\hline & Mín & Máx & M \\
\hline Afluente & 150 & 255 & $168 \pm 20$ \\
\hline Intermediário & 155 & 201 & $160 \pm 37$ \\
\hline Efluente & 107 & 160 & $177 \pm 21$ \\
\hline
\end{tabular}

\subsubsection{Dinâmica da desnitrificação com biogás}

A diminuição da concentração do doador de elétrons sulfeto de hidrogênio no biogás, de $50 \mathrm{~g}$ $\mathrm{m}^{-3}$ para $0,5 \mathrm{~g} \mathrm{~m}^{-3}$, teve reflexo na concentração de sulfato na câmara desnitrificante. De maneira análoga ao ocorrido nos perfis realizados durante a 2 , a variação da concentração de sulfato, ao longo do RAALF, apresentou valores crescentes da entrada até a saída (ponto de injeção do biogás) do efluente do reator, conforme pode se observado no gráfico da Figura 39.

Nesta etapa, a média de sulfato afluente ao RAALF foi de $20,1 \pm 9,9 \mathrm{mg} \mathrm{L}^{-1}$, na câmara anóxica foi de $29,9 \pm 5,7 \mathrm{mg} \mathrm{L}^{-1}$, e no efluente do reator foi de $35,5 \pm 7,7 \mathrm{mg} \mathrm{L}^{-1}$. Ensaios de atividade desnitrificante (item 5.2.6), realizados com amostras retiradas da câmara anóxica do RAALF para a verificação do doador de elétrons preferencial nesta etapa do trabalho, evidenciam a queda da utilização do sulfeto como doador de elétrons. 


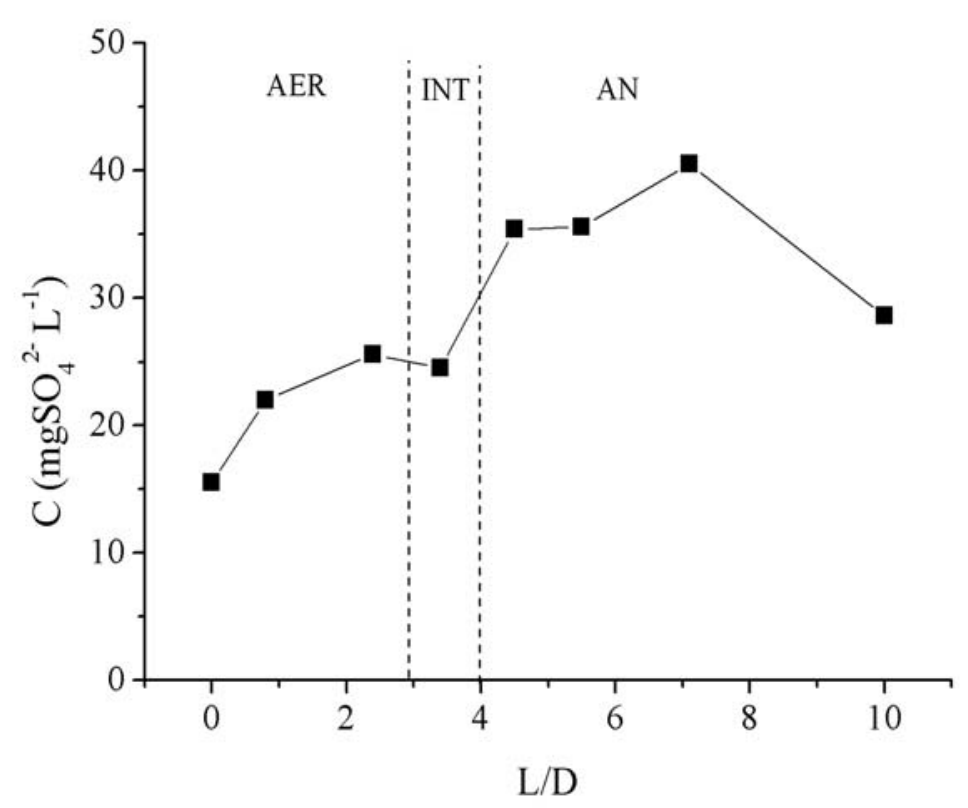

Figura 39: Perfil espacial de concentração de sulfato (Condição 3)

Nesta condição, nenhum produto intermediário originário de possível oxidação parcial do metano foi detectado. Todavia, levando-se em consideração a discussão reportada no item 5.2.2.5: dinâmica da desnitrificação pode ser que o mesmo tenha sido produzido pelos organismos metanotróficos, mas prontamente consumido pelos organismos desnitrificantes. A carência de doador de elétron sulfuroso, no estrato efetivamente anóxico, pode ter proporcionado um ambiente menos competitivo, fazendo com que os microrganismos tenham atuado no sentido de prover a desnitrificação heterotrófica. Diante de uma condição de carência de doadores de elétrons, é possível que a velocidade de reação proporcionada pelos microrganismos desnitrificantes do consórcio mixotrófico tenha sido maior, dificultando a detecção de compostos intermediários possivelmente produzidos.

Além do mais, pode ser que o metano tenha sido utilizado diretamente como doador de elétrons para a desnitrificação na câmara desnitrificante, por um outro grupo de microrganismos. Esta hipótese foi testada por meio de ensaios de atividade desnitrificante realizados com amostras retiradas da câmara anóxica, submetidos aos doadores de elétrons encontrados no RAALF. Os ensaios revelaram que a atividade dos microrganismos metanotróficos praticamente dobrou, passando de 0,17 para 0,26 gN.(gSVT.d) ${ }^{-1}$. Soma-se a isso o aumento em uma ordem de grandeza da concentração de organismos 
metanotróficos na câmara anóxica, em comparação com a condição 2, tendo como base os ensaios de número mais provável realizados (item 5.6.1: Número Mais Provável)

\subsubsection{Microrganismos: acompanhamento das morfologias}

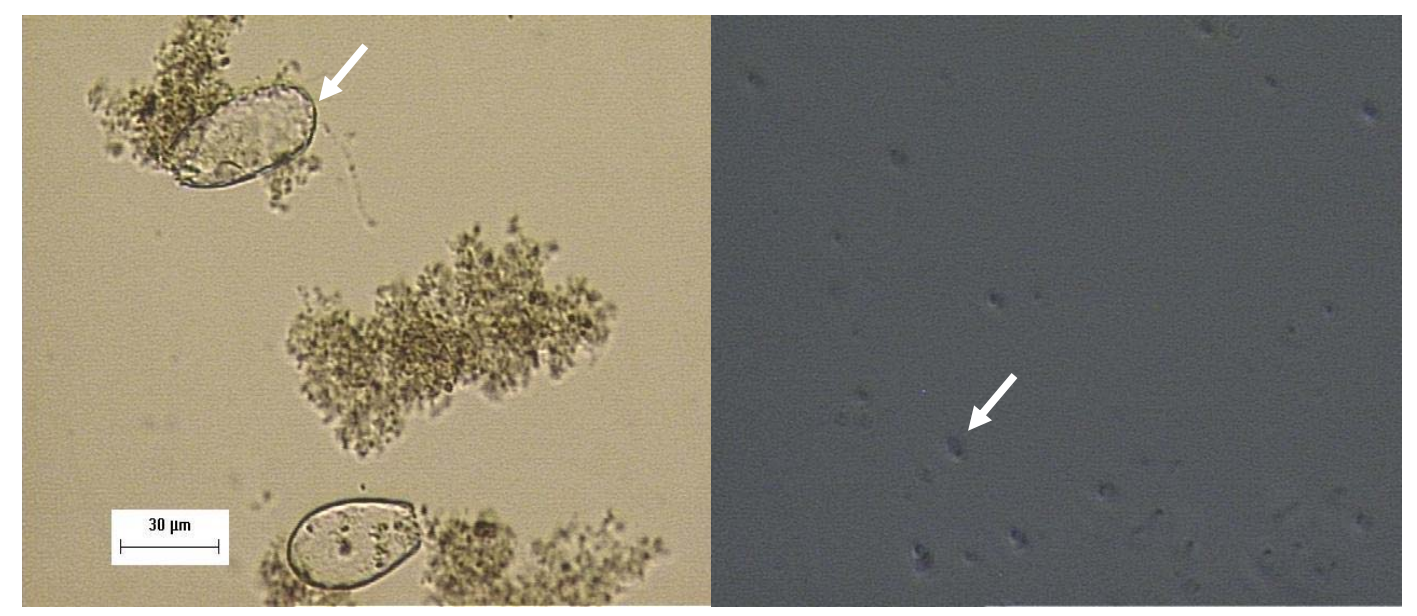

(a1)

(b1)

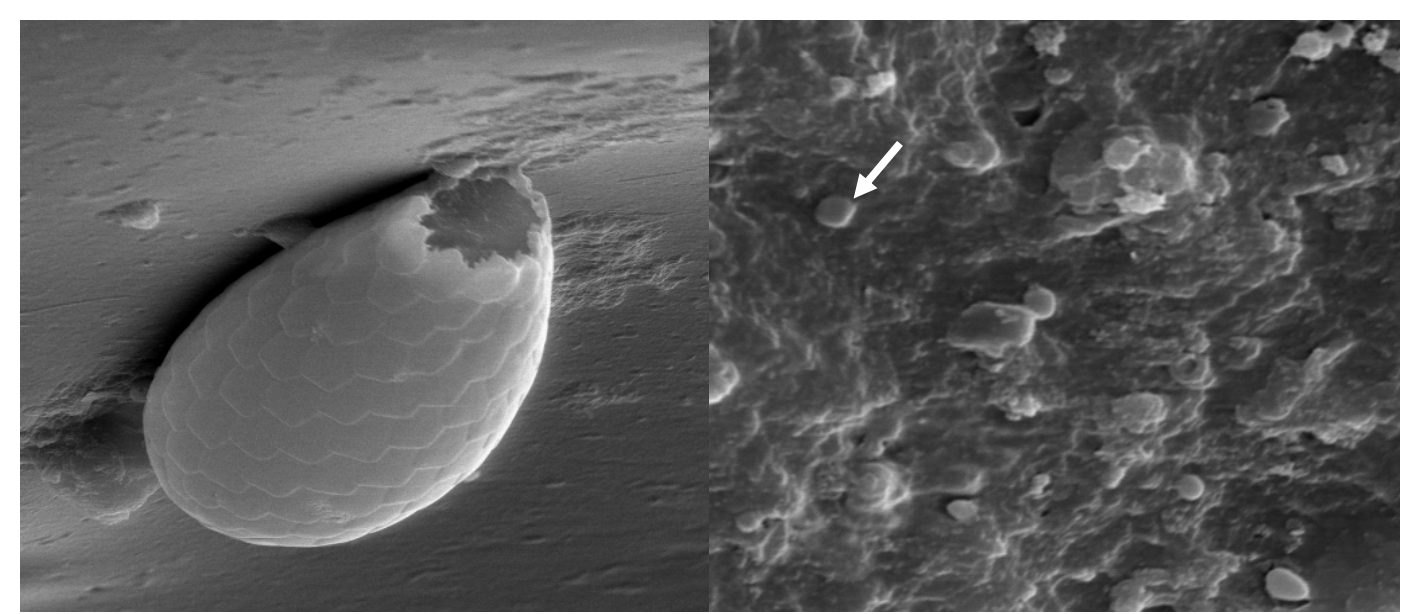

(a2)

(b2)

Figura 40: Morfologias observadas a partir de amostras retiradas do topo (a) e da base (b) da câmara aeróbia - Condição 3.

(a1 e a2) protozoário e rotiferos; (b1) cocos semelhante a Nitrosococcus 
Com auxílio das imagens de microscopia ótica (Figura 40) é possível observar que os microrganismos do compartimento aeróbio representavam razoavelmente bem um ambiente aeróbio, apresentando diversidade de bactérias, protozoários, com morfologias como bacilos pequenos, cocos nitrificantes e bacilos.

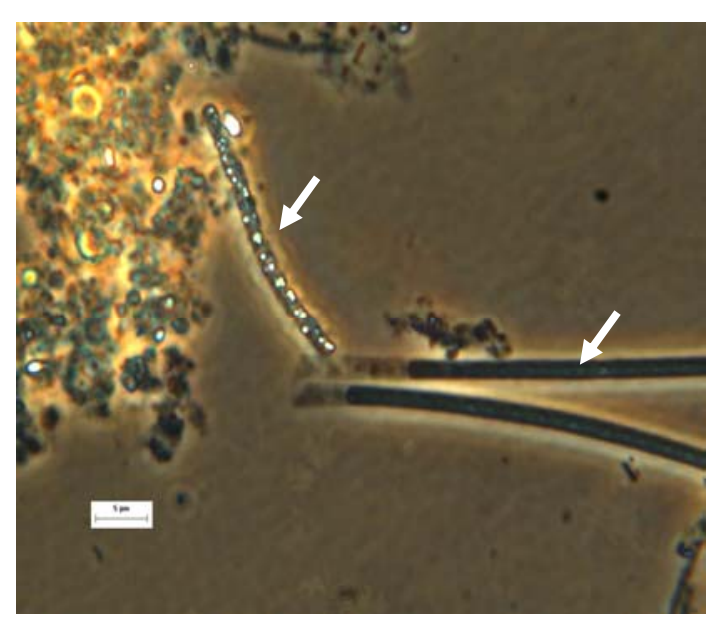

(a1)

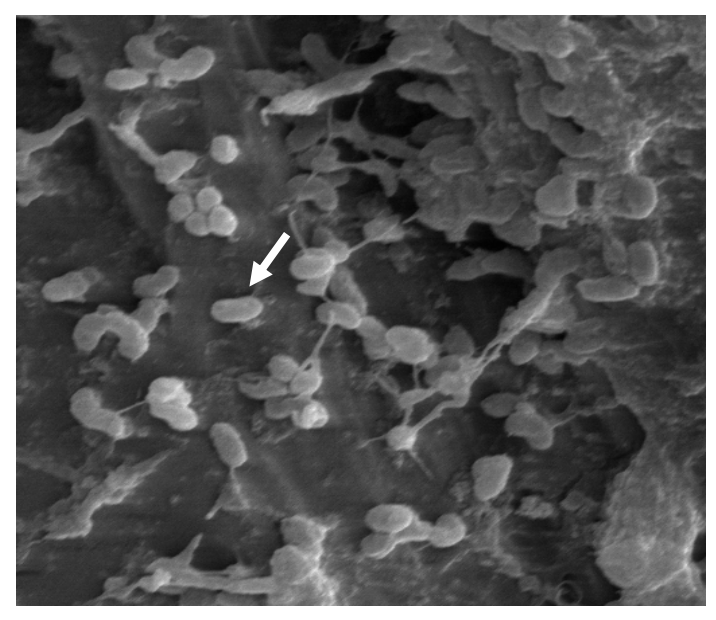

(a2)

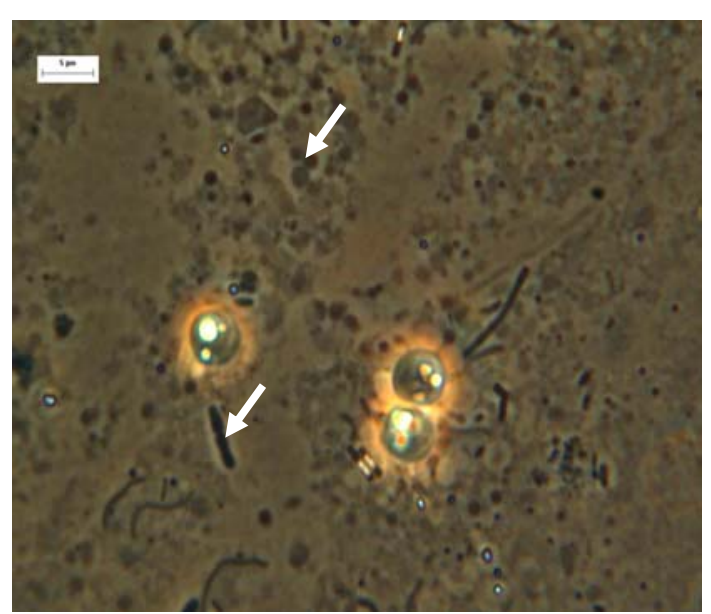

(b1)

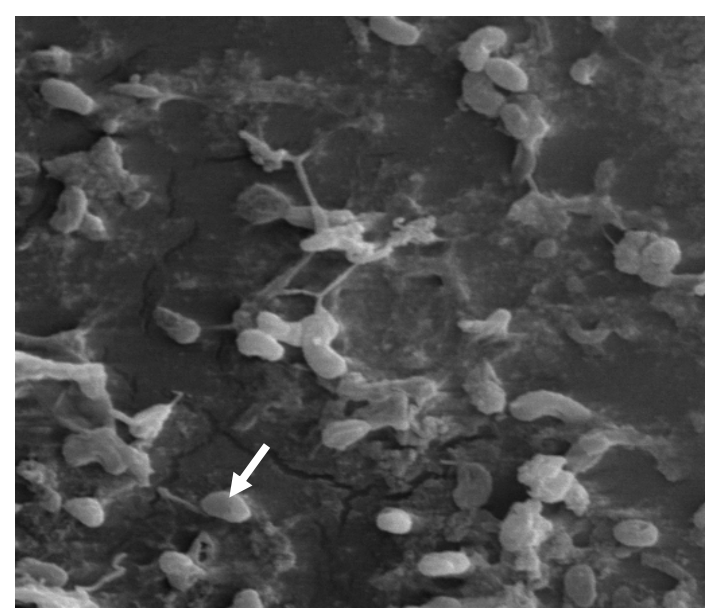

(b2)

Figura 41: Amostras retiradas do topo e da base da câmara anóxica - Condição 3.

(a1) Morfologias semelhantes à Beggiatoa e Thiotrix, (b1) células livres - cocos e bacilos; (a2 e b2) predominância de bacilos e alguns cocos.

Na condição 3, mesmo com a redução da concentração de sulfeto de hidrogênio aplicada ainda é possível verificar morfologias semelhantes à Thiotrix assim como na fase anterior, na qual o sulfeto 
foi aplicado em maior concentração, o que indica a contínua atividades desses organismos mesmo com a reduzida concentração do doador de elétrons sulfuroso.

Nesta condição não houve detecção do metanol. Todavia, a análise do número mais provável para os organismos metanotróficos apontou para o incremento em uma ordem de magnitude da concentração destes na câmara anóxica, indicando que o metano de fato poderia estar sendo convertido nesta câmara.

A partir das imagens de microscopia eletrônica de varredura verifica-se a maior predominância de bacilos tanto no topo quanto na base da câmara anóxica em relação a condição 2. Como pode se observado, as espumas se encontravam bem colonizadas, a utilização deste meio suporte se mostrou eficiente para a adesão dos microrganismos nas condições estudadas, fato que reflletiu na análise do número mais provável.

\subsection{TAXA DE DESNITRIFICAÇÃO}

O comportamento da taxa de desnitrificação, durante a condição 2 (sub-condições 2.1 a 2.3 ) e condição 3, estão apresentados nos gráficos da Figura 42 e Figura 43, respectivamente.

A média verificada durante a sub-condição $2.2\left(178 \pm 43 \mathrm{~g}-\mathrm{N} \mathrm{m}^{-3} \mathrm{dia}^{-1}\right)$ foi superior à verificada durante a sub-condição $2.1\left(134 \pm 22 \mathrm{~g}-\mathrm{N} \mathrm{m}^{-3}\right.$ dia $\left.^{-1}\right)$, pois o reator manteve desempenho similar no tocante à remoção de nitrogênio. Entretanto a vazão aplicada foi maior (diminuição do $\theta$ h de 7,5 para 5 horas), com aumento da velocidade superficial do fluido resultando em um possível incremento na transferência de massa. 


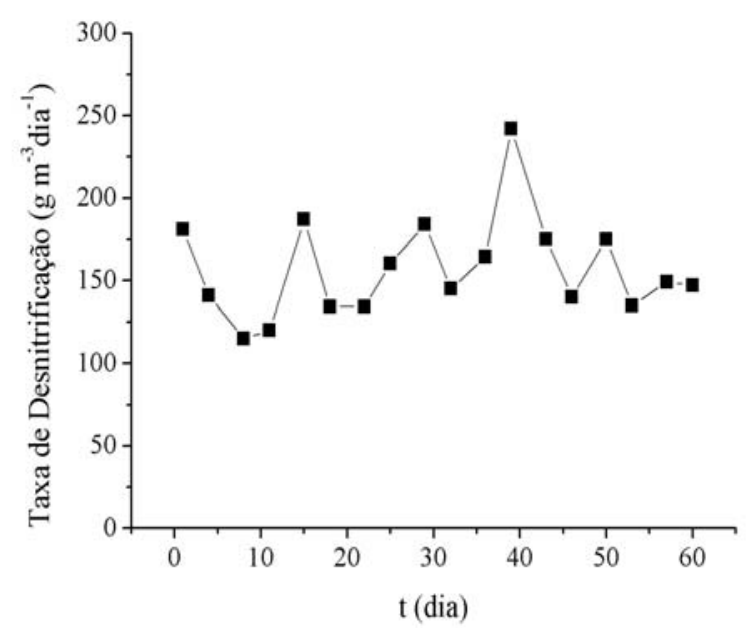

$\theta \mathrm{h}=7,5 \mathrm{~h}(\mathrm{a})$

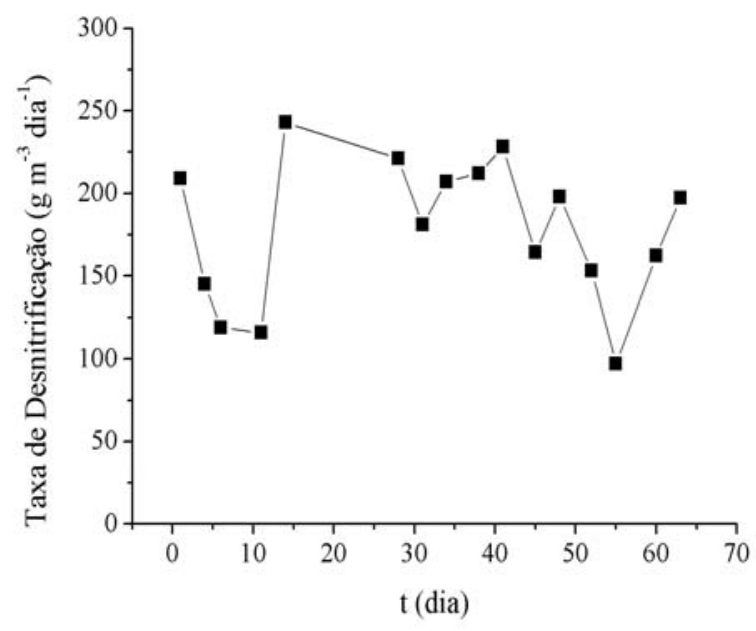

$\theta \mathrm{h}=5 \mathrm{~h}(\mathrm{a})$

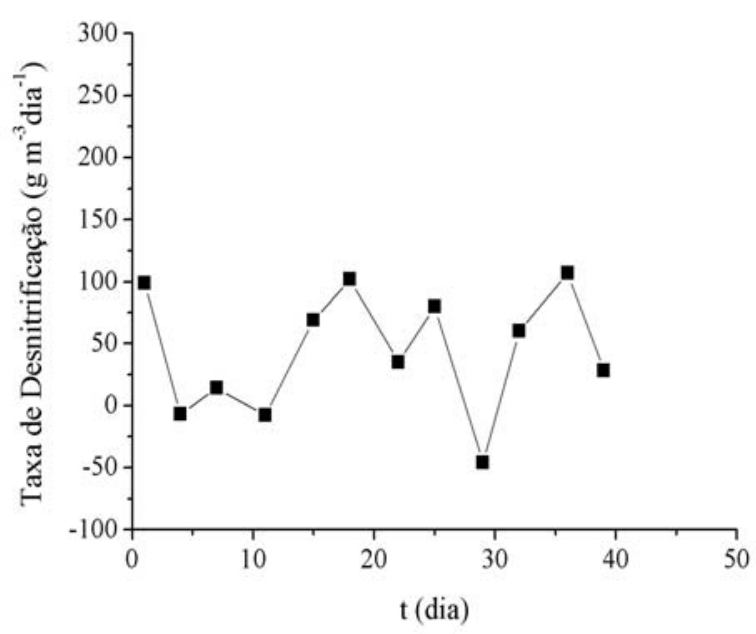

$$
\theta \mathrm{h}=2,5 \mathrm{~h}(\mathrm{a})
$$

Figura 42: Comportamento da taxa de desnitrificação - Condição 2 Sub-condição 1(a), sub-condição 2 (b) e sub-condição 3(c). 
126

Nota-se, também, queda acentuada e um desequilíbrio considerável nos valores da taxa de desnitrificação para níveis de $44 \pm 50 \mathrm{~g}-\mathrm{N} \mathrm{m}^{-3} \mathrm{dia}^{-1}$, durante a sub-condição 2.3 , resultado da queda de eficiência de oxidação do nitrogênio amoniacal à nitrato na câmara aeróbia.

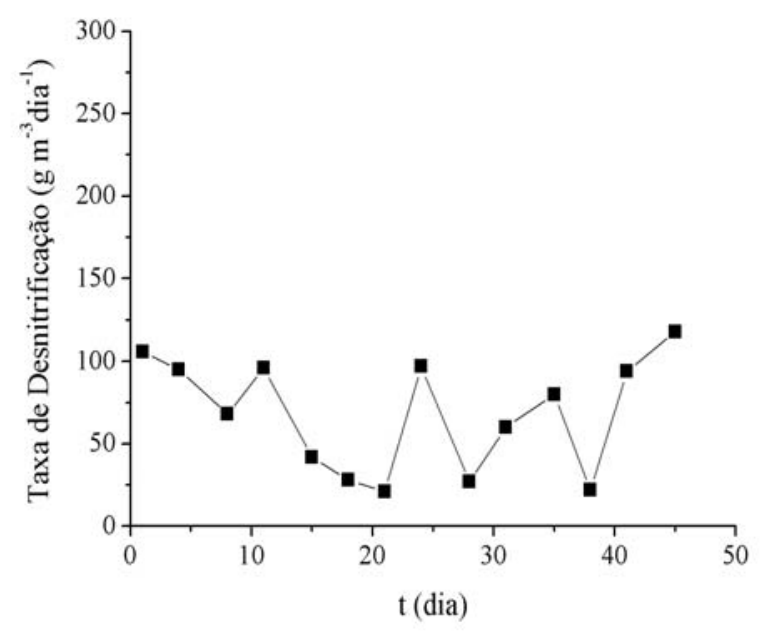

Figura 43: Comportamento da taxa de desnitrificação - Condição 3

Os valores negativos representam concentração de nitrato efluente maior que a efluente.

\subsection{REMOÇÃO DO BIOGÁS}

A eficiência de remoção de sulfeto de hidrogênio e de metano, no RAALF, está apresentada nos gráficos da Figura 44 e Figura 45, respectivamente. 


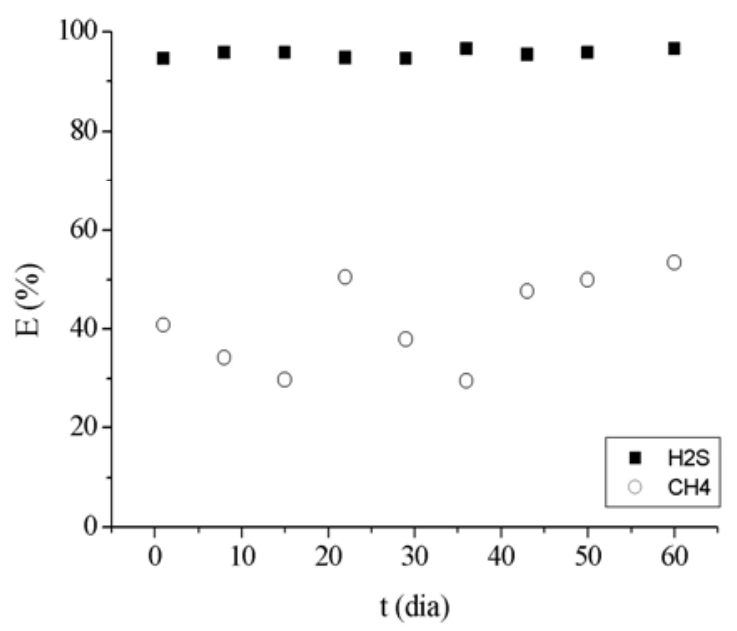

$\theta \mathrm{h}=7,5 \mathrm{~h}(\mathrm{a})$

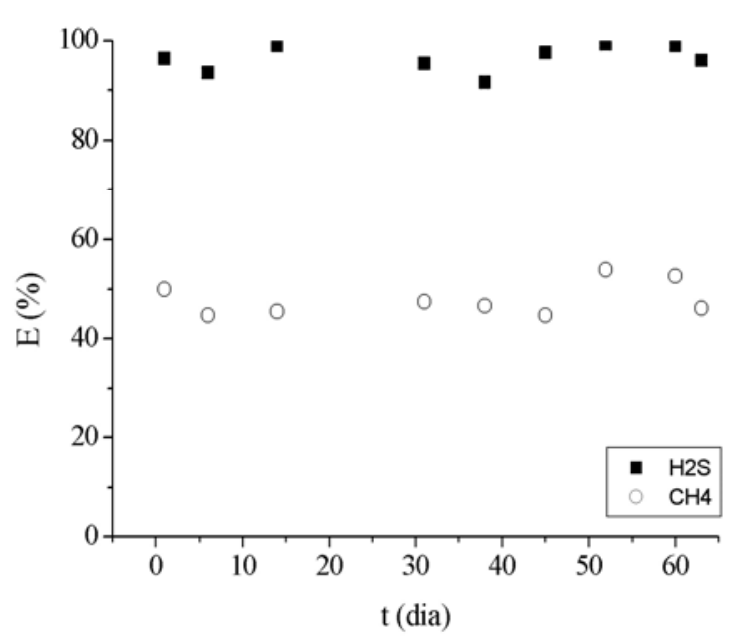

$\theta \mathrm{h}=5 \mathrm{~h}(\mathrm{a})$

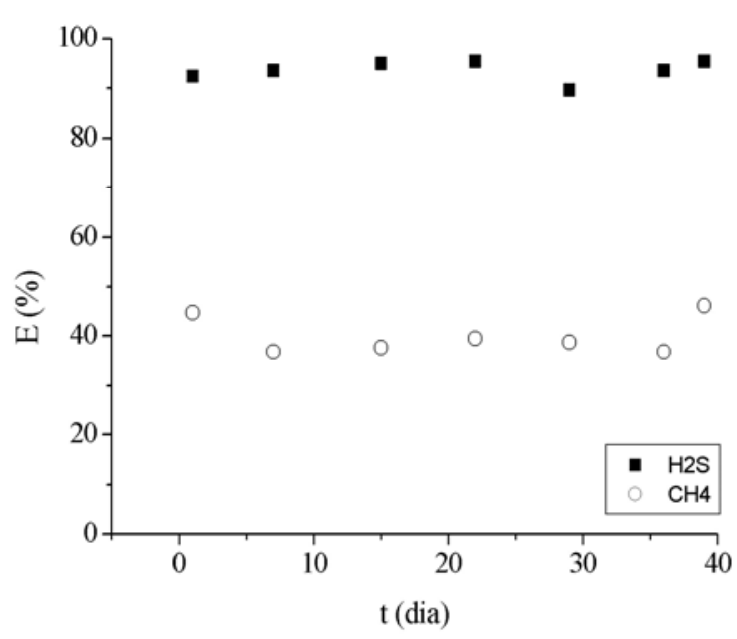

$\theta \mathrm{h}=2,5 \mathrm{~h}(\mathrm{a})$

Figura 44: Eficiência de remoção dos gases sulfeto de hidrogênio e metano - Condição 2 Sub-condição 1(a), sub-condição 2 (b) e sub-condição 3(c). 
Como durante a sub-condição 2.3, alguns processos, como a remoção de DQO e a remoção de nitrogênio amoniacal sofreram instabilidade na câmara aeróbia e também verificou-se a queda acentuada do processo de desnitrificação na câmara anóxica. A despeito destes fatos, a eficiência de remoção de sulfeto praticamente não se alterou. Pessupõe-se que a câmara aeróbia tenha atuado de maneira a polir o efluente gasoso oriundo da câmara anóxica (Figura 26). Nesse sentido, a comunidade oxidadora de sulfeto, presente na câmara aeróbia, mostrou-se eficiente e robusta.

Acredita-se que tal comportamento foi similar para a comunidade metanotrófica presente na câmara aeróbia do reator, pois, os valores de eficiência de conversão de metano foram altos, considerando a baixa solubilidade do composto, um dos fatores impeditivos para a sua degradação. Acredita-se que, à medida que o metano ascendeu ao longo do reator, sua solubilização tenha aumentado, o que pode ter facilitado o trabalho das metanotróficas que, diante das condições ambientais presentes na câmara Aeróbia (como alta disponibilidade de OD), converteram o metano a dióxido de carbono (Equação 31).

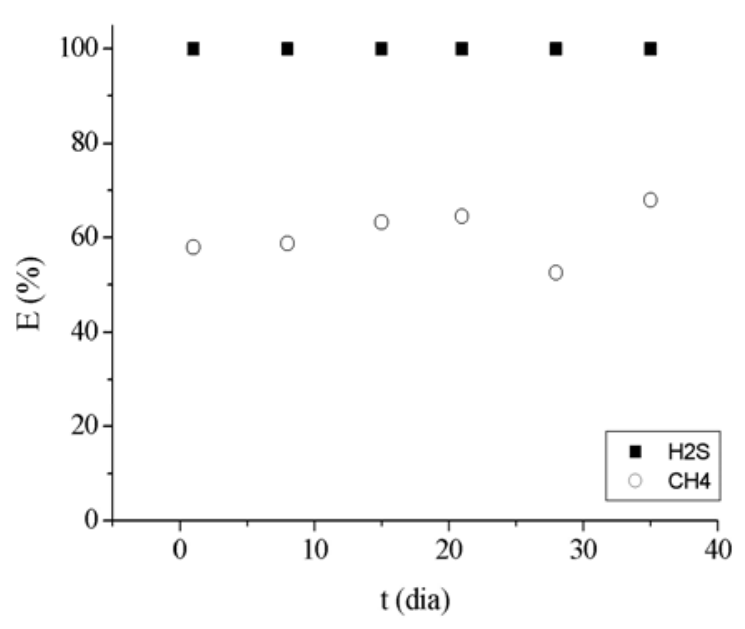

Figura 45: Eficiência de remoção dos gases sulfeto de hidrogênio e metano - Condição 3 
Durante a condição 3, a eficiência de remoção de sulfeto de hidrogênio manteve-se na casa dos 100\%. Houve, também, um incremento considerável nos valores de eficiência de remoção de metano para $61 \%$. Este aumento na eficiência de conversão de metano pode estar associado à sua maior utilização na câmara anóxica, o que é corroborado pelos dados de taxas de desnitrificação.

Os valores da concentração de entrada e saída, bem como a eficiência de remoção, durante as condições 2 e 3, estão apresentados na Tabela 17.

Tabela 17: Desempenho do RAALF enquanto sistema de tratamento de gases

\begin{tabular}{|c|c|c|c|c|c|}
\hline \multicolumn{2}{|c|}{ Condições } & Gases & $\begin{array}{l}\text { Entrada } \\
\left(\mathrm{g} \mathrm{m}^{-3}\right)\end{array}$ & $\begin{array}{l}\text { Saída } \\
\left(\mathrm{g} \mathrm{m}^{-3}\right)\end{array}$ & $\begin{array}{l}\text { ER } \\
(\%)\end{array}$ \\
\hline \multirow{6}{*}{2} & & $\mathrm{H}_{2} \mathrm{~S}$ & 50 & $2,2 \pm 0,4$ & 95,6 \\
\hline & & $\mathrm{CH}_{4}$ & 380 & $222,2 \pm 35,1$ & 41,5 \\
\hline & & $\mathrm{H}_{2} \mathrm{~S}$ & 50 & $1,8 \pm 1,3$ & 96,4 \\
\hline & 2.2 & $\mathrm{CH}_{4}$ & 380 & $197,8 \pm 13,1$ & 48,0 \\
\hline & & $\mathrm{H}_{2} \mathrm{~S}$ & 50 & $3,2 \pm 1,0$ & 93,6 \\
\hline & 2.3 & $\mathrm{CH}_{4}$ & 380 & $227,9 \pm 14,2$ & 40,0 \\
\hline \multirow{2}{*}{3} & & $\mathrm{H}_{2} \mathrm{~S}$ & 0,5 & 0 & 100,0 \\
\hline & $J$ & $\mathrm{CH}_{4}$ & 380 & $147,0 \pm 19,7$ & 61,3 \\
\hline
\end{tabular}

\subsection{BALANÇO MATERIAL DO NITROGÊNIO}

Na Figura 46 e na Figura 47, estão apresentados o balanço material de nitrogênio para a condição 2 (sub-condição 2.2) e condição 3 do trabalho, com vistas à desnitrificação. Por esse motivo, os dados de input e output de nitrogênio foram os da concentração dos compostos no setor de transição entre as câmaras aeróbia e anóxica, e efluente ao RAALF. 
Considerou-se que a concentração total de compostos nitrogenados na fase líquida era constituída por nitrogênio amoniacal, nitrito e nitrato afluente e efluente ao reator e que a fração de nitrogênio removida do sistema era constituída pelo nitrogênio orgânico associado (N-org) à biomassa e por nitrogênio gasoso $\left(\mathrm{N}-\mathrm{N}_{2}\right)$.

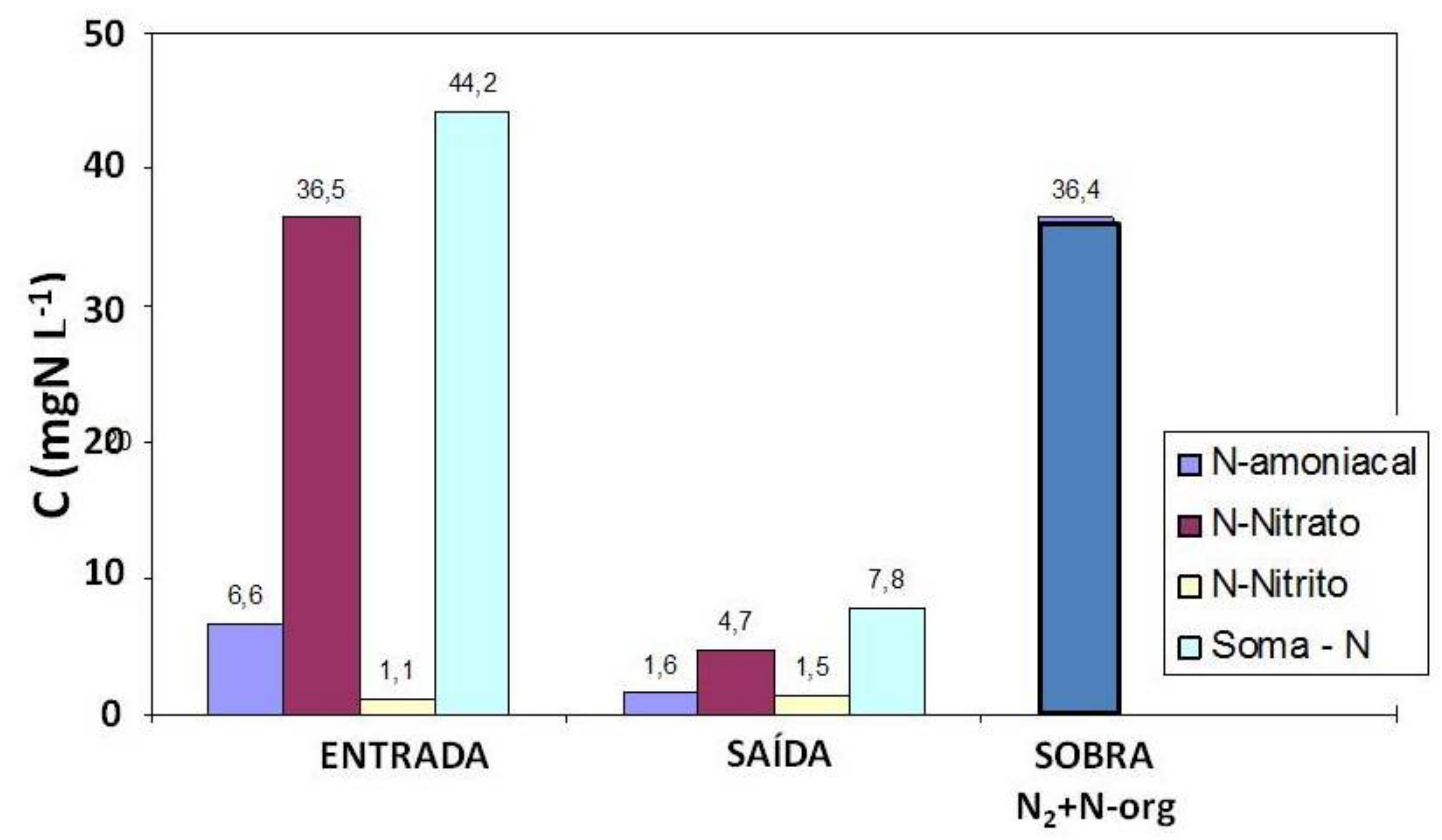

Figura 46: Balanço de massa para os compostos de nitrogênio durante a condição 2 de operação do RAALF 


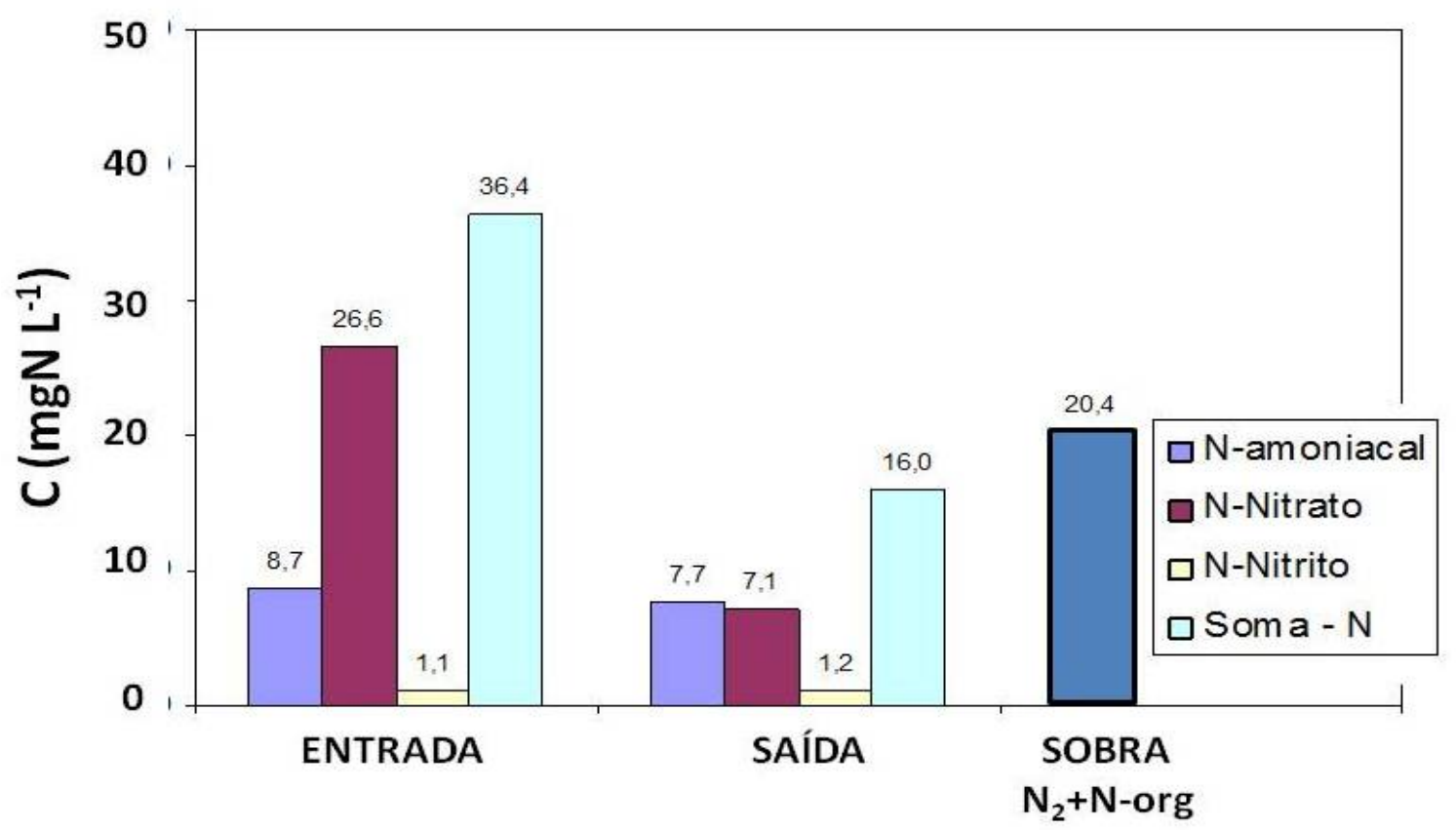

Figura 47: Balanço de massa para os compostos de nitrogênio durante a condição 3 de operação do RAALF.

É possível verificar que a concentração de nitrogênio na forma de nitrato na saída da câmara anóxica aumentou de $4,7 \mathrm{mg} \mathrm{N}-\mathrm{NO}_{3}{ }^{-} \cdot \mathrm{L}^{-1}$ na sub-condição 2.2 para $7,1 \mathrm{mg} \mathrm{N}-\mathrm{NO}_{3}{ }^{-} \cdot \mathrm{L}^{-1}$ na condição 3 , ou seja a desnitrificação foi menos efetiva na condição 3. A concentração de nitrogênio na fase líquida provavelmente convertida a nitrogênio gasoso foi de $20,4 \mathrm{mg} \mathrm{L}^{-1}$ nesta condição, valor inferior ao da sub-condição 2.2 que foi de $36,4 \mathrm{mg} \mathrm{L}^{-1}$. Valores da taxa de desnitrificação corroboram esses dados,pois na sub-condição 2,2 a média da taxa de desnitrificação foi de $178 \pm 43 \mathrm{~g}-\mathrm{N} \mathrm{m}^{-3}$ dia $^{-1}$, enquanto que na condição 3 diminuiu consideravelmente para $44 \pm 50 \mathrm{~g}-\mathrm{N} \mathrm{m}^{-3} \mathrm{dia}^{-1}$.

Isso provavelmente foi provocado primordialmente pela queda da concentração do aceptor de elétrons nitrato e não pela mudança na concentração do biogás nestas fases. Os resultados deste balanço mostram que a disponibilidade de nitrato diminui na condição 3 em comparação com a subcondição 2.2 , passando de 36,5 para $26,6 \mathrm{mg} \mathrm{N}-\mathrm{NO}_{3}{ }^{-} \cdot \mathrm{L}^{-1}$. Isto se deveu primordialmente à queda da eficiência na oxidação de nitrogênio amoniacal na condição 3, com aumento da concentração de 6,6 para $8,7 \mathrm{mg} \mathrm{N}-\mathrm{NH}_{4}{ }^{+} \cdot \mathrm{L}^{-1}$ na sub-condição 2.2 e na condição 3, respectivamente. Com menor 
disponibilidade de aceptor de elétrons, menor a taxa de desnitrificação considerando que mesma a vazão foi aplicada nestas etapas.

\subsection{ESTUDOS MICROBIOLÓGICOS}

\subsubsection{NÚMERO MAIS PROVÁVEL}

O crescimento das bactérias nitrificantes e desnitrificantes foi acompanhado por meio da determinação do NMP. Na Tabela 18, podem ser observados os resultados obtidos neste ensaio.

Tabela 18: NMP de bactérias nitrificantes, desnitrificantes e metanotróficas de amostras retiradas das câmaras aeróbia e anoxica do RAALF durante a operação

\section{NMP.gSTV}

\begin{tabular}{|c|c|c|c|c|c|c|}
\hline \multirow{2}{*}{ ETAPA } & \multicolumn{3}{|c|}{$\begin{array}{l}\text { Amostras retiradas } \\
\text { da câmara aeróbia }\end{array}$} & \multicolumn{3}{|c|}{$\begin{array}{l}\text { Amostras retiradas } \\
\text { da câmara anóxica }\end{array}$} \\
\hline & NITRI & NITRA & METAN & $\begin{array}{l}\text { DESNIT } \\
\text { TOTAIS }\end{array}$ & $\begin{array}{l}\text { DESNIT } \\
\text { AUTO }\end{array}$ & METAN \\
\hline 1 & $2,5.10^{7}$ & $3,1.10^{6}$ & $2,2.10^{3}$ & - & - & - \\
\hline $2(2.2)$ & $2,2.10^{7}$ & $3,0.10^{6}$ & $2,5 \cdot 10^{3}$ & $5,2.10^{10}$ & $4,2.10^{7}$ & $1,8.10^{3}$ \\
\hline 3 & $2,0.10^{6}$ & $2,2.10^{5}$ & $3,2.10^{4}$ & $4,8.10^{9}$ & $4,0.10^{5}$ & $2,5.10^{4}$ \\
\hline
\end{tabular}

Legenda: NITRI: Nitritante; NITRA: Nitratante; METAN: Metanotrófica; DESNIT TOTAIS:

Desnitrificantes Totais; DESNIT AUTO:Desnitrificantes autotróficas

Os resultados obtidos a partir do ensaio de NMP confirmam a maior presença de populações responsáveis pela oxidação do nitrogênio amoniacal que de bactérias responsáveis pela oxidação de nitrito. Tal fato é explicado pela maior produção de energia advinda da nitritação $(350 \mathrm{~kJ})$, em comparação com a nitratação $(150 \mathrm{~kJ})$. Tais resultados corroboram a hipótese admitida como a verdadeira para o processo de nitrificação. 


$$
\begin{gathered}
2 \mathrm{NH}_{3}+3 \mathrm{O}_{2} \rightarrow 2 \mathrm{NO}_{2}^{-}+3 \mathrm{H}^{+}+2 \mathrm{H}_{2} \mathrm{O} \\
\Delta \mathrm{G}^{0}=-384 \mathrm{~kJ} \\
\text { Equação } 32 \\
2 \mathrm{NO}_{2}^{-}+\mathrm{O}_{2} \rightarrow 2 \mathrm{NO}_{3}^{-} \\
\Delta \mathrm{G}^{0}=-152 \mathrm{~kJ} \\
\text { Equação } 33
\end{gathered}
$$

Também foi possível detectar a presença de organismos metanotróficos na câmara aeróbia em todas as etapas do trabalho, o que suporta a hipótese de que a câmara aeróbia funcionou efetivamente na oxidação do metano a dióxido de carbono, sendo possível verificar que, na condição 3, justamente quando a eficiência de remoção de metano aumentou consideravelmente, houve um incremento em uma ordem de grandeza no NMP das bactérias metanotróficas.

O NMP de bactérias desnitrificantes revelou quantidade expressiva destes microrganismos, pois foram obtidos valores muito maiores que os apresentados para as bactérias nitrificantes. Com relação aos microrganismos desnitrificantes autotróficos presentes na câmara anoxica, é possível verificar que, durante a condição 2, quando o sulfeto foi aplicado em excesso no reator, o NMP do grupo de microrganismos desnitrificantes autotróficos esteve duas ordens de grandeza acima do que quando a concentração de sulfeto aplicada foi drasticamente diminuída.

O NMP dos microrganismos metanotróficos realizado com amostras retiradas da câmara anóxica revelaram que houve um aumento em uma ordem de grandeza na condição 3, em comparação com a condição 2 .

Esses valores contrastantes entre os microrganismos autotróficos desnitrificantes e os organismos metanotróficos pode ter ligação com a mudança na concentração do biogás entre as duas etapas, uma vez que a concentração de sulfeto foi reduzida em 100 vezes, enquanto que a concentração de metano foi mantida no mesmo patamar na condição 3 em relação à condição 2 . 


\subsubsection{ATIVIDADE DESNITRIFICANTE}

A Tabela 19 apresenta os resultados obtidos a partir dos ensaios de atividade desnitrificante das amostras retiradas do reator, durante as condições 2 (sub-condições 2.2.) e 3 de operação. Conforme relatado na literatura (Reyes-Avila et al., 2004) existem indícios de que a desnitrificação ocorre mais facilmente pela utilização de compostos de enxofre do que pelo uso do metano, não só em virtude de características químicas (solubilidade do gás), como bioquímicas (uma das rotas para a produção de metano exige a cooperação entre dois grupos de bactérias: heterotróficas e metilotróficas).

Para tentar inferir qual foi o doador de elétrons preferencial utilizado na desnitrificação, foram retiradas amostras do reator para análise da atividade desnitrificante.

Tabela 19: Atividade desnitrificante durante a operação do RAALF gN.(gSVT.d) $)^{-1}$

\begin{tabular}{cccc}
\hline \multirow{2}{*}{ Condição } & & Substratos & \\
& Metano & Sulfeto & Acetato \\
\hline $2(2.2)$ & 0,16 & 0,57 & 0,18 \\
3 & 0,27 & 0,11 & 0,05 \\
\hline
\end{tabular}

Os resultados obtidos indicam que a desnitrificação com metano pode ser tão ou mais efetiva do que a desnitrificação com acetato (o composto orgânico utilizado nestes ensaios). Durante a subcondição 2.2 da condição 2 , os valores de atividade desnitrificante praticamente foram os mesmos para estes dois doadores de elétrons, indicando que, mesmo sob condições de alta concentração de doador sulfeto de hidrogênio, provavelmente houve a utilização efetiva do doador de elétrons metano, e que os microrganismos também poderiam estar consumindo doador de elétrons heterotrófico. Os resultados obtidos nestes ensaios com amostras retiradas durante a sub-condição 2.2 para o doador sulfeto de hidrogênio foram bem mais elevados, se comparado com os outros doadores. A aparente preferência pelo uso de $\mathrm{H}_{2} \mathrm{~S}$ em detrimento ao $\mathrm{CH}_{4}$ pode ser devida ao fato de que a utilização de compostos 
reduzidos de enxofre na desnitrificação é mais favorável que a utilização do metano, pois o $\Delta \mathrm{G}^{0}$ é pelo menos quatro vezes menor para reações com o sulfeto em relação ao metano para uma mesma quantidade de nitrogênio reduzido (Reyes-avila et al., 2004).

Durante a condição 3, com o decréscimo da concentração de sulfeto aplicada ao reator, a atividade desnitrificante com esse doador de elétrons decresceu consideravelmente de 0,57 para 0,11 gN.(gSVT.d) ${ }^{-1}$, enquanto que a atividade utilizando metano aumentou de 0,16 para 0,27 gN.(gSVT.d ${ }^{1}$ ), o que aponta para uma maior atividade do grupo de microrganismos metanotróficos. Interessante observar esses ensaios revelaram que na condição 3 houve queda na atividade de microrganismos com habilidade de utilizar compostos orgânicos. A atividade dos microrganismos que utilizam compostos orgânicos mais complexos que o metano decresceu para valores de 0,05 gN.(gSVT.d) ${ }^{-1}$. Este resultado levanta a hipótese de que, na condição 3 os microrganismos metanotróficos poderiam provavelmente estar realizando com mais eficiência a reação de redução do nitrato a partir do uso do metano, em condições de ausência de oxigênio livre.

\subsection{REFERÊNCIAS DO CAPÍTULO}

Abreu, S.A.; Zaiat, M. (2008) Desempenho de reator anaeróbio-aeróbio de leito fixo no tratamento de esgoto sanitário. Engenharia Sanitária e Ambiental. 13(2)

Barney, D.; Bliss, P. (1983) Biological control of nitrogen in wastewater treatment. E. \&F.N. Spon, London.

Beristain-Cardoso, R.; Sierra-Avarez, R.; Rowlette, P.; Flore, E.R.; Gomez, J.; Field, J.A. (2006) Sulfide oxiodation under chemiolitrothopic denitrifying conditions. Biotechnology and Bioengineering. 95(6), 1148-1157.

Carvalho, K.Q.; Salgado, M.T.; Passing, F.H.; Pires, E. C. (2008) Avaliação hidrodinâmica de Reator UASB submetido à variação cíclica de vazão. Engenharia Sanitária e Ambiental. 13(2), 226235.

De Nardi, I.R.; Zaiat, M.; Foresti, E. (1999) Influence of the tracer characteristics on hydrodynamic models of packed-bed bioreactors. Bioprocess Engineering. 21, 469-476. 
Domingues L.M.; Nour, E.A.A. (2005) Estudo Hidrodinâmico de um sistema combinado filtro anaeróbio - biofiltro aerado submerso. Anais do $23^{\circ}$ Congresso Brasileiro de Engenharia Sanitária e Ambiental. Campo Grande.

Dunn, I.J.; Heinzle, E.; Ingham, J.; Prenosil, J.E. Biological reaction engineering. Weinheim, VHC, 1992.

Environmental protection agency (EPA) (1975) Process design for nitrogen control. USA.

Garbossa, L.H.P. (2006) Avaliação de sistemas anaeróbio-aeróbio com biomassa imobilizada para remoção de matéria carbonácea e nitrogênio de esgoto sanitário e uso do biogás na desnitrificação. Tese (Doutorado) - Escola de Engenharia de São Carlos, Universidade de São Paulo, São Carlos.

Hanson, R.S.; Hanson, T.E. (1996) Methanotrophic bacteria. Microbiological Reviews. 60(2), 439-471.

Henze, M.; Harremoes, P.; Cour Jansen, J.; Arvin, E. (1997) Wastewater treatment biological and chemical processes. $2^{\mathrm{a}}$ Edição. Springer, 384p.

Houbron, E.; Torrijos, M. Capdevlile (1999) An alternative use of biogas applied at the water denitrification. Water Science and Technology. 40(8):115-122

Jimenez, B.; Noyola, A.; Capdeville, B.; Roustan, M.; Faup, G. (1988) Dextran blue colorant as a reliable tracer in submerged filters. Water Research. 22, 1253-1257.

Kos, P. (1998) Short SRT (solids retention time) nitrification process/flow sheet. Water science and technology. 38(1), 23- 29.

Levenspiel, O. (2000) Engenharia das Reações Químicas. Vol. 1 e 2, Edgard Blucher Ltda, São Paulo.

Lima, C.A.A. (2001) Tratamento de esgoto sanitário em reator anaeróbio horizontal de leito fixo (RAHLF) - Escala Piloto. Tese (Doutorado) - Escola de Engenharia de São Carlos, Universidade de São Paulo, São Carlos

Moraes, B.S. (2009) Utilização de sulfeto como doador de elétrons para a desnitrificação autotrófica aplicada ao tratamento de esgoto sanitário. Dissertação (Mestrado) - Escola de Engenharia de São Carlos, Universidade de São Paulo, São Carlos.

Oyarzún, P.; Arancibia, F.; Canales, C.; Aroca, G. E. (2003) Biofiltration of high concentration of hydrogen sulphide using Thiobacillus thioparus. Process Biochemistry, 1-6.

Rajapakse, J.P.; Scutt, J.E. (1999) Denitrification with natural gas and various new growth media. Water research. 33(18),3713-3734.

Rebhum, M.; Argaman, Y. (1965) Evaluation of hydraulic efficiency of sedimentation basis, ASCE. Journal of Sanitary Engineering. 91(5), p.37-45. 
Reyes-Avila, J.; Razo-Flores, E.; Gómez, J. (2004) Simultaneous biological removal of nitrogen, carbon and sulfur by denitrification. Water Research. 38, 3313-3321.

Stevens, D.K.; Berthouex, P.M.; Chapman, T.W. (1986) The effect of tracer diffusion in biofilm on residence time distributions. Water Research. 20(3), 369-75.

Sublette, K.L.; Kolhatkar, R.; Raterman, K. (1998) Technological aspects of the microbial treatment of sulfide-rich wastewater: A case study. Biodegradation. 9, 259-271.

Szwerinski, H.; Arvin, E; Harremoes, P. (1986) pH decreasing in nitrifying biofilms. Water research. 20(8), 971-976.

Thalasso, F. et al. (1997) The use of methane as a sole carbon source for wastewater denitrification. Water research. 31(1), 55-60.

Van Handeel, A.; Marais, G. (1999) O comportamento do sistema de lodos ativados. Campina Grande-PB. 472 pg.

Victoria, J.A. (2006) Filtro Biológico Aeróbio-Anóxico para remoção de nitrogênio de efluentes de reatores UASB. Tese-Doutorado. Escola de Engenharia de São Carlos, Universidade de São Paulo, São Carlos.

Visscher, A; Cleemput, O. (2003) Induction of enhanced $\mathrm{CH}_{4}$ oxidation in soils: $\mathrm{NH} 4+$ inhibition patterns. Soil biology and Biochemistry. 35, 907-913.

Zaiat, M.; Vieira, L.G.T.; Foresti, E. (1996) Liquid-phase transfer in fixed-bed of poliurethane foam matrices containing immobilized anaerobic sludge. Biotechnology techniques. 10(2), 121-126 


\section{Conclusões}

"O cientista não estuda a natureza porque ela é útil; ele a estuda porque se deleita nela, e se deleita nela porque é bela. Se a natureza não fosse bela, não valeria a pena ser conhecida, e se não valesse a pena ser conhecida, a vida não valeria a pena ser vivida" 
Através dos resultados obtidos com a operação do RAALF foi possível chegar às seguintes conclusões:

- Com relação à hidrodinâmica do reator:

- Os resultados dos ensaios hidrodinâmicos realizados permitem inferir que o RAALF possui padrão de escoamento que tende ao pistonado, sendo possível obter, nos ensaios realizados com dextrana azul, valores de $\mathrm{N}$ de até 14 reatores em série e $\mathrm{D} / \mathrm{uL}$ (baixa dispersão) de 0,09 para $\theta$ h de 5 horas - $\theta$ h considerado o mais adequado para operação do reator sob as condições experimentais estabelecidas. A influência das bolhas no padrão de escoamento no reator não foi significativa considerando a vazão de ar aplicada.

- Com relação ao monitoramento:

- A espuma de poliuretano ofereceu condições adequadas para a aderência e colonização de biomassa tendo apresentado boas características quanto à durabilidade, podendo, portanto, ser recomendada para este tipo de configuração de reator.

- O desenvolvimento da ampla gama de processos biológicos no RAALF ocorreu principalmente de uma forma seqüencial, tendo ocorrido a remoção da matéria orgânica e o processo de nitrificação, e posteriormente a desnitrificação. Porém, foi possível constatar, em determinados pontos do reator, a ocorrência simultânea de diversos processos, mas em menor escala.

- De maneira geral, foi possível obter considerável eficiência na remoção de matéria orgânica e nitrogênio. Sendo assim, o RAALF revelou ser uma unidade interessante para ser utilizada 
como unidade de pós-tratamento, pois alcança valores reduzidos de concentração dos compostos de nitrogênio.

- Não foi necessária a adição de alcalinizante no RAALF durante a condição 1, na qual operou sem a inserção de biogás sintético. Todavia, foi necessário fornecer alcalinizante externo a partir da condição 2, com o intuito de manter a estabilidade dinâmica dos processos de interesse no RAALF, principalmente devido a inserção de gás carbônico presente na mistura do biogás sintético.

- A desnitrificação mostrou-se viável, com indícios da coexistência da desnitrificação autotrófica e desnitrificação heterotrófica. As taxas de desnitrificação foram mais acentuadas nas subcondições 2.1 e 2.2, provavelmente devido ao fato de o sulfeto de hidrogênio ser fornecido em concentração pelo menos 100 vezes superior à da condição 3. Foi possível observar tanto a presença de grânulos de enxofre quanto a mudança na tonalidade da massa líquida no reator para um tom mais amarelado devido ao fornecimento de biogás sendo indicativo do uso de gás sulfídrico como doador de elétrons para a desnitrificação.

- O metanol foi o único composto intermediário detectado a partir da oxidação do metano, todavia somente durante a sub-condição 2.2 e de maneira inconstante. Todavia os resultados da atividade desnitrificante e do número mais provável indicam que o metanol poderia estar sendo produzido continuamente. Ademais, existe a possibilidade de o metano ser oxidado diretamente tendo o nitrato como aceptor de elétrons em condições anaeróbias, sem produção de intermediário. Estas duas situações poderiam estar ocorrendo simultaneamente no RAALF.

- Tanto o metano (remoção de até $61 \%$ ) quanto o sulfeto de hidrogênio (remoção de até 100\%) foram removidos do biogás, o que atesta a habilidade adicional do RAALF como uma unidade de tratamento de efluentes gasosos. Ressalta-se que a câmara aeróbia mostrou-se uma excelente unidade de polimento do biogás não utilizado na desnitrificação na câmara anóxica. 
- Com bases nos resultados obtidos a partir das análises microbiológicas foi possível constatar a presença de microrganismos - envolvidos com o ciclo do nitrogênio, do enxofre, além de bactérias metilotróficas - capazes de utilizar diversas substâncias como doadores de elétrons. Os resultados do número mais provável mostraram uma ampla gama de grupos de microrganismos presentes no RAALF, tanto na câmara aeróbia quanto anóxica, realizando os mais diversos tipos de processos, dentre eles a utilização de sulfeto de hidrogênio e metano tanto sob condições aeróbias quando anaeróbias. 


\section{Recomendações}

"A ciência nunca resolve um problema sem criar pelo menos outros dez."

George Bernard Shaw 
Com base na investigação realizada e nos resultados obtidos neste trabalho, sugere-se o estudo dos seguintes temas:

- Realizar estudos hidrodinâmicos após o término da operação do sistema para avaliar possíveis mudanças no padrão de escoamento em virtude do crescimento da biomassa.

- Testar outros materiais suporte para crescimento da biomassa;

- Avaliar o processo a partir da utilização de biogás real de reator anaeróbio tratando esgoto sanitário, com o emprego dos doadores de elétrons presentes no biogás;

- Utilizar os dados obtidos nos estudos hidrodinâmicos e nos perfis especiais deste trabalho para propor modelo cinético do RAALF;

- Identificar a população microbiana envolvida na gama de processos;

- Verificar a viabilidade do RAALF em escala piloto. 